\title{
A mathematical model to study reentrant cardiac arrhythmias
}

Citation for published version (APA):

Dassen, W. R. M. (1983). A mathematical model to study reentrant cardiac arrhythmias. [Doctoral Thesis, Maastricht University]. Rijksuniversiteit Limburg. https://doi.org/10.26481/dis.19830310wd

Document status and date:

Published: 01/01/1983

DOI:

10.26481/dis.19830310wd

Document Version:

Publisher's PDF, also known as Version of record

\section{Please check the document version of this publication:}

- A submitted manuscript is the version of the article upon submission and before peer-review. There can be important differences between the submitted version and the official published version of record.

People interested in the research are advised to contact the author for the final version of the publication, or visit the DOI to the publisher's website.

- The final author version and the galley proof are versions of the publication after peer review.

- The final published version features the final layout of the paper including the volume, issue and page numbers.

Link to publication

\footnotetext{
General rights rights.

- You may freely distribute the URL identifying the publication in the public portal. please follow below link for the End User Agreement:

www.umlib.nl/taverne-license

Take down policy

If you believe that this document breaches copyright please contact us at:

repository@maastrichtuniversity.nl

providing details and we will investigate your claim.
}

Copyright and moral rights for the publications made accessible in the public portal are retained by the authors and/or other copyright owners and it is a condition of accessing publications that users recognise and abide by the legal requirements associated with these

- Users may download and print one copy of any publication from the public portal for the purpose of private study or research.

- You may not further distribute the material or use it for any profit-making activity or commercial gain

If the publication is distributed under the terms of Article $25 \mathrm{fa}$ of the Dutch Copyright Act, indicated by the "Taverne" license above, 


\section{A Mathematical Model To Study Reentrant Cardiac Arrhythmias}

Proefschrift

Ter verkrijging van de graad van doctor in de geneeskunde aan de Rijksuniversiteit Limburg te Maastricht op gezag van de rector magnificus Prof. Dr. H.C. Hiemker, volgens besluit van het College van Dekanen in het openbaar te verdedigen in de aula van de Rijksuniversiteit, Tongersestraat 33 te Maastricht, op donderdag 10 maart 1983 des namiddags te vier uur precies.

door

Willem René Marie Dassen geboren te Maastricht. 
Promotor: Prof. Dr. Hein J.J. Wellens, Maastricht The Neherlands Prof. Dr. Rob M. Heethaar, Urrecht The Netherlands

Referenten: Prof. Dr. Harry A.J. Struyker Boudier, Maastrucht The Netherlands Frans J.L. van Capelle PhD, Amsterdam The Netherlands David L. Ross MB, BS, Sydney Australia

Het verschijnen van dit proefschrift werd mogelijk gemaakt door steun van de Nederlandse Hartstichting en Rescar (stichting ter bevordering van research in de cardiologie) Maastricht. 
To my parents

To Doortie 
Contents

Chapter 1.

Introduction

1.1 Historical overview

1.2 The philosophy behind the model

Chapter 2.

Description of the mathematical model

used to simulate clinical cardiac

electrophysiology

2.1 The model

2.2 The simulation study

2.3 The 35 different segment states

2.4 Order of handling

2.5 Handling of a segment without changes in electrophysiological parameters or new impulses

2.6 The introduction of a new impulse

2.7 Consequences of short refractory periods and non constant conduction velocity

Chapter 3.

Some simulation studies using the model

Chapter 4.

General discussion

4.1 Limitations

4.2 Accuracy

4.3 Real time application

4.4 Clinical applications

4.5 Didactical aspects

Chapter 5 . 
Chapter 6.

Appendix I : Handling of a segment

Chapter 7 .

Appendix II: Introduction of an impulse $\quad 89$

References

101

Slotwoord

107

Curriculum vitae 
"The great tragedy of Science-

the slaying of a beautiful hypothesis by an ugly fact"

T.H Hixley

(1823-1895)

Collected Essays 


\section{Chapter 1 .}

\section{Introduction}

\subsection{Historical overview}

In 1561, the noble Rutgerus of Randwick, mayor of Gennep, Holland, visited his physician Johann Weyer because of palpitations. Dr Weyer described the pulse of Rutgerus of Randwick as having an intermittent rhythm with every third beat a so-called "pulsus caprizans". (1)

Although at that time the interpretation of the pulse and the accompanying prognosis, as described by Galen (2) in the second century were still considered to be valid, Weyer recognised already, that the outcome of a disease not only depended on the characteristics of the pulse but also on the underlying condition of the patient.

Also for this patient, Weyer was right. Rutgerus did not die from his arrhythmia, but recovered after a copious evacuation. He was slain in 1583, murdered by a group of Spanish riders. (3)

Galen's interpretation of the pulse and its prognostic significance remained valid until the 17th century.

But Galen was not the first author interested in the arterial pulsations and their abnormalities.

Already in $500 \mathrm{BC}$. the art of feeling the pulse was known in China. Approximately in the year 280, a classic treatise on the pulse published in ten volumes was available in China. Roughly at the same time the "Pen tsao" (= System of Medicine) was published. In the sixih century it took Li Shi 30 years to compile it for publication. Using this method location and site of all diseases could be derived by studying the accompanying pulse. (4-5)

At the end of the 19 th century it was possible to record the mechanical pulse, and to register the electrical activity using the capillary electrometer. (6)

It was not until the beginning of the 20th century, that cardiac rhythm could be studied in a more easy and accurate way.

In 1906 Einthoven, professor in Physiology and Chancellor of the University of Leiden, presented at the occasion of the 331 st anniversary of the University his ideas about the use and the advantages of registration of the electrical activation of the hart with the help of the string galvanometer. Using this device he was able to make registrations of good quality. Referring to the fact that the patient in the hospital, and the cardiograph in his laboratory were connected over a long distance by telephone wires (1) the first registrations were named "Telecardiograms". At the same time Einthoven made some interesting remarks about the value of electrophysiological research and its relation to medicine. (7) He stated:

... physiology is no longer only pleasant entertainment, like the reading of a simple novel for a serious reader of scientific literature, but indeed an important and 
necessary subject of study...

The introduction of the recording of the electrical activity of the heart by a string galvanometer, was an important step on the long way to clinical electrophysiology of today.

In 1906 Einthower showed that by using different electrode positions potentials of different morphology could be recorded. He also gave examples of $2: 1$ atrioventricular block, extrasystoles, bigemnal rhythm and dextrocardia. In the same article he suggested the study of the influence of the administration of drugs on atrioventricular conduction. (3)

Athough the electrical registration of human cardiac activity was introduced in the begirning of this century, several decades passed before a more direct approach to the study of rhythm and conduction disturbances in the intact human heart became possible.

Important landmarks in the study of arrhythmias were the introduction of the recording of intra-cardiac potentials by Latour en Puech in 1957 ( 8 ) and the combination of intracardiac recordings coupled with programmed stimulation of the human heart by Durrer (10) in 1967. In that study the authors demonstrated in four patients with the WPW symdrome the initiation and termination of circus movement tachycardia by using properly timed electrical stimuli.

This was followed shortly thereafter by the development of a reliable catheter technique to record the His bundle electrogram in the human heart. (11)

The avallability of these intracardiac stimulation and recording techniques accelerated the accumulation of knowledge on conduction and rhythm abnormalities in man.

In 1971 Wellens (12) described the use of programmed stimulation of the heart in patients with atrial flutter, AV nodal tachycardia and the pre excitation syndromes. One year later he reported on the use of this technique in patients suffering from ventricular tachycardia. (13)

In patients sulfering from tachycardia clinical electrophysiological studies can be of great help in determining the underlying mechanism of the arrhythmia and the selection of treatment. (14)

These investigations however, are not without risks, relatively unpleasant to the patient, expensive, and time and personnel consuming. (15)

r.he study and understanding of mechanisms of tachycardias in patients using electrophysiological investigations is difficult because only limited data are available

- Most patients are investigated only a few times.

- The number of healthy volunteers to study impulse formation and conduction in the normal heart is almost nil.

- Many electrophysiological parameters are influenced by the autonomic nervous system. These changes are difficult to quantify and to control and canmot be reproduced at will. (16) 
Because of these limitations and also because of ethical reasons, it is impossible to perform certain studies in the intact human heart, like the effect of chronic drug intoxication on impulse formation and conduction. In such cases the use of an animal model can be of great help. Using such a model it is possible to repeat an experiment several times under well defined laboratory conditions. The fluctuations in sympathetic and vagal tone and their influences on electrophysiological parameters, are however very difficult to control in the intact animal model and extrapolation to the human heart is difficult.

To simulate electrophysiological experiments in a reproducible way, without spontaneous or autonomic fluctuations in any parameter, one can use a mathematical model.

This requires that the investigator describes all different parts of the model and defines the relations between them.

Following a mathematical description, the investigator can use actual values obtained during an electrophysiological study to test the effect(s) of various perturbations on the model. In such a model both the consequences of changes in parameters as selected by the investigator, and the effect of the introduction of extrastimuli can be studied.

By defining basic electrophysiological properties of the model and the induced changes, the investigator will be able to test hypotheses that originate during clinical electrophysiological investigations in man. Also multiple changes and combinations of changes in electrophysiological properties, which can not be investigated during the clinical stimulation study, can now be studied under defined circumstances. While attractive, computer simulation also has its limitations as will be shown later.

The use of a mathematical model to study electrophysiological properties of the heart is not new. Several models have been used to study aspects of cardiac electrophysiology, such as:

a) Basic cardiac electrophysiology (17 - 26)

b) Reconstruction of the electrocardiogram (27 - 41)

c) Simulation of the function of some parts of the conduction system of the heart $(42-45)$

d) The simulation of the total heart or parts of it, to study mechanisms, observed during clinical electrophysiological studies. $(46-50)$

\section{a) Basic cardiac electrophysiology}

Mathematical models have been developed to study the generation of impulses and their conduction to adjacent cells. Some of these models describe quantitatively membrane potentials, propagation of action-potentials and interference between two individual pacemakers. (17-23). Sharp for instance (20), combined numerical methods for solving cable equations and previously published models for membrane properties to simulate cardiac impulse propagation along a unidimensional strand. Decreased excitability and changes in intercellular 
coupling could be simulated. All these models were based on data from the cellular level derived from experiments using microelectrode techniques. The contribution by Hodgkin and Huxley (24) on mechanisms of impulse generation and propagation through a core-conductor model of propagation can be considered a standard work, forming the basis for several other models. in their work they introduced a model of an excitable cell on which the so-called HodgkinHuxley equations are based.

Recently van Capelle (25) published a study about impulse propagation in a twodimensional model. In this model sheets consisting of coupled excitable elements were used to simulate arrhythmias. Before simulation siarts the geometry of the network, the amount of coupling between elements and the electrophysiological properties of the elements, describing excitability, automaticity, and refractory period are defined. After defining the contour of the sheet of elements, using a joystick and a graphic display of the contour, elements can be removed, leaving holes in the sheet. In the same way connections between elements can be deleted, changed or added and the type of cells of the different elements can be modified. Using the same technique, the site of stimulation and the elements selected to be monitored on the terminal are determined. The activation of each element is recorded on a disk file for further interpretation. Using a sheet of these elements it was possible to simulate both focal and reentrant arrhythmias. "The author suggests that the spatial interaction could play an important role in this type of investigations.

It is of interest that many investigators describing impulse propagation concentrated upon intestinal tissue beside cardiac tissue because of its less complicated morphology as compared to the cardiac tissues. (26)

All models so far discussed, describe the heart in its basic state or allow the summation of a small. number of elements.

b) Reconstruction of the electrocardiogram.

One of the oldest models to reconsiruct the cardiogram was developed by Van der Pol in 1928. (27).

In 1965 Silvester showed in an analog model, that it was possible to simulate the vectorcardiogram. (28). To do so he divided the heart in 20 segments, each containing an independent time varying dipole. This model of a 20-dipole heart was located in an inhomogeneous volume conductor to simulate the torso. This was followed a few years later by a digital version. (29-30) Using these more powerful techniques the resolution was increased considerably. The Purkinje fiber distribution having homogeneous conduction velocity and the sites of first activation determined during animal experiments have to be given to the model. Myocardial lesions of $7-10 \mathrm{~mm}$ diameter and $2-3 \mathrm{~mm}$ thickness can be recognised in the simulated cardiograms.

In the model designed by Min in 1974, a matrix of relaxation oscillators coupled in two directions was used to describe the electrical activity in smooth muscle like stomach and small intestine. To describe these oscillators a group of non-linear differential equations were applied. This made it possible to simulate the normal 
electrocardiogram, some arrhythmias and the use of an external pacemaker. (31) Also in the model of Rosenberg one is able to simulate a number of arrhythmias. (32)

In many of these models designed to reconstruct the surface electrocardiogram, special attention is given to the influence of size and shape of the thorax on the configuration of the electrocardiogram. $(33-41)$.

In 1978 Miller presented a digital model for the simulation of body surface electrocardiograms during the ventricular activation and recovery (33) Using approximately 4000 elements in a three dimensional array, a reconstruction of the ventricles of the heart was made. These 4000 elements were grouped into 23 regions. Data about the excitation sequence and the action potentials were taken from the literature. By summing up all potentials in each region the dipole representing that region can be calculated. By combining these 23 dipoles and assuming the heart to be surrounded by a homogeneous volume conductor with the shape of an adult male torso, the potentials on the surface could be simulated In the same issue of Circulation Research Miller described the simulation of ischemia and infarction (34) This was based on the hypothesis that ischemia is reflected by a decrease in the magnitude of the resting potential and changes in action potential duration. By progressively modifying the action potentials in those elements representing the area of ischemia, the electrocardiographic signs of ischemia could be simulated.

Anterior and inferior transmural ischemia and infarction and anterior subendocardial ischemia could be simulated.

Based on the assumption that the ventricles (apart from the septum) have a eccentric spherical configuration, Hori (35) developed a mathematical model of the activation of the ventricles. Like others he divided the ventricle in a number of small elements each containing one dipole. To calculate the behaviour of every dipole data derived during animal experiments were used. In this model a few limitations are present. 1) There is no intraventricular septum. 2) The eccentrical spherical model does not duplicate the morphology of the ventricles satisfaciory.

3) The conduction velocity in the conduction system and the myocardium is assumed to be constant.

In the model constructed by Ritsema van Eck (37) a much more accurate representation of the morphology of the two ventricles was given.

In this 3-dimensional model the ventricle was reconstructed using 155000 regularly packed rhombododecahedragonal cells, each whith a volume of $1.28 \mathrm{~mm} 3$. The endocardial surface was covered by a network of Purkinje cells. Each myocardial cell was assumed to be at rest, activated or refractory. The time delay between the activation of adjacent cells represent the conduction velocity. Also in this model laboratory data were used to determine the first sites and times of activation.

In the study of Rudy and Plonsey (38) special emphasis was given to the influence of variations in the location of the heart on the potentials measured at the epicardium. The effect of the surface layer and subcutaneous fat on these potentials was shown to be minimal. In a second study the author(40) used this model of eccentric spheres to determine the influence of a number of factors on the electrocardiogram. They studied the influence of the blood pool on these potentials. 
anemia and polycythemia. Low lung conductivity (emphysema), low and high pericardial and myocardial conductivity was simulated and the infuence on the electrocardiogram was studied. The influence of low skeletal muscle conductivity. obesity, a thick myocardium protruding into the lung region, increase of myocardial wall at the expense of the blood cavity and finally the position of the heart in the torso was determined.

Ramsey (41) simulated the surface electrocardiogram using potentials directly measured on the epicardial surface instead of using a number of dipoles. To do so 90 electrodes were chronically implanted on the ventricle. Heart to body surface transfer coefficients were derived from the measured geometric coordinates of all the electrodes, assuming a homogeneous volume conductor between the epicardium and the body surface.

In the study by Arntzenius et al (36) several different models designed to reconstruct the heart are discussed.

c) Simulation of the function of some parts of the conduction system of the heart

These models are developed to describe and investigate the function of parts of the cardiac conduction system.

In 1971 Omera made an analog model of the conduction in cardiac tissue, using a tunneldiode. (42)

This was followed in 1973 by a mathematical description of conduction through the AV Node by Heethaar. (43) To analyse AV nodal conduction an isolated. perfused rat heart was stimulated using a variety of impulse sequences such as fixed rates and frequency steps. The responce was measured on the left ventricular epicardium. Using these data a mathematical description of the AV node was determined. By stimulating the atrium at a random cycle length, which was longer than the AV nodal refractory period, the ventricular response was determined and compared with the mathematical model. It was shown to be possible to determine the atrial cycle length or the AV nodal conduction time from the ventricular cycle length. After including the influence of refractoriness in the behaviour of the model the influence of blocked impulses can be studied. It appears that the influence of a blocked impulse and a conducted impulse on the conduction time can be calculated using the same mathematical equations. In this model Wenckebach conduction can be demonstrated. The same author also constructed an analog model of $\mathrm{AV}$ nodal conduction to find a physiological explanation for the mathematical relationships found during $A V$ nodal conduction (44-45). A transmission line of coupled excitable cells was used obeying the Bonhoeffer-Van der Poll equations. The reaction of the transmission line on fixed rates of stimulation and frequency steps was compared with the behaviour of the AV node in animal experiments.

d) Simulation of the total heart or parts of it, to study mechanisms observed during clinical electrophysiological studies

Only in this group of mathematical models mechanisms of arrhythmias and relevance of clinical observations can be studied.

In these models the conduction system or parts of it have been simulated. This allows testing of hypotheses from clinical electrophysiological investigations. 
To simulate the whole heart one camnot use a model based on a description of impulse propagation between cells. Such a model would be enormous because millions of coupled oscillators have to be taken into consideration. Furthermore during clinical electrophysiological investigations the properties of these cells are not known.

In 1982 Holley used a 3-dimensional model of the ventricles to simulate ventricular tachycardia. (46)

Our group has previously reported on the use of a mathematical model to study factors influencing stability of a circus movement tachycardia. (47-48) During an invasive electrophysiological investigation in a patient a characteristic pattern of termination of a circus movement tachycardia was observed. Using data on A.V nodal conduction ${ }_{*}$ a single purpose model to study this alternation of the tachycardia cycle length prior to termination, was constructed. The findings using this model were compared with the clinical data. Both were in complete agreement. These results were used to verify the behaviour of the model described in this thesis. Using a mathematical model, we also described that some of the criteria advanced as diagnostic for triggered activity as mechanism of a tachycardia, can also be observed in arrhythmias using a reentry circuit. (49)

A major problem with investigations using mathematical models is the need to design a completely new model for every simulation study because new components of circuits involved in conduction of impulses have to be used. It is of interest that all these mathematical models have some parts in common.

To make simulation studies available to a larger field of users, a general model of electrical conduction through the heart was designed.

The specifications and properties of such a model are described in this thesis. The limitations of such a general simulation model will be discussed also.

\subsection{The philosophy behind the model}

The aim of this study was to develop a mathematical model to facilitate research in clinical electrophysiology. We therefore wanted to have a model whose structure and components would allow implementation of data derived from clinical studies

Invasive electrophysiological investigations can be performed for different reasons.

1) To localize the site of the abnormality in the conduction system in patients with conduction disturbances.

2) To study the mechanisms of tachycardias.

3) To select the best medication to protect the patient against the recurrence of arrhythmias.

4) To increase our knowledge of the 12 lead electrocardiogram by correlating findings from electrophysiological investigations with the surface electrocardiogram.

In our department clinical electrophysiologal investigations are performed as follows: 
Ater local anaesthesia, the femoral ven is punctured and catheters are introduced percutaneousy and positioned in the heart under fluoroscopic control. The following locations of the catheter are most often used: 1) the high right atrium, 2) across the tricuspid valve ning to record His bundle electrograms, 3) the coronary sinus to record and stimulate the left atrim, 4) the apex of the right ventricle. To record and stmulate the left ventricular apex, the catheter is introduced retrogradely to the left ventricle using the femoral artery or using a transseptal approach in patients with a patent Ioramen ovale. Cathelers are used for recording the local activity and to deliver electrical stimuli. By using tri-or quadripolar catheters stimulation and registration from one site can be performed simultaneously.

By recording activation times from the different catheters conduction times between the different sites of the heart can be determined. These measurements of conduction times are pertormed during sinus rhythm and during pacing at different cycle lengths. The relation beween heart rate and conduction time can be studied. Using a basic paced rhythm and one extra stimulus, the refractory period of the different parts of the conduction system of the heart can be determined. By using different sites and different stimulation cycle lengths initiation and termination of tachycardias is studied and the influence of medication on arrhythmias evaluated. During the investigation all signals are recorded simultaneously and continuously on 16 channel paper and stored on tape. The paperspeed used (100 mm/s) gives a measurement accuracy of $51010 \mathrm{~ms}$.

During these electrophysiological investigations information of the electrophysiologic properties of the heart at the cellular level does not become available. Also knowledge about the exact topographical and morphological aspects of the conduction system in the patient under study cannot be obtained. This makes it impossible to reproduce the activation of the heart in a way as done in the Ritsema van Eyk model.

Furthermore information about the electrophysiological properties of the intact human heart is limited, because the number of sites of observation using intracardial catheters has to be restricted for practical reasons.

As described, by using catheter techniques one can obtain information aboul conduction belween different sites of the heart. It gives values on conduction velocily and the duration of refractory period of tissue in between the sites of the diferent calhetertios.

In general: to be useful our model should fullil the following criteria:

- It should resemble reality as closely as possible, especially in relation to stimulation studies performed in the intact human heart.

- It should be based on a modular concept. This will enable flexibility both in the layout of the conduction pathways, as in the electrophysiological properties of these pathways.

- The behaviour of the model should be logical and understandable. 
- Results should be presented in a uniform way, at an acceptable computing speed.

The model described in this thesis has to fulfill the following extra requirements:

- Only data should be used that can be derived from invasive electrophysiological investigations. Not in the first place to be able to reproduce the activation in each patient who undergoes electrophysiological investigation, but to be able to test hypothesis derived from finding during these studies.

- The model should be applicable without special knowledge about handling computers. The program has to collect all input data in a ergometric way. This input of data and the resulting output of results should be performed using a syntax understandable for clinical electrophysiological investigators.

By constructing the model in this way, not using coupled oscillators (which properties cannot be determined during invasive electrophysiologic investigation) all these conditions can be fullfilled.

Approaching the study of reentry arrhythmias using network analysis techniques makes it possible to translate clinical hypotheses directly in o computer language

In the development of this mathematical model a number of assumptions have been made of which some cannot be tested and other apparently are made arbitrarily. For example the assumed homogenity of different segments, the absolute refractoriness of an element, (an element is refractory or excitable, there is no state inbetween), the selection of a simulation cycle length of $1 \mathrm{~ms}$ and the subdivision of a segment in 100 elements. In this thesis a rationale will be given at the time of making these assumptions.

In the model only tachyarrhythmias on the basis of reentry will be simulated. Other mechanisms of arrhythmias like parasystole can be simulated in the model. but only as an independent source of impulse formation. 


\section{Chapter 2.}

\section{Description of the mathematical model used to simulate clinical cardiac electrophysiology}

2.1 The model

2.2 Simulation studies

2.3 The 35 different segment states

2.4 Order of handling

2.5 Handling of a segment without changes in electrophysiological parameters or new impulses

2.6 The introduction of a new impulse

2.7 Consequences of short refractory periods and non constant conduction velocity

\section{1 The model}

As mentioned in chapter 1 the structure of the mathematical model is based upon observations obtained during invasive clinical electrophysiological studies in man.

During these investigations catheters are introduced into the heart at a number of sites. At these sites the intracardiac electrical activity is recorded and programmed electrical stimulation performed to study conduction between different parts of the heart and the mechanisms of tachycardias.

With the information obtained by these techniques, one can design a network, built of segments, in which the segments represent the pathways between different sites in the heart. In this network we assume that the impulse is able to propagate along the different segments in only anterograde, retrograde, or both directions.

Segment properties depend on the electrophysiological data, measured with help of the catheters. "The junctions between the different segments in our model represent the catheter positions used in the patients.

This approach allows the implementation of observations from electrophysiological studies into a mathematical network.

By using information about the electrophysiological properties of the segments in between two junction points as obtained during programmed stimulation of the heart values from clinical electrophysiological studies can be put into the model. 
Fig 2.11. gives an example from a patient with the Wolf-Parkinson- White syndrome having a left sided accessory pathway between the atrium and the ventricle.

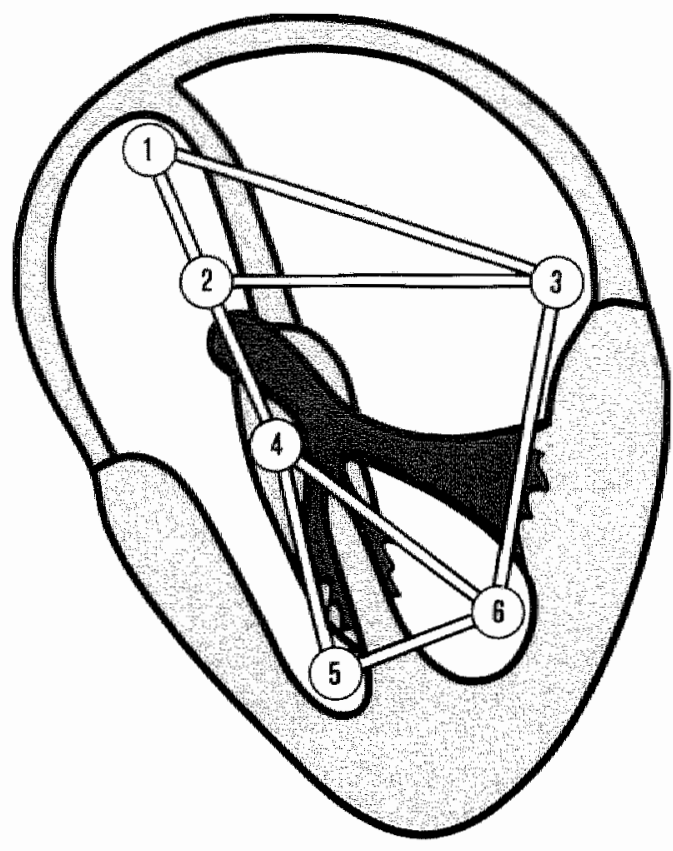

FIGURE 2.1.1.

Legend to figure 2.1.1

This figure is a schematic drawny of the heart and is conduction system. As shown there are six uncton ponts. representng the catheter postions (open circles) used during the efectrophysiological investgation The segrnents are localed between the junction points. indicatng that conduchon between these ponts in at deast

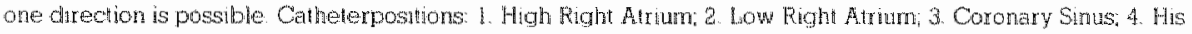
Bunde region; 5 . Righ Ventricle; 6 . Left Ventricle. Note that on the left side of the heart an accessory pabway is present enabling conduction besween atrim and ventricle over tha structure.

\section{Definitions}

Conduction time in one segment: the time required for an impulse to travel through a segment from one junction point to the next one. These times can be related to the cycle length of the last cycle (so called rate-dependency).

The refractory period of a segment is the longest time interval between two successive impulses during which the second impulse is unable to penetrate into a segment in the same direction.

In the model described hereafter a segment can either be excitable or refractory. No intermediate possibility exists in this model.

In clinical electrophysiology it is very difficult to differentiate between the partially refractory and the complete refractory state. Since the model is only using data that can be derived during these clinical studies, the relative refractory phase has been ignored and only two states are accepted: refractory or excitable.

The segments of the model have homogeneous electrophysiological properties which do not change during the conduction of an impulse through the segment. This does not mean that each impulse through the segment has the same conduction 
time or that the segment has always the same refractory period. Both can be changed for example in relation to the rate of impulses going through the model. During conduction through a segment, however, the conduction velocity is considered to be constant.

Although it is rather unlikely that all electrophysiological parameters are distributed homogeniously over a segment, there is no better information available The properties of a segment, derived during electrophysiologic investigations are also determined over the whole segment independent of the actual distribution of these properties.

The conduction velocity and the refractory period are defined in anterograde as well as in retrograde direction. This is done because electrophysiological properties of parts of the cardiac conduction system can be, and frequently are, different in anterograde and retrograde direction.

Unidirectional block in a segment is represented in oux model by inability 10 conduct in one direction. If unidirectional block would have been represented by extremely slow conduction through a segment, permanent block occurs in the direction opposite to conduction.

An impulse travelling through a segment is followed by a refractory sector. The length of this refractory sector is determined by the time of activation of the first element, the conduction velocity in the segment and the duration of the refractory period. The first activated element is the first one to be excitable again after termination of the refractory period. After a certain period of time following activation of an element, not all elements within a segment will be refractory. The elements activated first can again be excitable. The elements which at a certain time interval are still inexcitable are considered to form a tail of refractoriness.

As soon as the first element becomes excitable again the refractory or excitable state of the segment is defined by the position of the tail. In the same direction, impulse and tail travel with the same velocity.

To define the position of the impulse and the tail, each segment is divided into 100 elements. Element $\mathrm{I}$ is the first element used when an anterograde impulse is conducted through the segment. During retrograde conduction element 100 is the first one activated. When an anterograde impulse has reached or passed the element 100, the impulse is considered to have left the segment, leawing behind a certain number of refractory elements.

The subdivision of a segment in 100 elements is arbitrary. By increasing the number of elements the accuracy will only increase if the simulation cycle length decreases with the same magnitude. This procedure will increase computing time. More information on the relation between computing time and resolution is given in paragraph 4.2 .

Another important concept of the model is the collision point. If an anterogradely and a retrogradely conducted impulse collide, the collision point within the segment is calculated. This calculation is made by taking into account the old positions of the impulses together with the conduction velocities in both directions.

Usually at both sides of the collision point a part of the segment is refractory. "The 
collision point is always the last activated element of a segment. and the last one 10 become excitable again.

Conduction velocities are defined as the number of elements in a segment (100). divided by the conduction imes in ms. Conduction velocity is defined both in anterograde (AV) and retrograde (RV) direction.

Conduction distances in each direction are defined as the mumber of elements passed by an impulse during one simulation cycle, (see below) in each direction. They are also defined anterogradely (AD) and retrogradely (RD).

In the model simulation cycle lengths of $1 \mathrm{~ms}$ have been selected arbitrarily. Longer cycle lengths to increase simulation speed, or shorter cycle lengths to increase temporal resolution are possible however.

The best resolution achieved using registrations on paper is 5 till $10 \mathrm{~ms}$. Using a simulation cycle length of $1 \mathrm{~ms}$ the model is always more accurate then these registrations

\section{Segment states.}

Every segment is defined by its state and the value of its parameters. In figure 2.1.2. a schematic representation of a segment is presented. An impulse is penetrated in the anterograde direction.

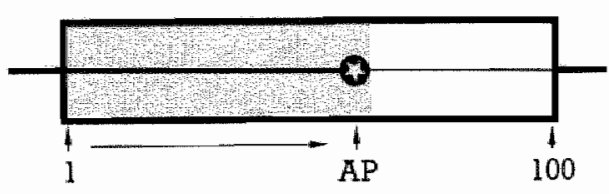

8 AP

FIGURE 2.1.2.

Legend to figure 21.2

Thu floure shows a segment wh an anterogradely partially conducted impulse. The pastion of the mpulse (Ap) is

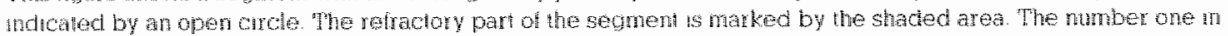

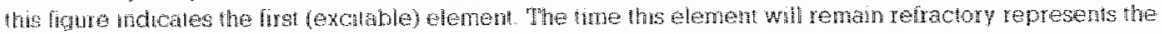
refractory state of the segment afler a conducted inpulse

AP indicates the position of the impulse in the segment. If the impulse is located at position no 1 , it means that the impulse has just entered the segment. If the impulse reaches position 100 , or passes it the impulse is considered to have left the segment and the value of $\mathrm{AP}$ returns to zero. An AP value of zero indicates therefore that no impulse is being conducted through the segment.

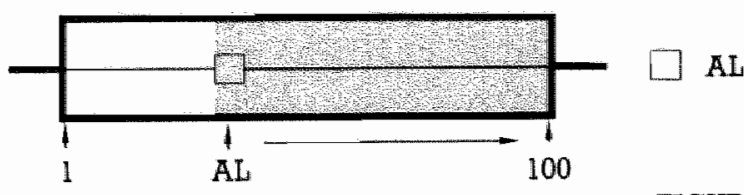

FIGURE' 2.1.3.

Legending tome 21,3

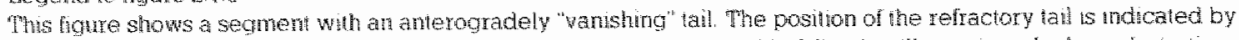

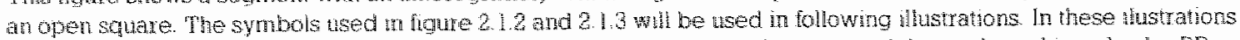
a colision point (CP) whl be indicated by a back circle, the position of a retrogradely conducted unpulse by tap and the renograde vanishing tail by $\mathrm{RL}$. 
As soon as the time for refractoriness at the first excitable element has returned to zero, some elements will become excitable again during the next simulation cycle. The $A L$ (Anterograde taiL) represents the end of the refractory tail after conduction of an impulse. It is processed in the same way as an impulse is processed.

\section{Simulation studies}

A simulation study contains the following five parts.

1) Defining the network.

The site and number of junction points are selected. The segments, representing pathways, are located between these junction points.

2) Defining the electrophysiological properties of the segment. The properties of the segments are defined, including: conduction velocity, refractory period and ability of an impulse to be conducted into one or both directions.

3) Defining the initial state. If at the start of the simulation study the network is not conducting impulses and no segment is (partially) refractory, all segments are in state 1. (see paragraph 2.3).

4) The actual computation.

During the simulation process a certain sequence of operations is continuously repeated.

a) The first operation is the calculation of the state of each segment after one more cycle. To calculate the new state, the present state and electrophysiological properties of the segment are considered. The different possibilities are described in detail in paragraph 2.5 .

b) In the second step the introduction of an impulse into a segment is considered. This impulse can be conducted from one segment to a junction point and from there into all the segments that are connected to that junction point. The impulse can also be entered over a free end of a segment, that means a junction point connected to one single segment. Before an impulse can enter a segment a number of conditions have to be fulfilled. In paragraph 2.6 these conditions are listed.

c) In the third step the model tests whether or not the electrophysiological properties of one or more of the elements have changed. "The possible consequences of a change in electrophysiological parameters are listed in paragraph 2.7 .

5) Presenting the results.

Results can be presented in three different ways:

a) The time of activation of a junction point is given, together with the number of the segment which was conducting this impulse. Also when applicable the occurrence of a collision point is reported. This enables the user to draw ladder diagrams of activation through the conduction system. 
b) After every compulational cycle (or a mulpple of cycles) all parameters of one or more segments can be printed. This makes it possible to study very accurately the behaviour of a part of the conduction system. The amount of data, however, is too big lo use this method over a long period of lime.

c) In special circumstances it is possible to represent the defined nework on a high-resolution graphic display. The position of impulses, tails and collision points can be displayed realistically. The amount of work required however, limis this application only to didactical purposes.

\subsection{The 35 different segment states}

Considering the definitions and limitations as described in detail in paragraph 2.7. only 35 different states of a segment are required to define the possible stales of a segment. These states (ST) will be described in more detal below. By limiting the number of states to 35 , the structure of the model remains simple and computer time can be reduced.

(1)

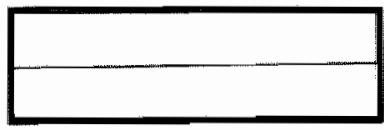

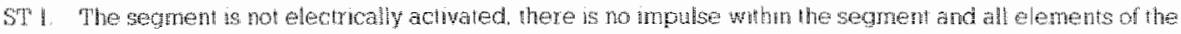
segment are exclable. The segment is able to conduct the next tmpulse.

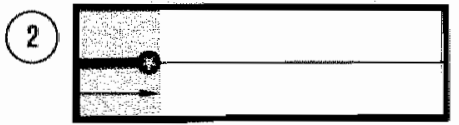

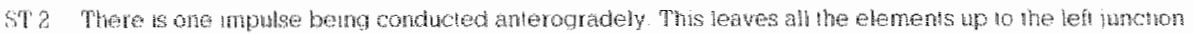

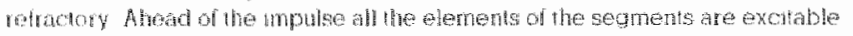
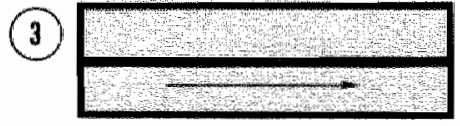

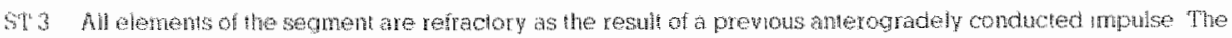

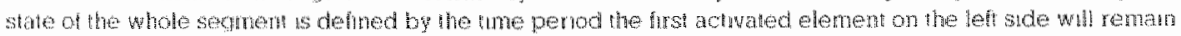
rematis.
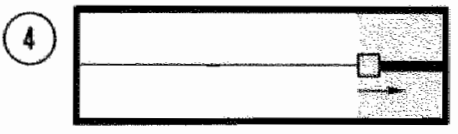

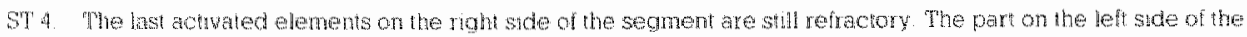

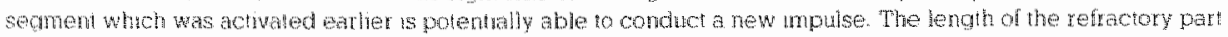
of the stoment is detmed by the position of the tat in the segment 


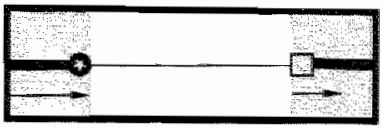

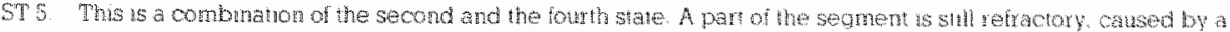

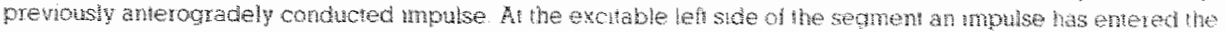

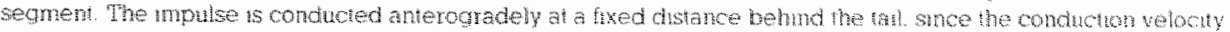
of the mpulse and the tal are constered bo bual

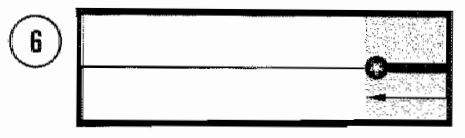

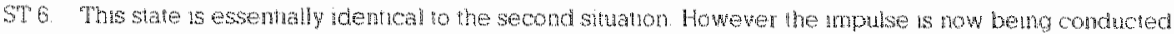
retragradely through the segmert.

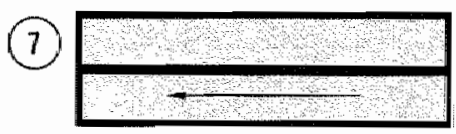

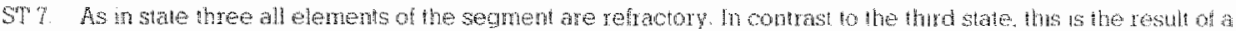
prevnously renogradely conducted irmpulse.

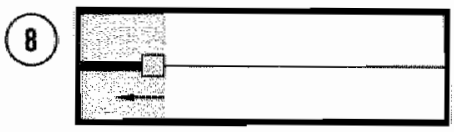

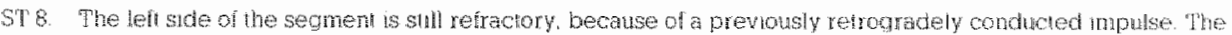

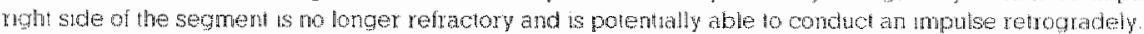

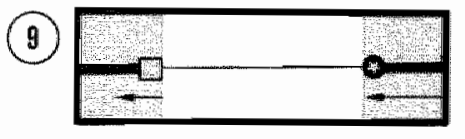

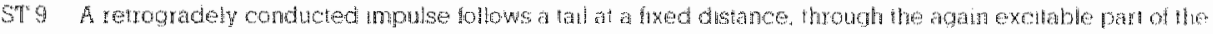
segment on the nohn wade

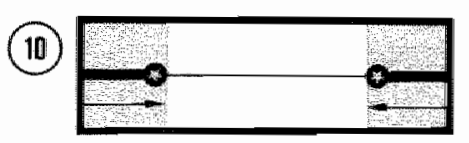

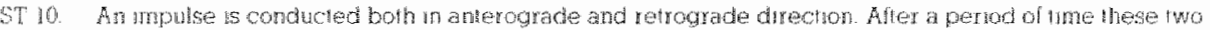

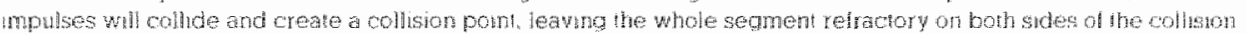
point 


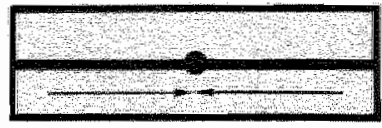

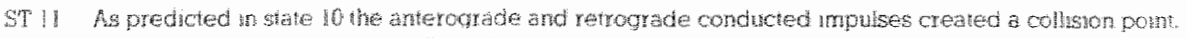

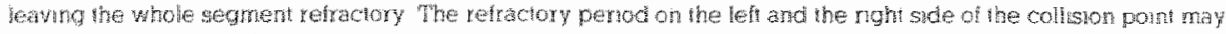
of mat not be equal no tength

(12)

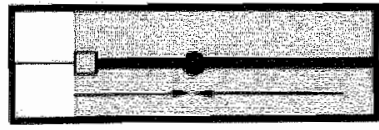

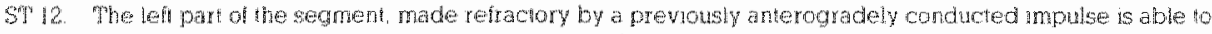

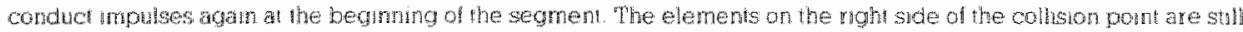
completely refractory

(13)

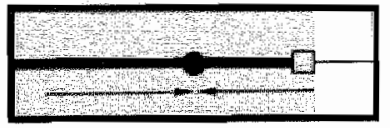

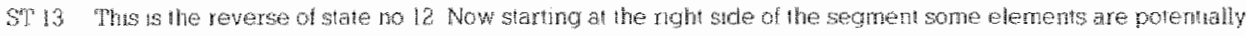
exclable.

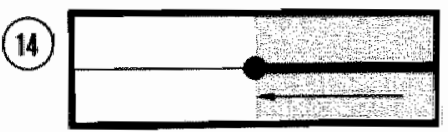

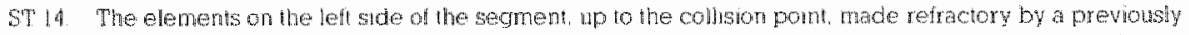

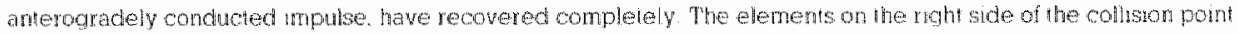
are still refractory.

(15)

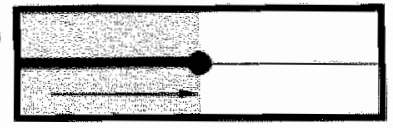

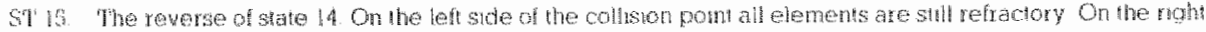
she however all elemerts are agrin exchable

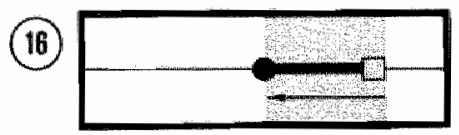

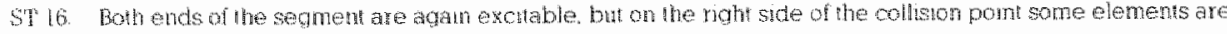
sillitrelacion 


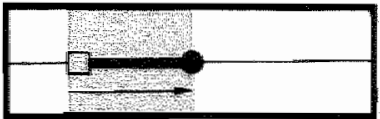

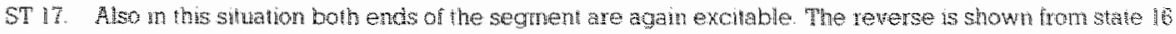

(18)

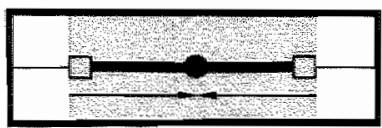

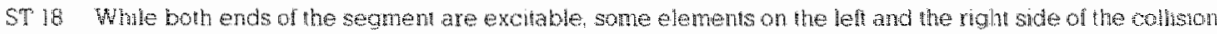
pont. are sit! rebactory.

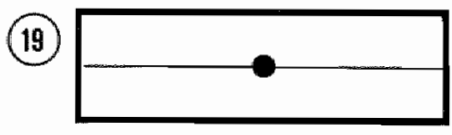

ST 19. This situation represents the ulimate one before the segment can be constered iolaly eledtickily excotable agan. By definum it will last for only one simulation cycle.

\section{(20)}

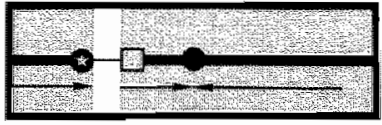

ST 20. Anterogradely an impulse is conducted in the difection of the collision pont. Some elements on the rith side of this irrupulse up to the collision point are still refictory. All elemerts on the right side of the collisicn pomt are sill relractory, caused by a previously retrogradely conducted inpulse.
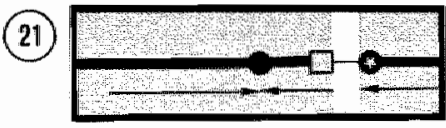

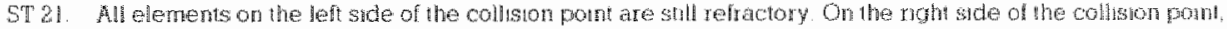

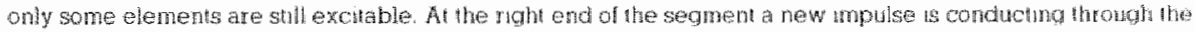
segment th retroguade direction
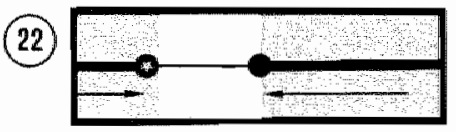

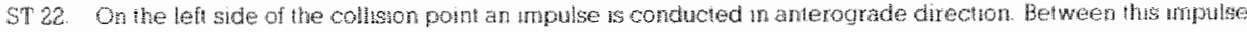
and the colluson pont al elements are exchable On the right side of the collsion pon all elements ate suth veractory. 


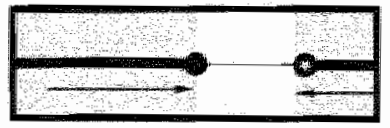

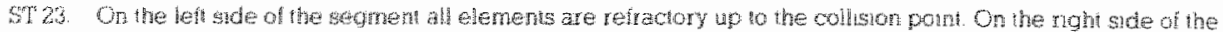

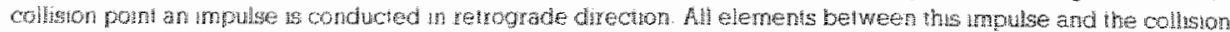
pont are achables.

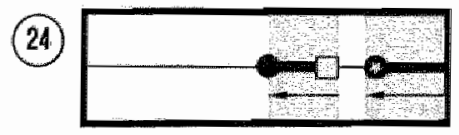

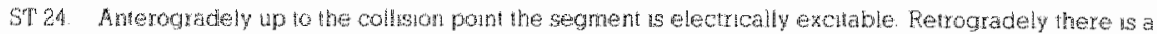
refratory hat in

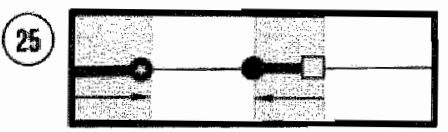

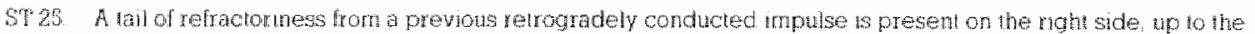

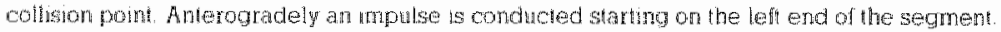

26)

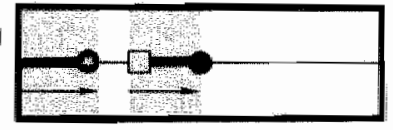

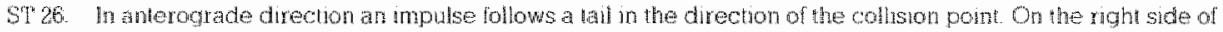
the collian poirt all elements are electrally exchable.
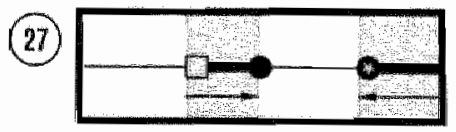

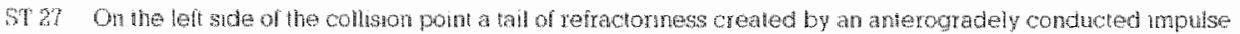

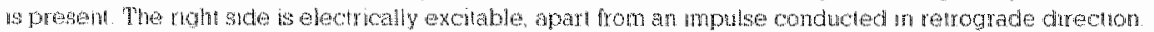

20

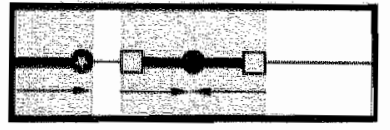

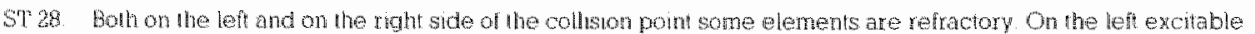
end an unpulse dis conduched in the anterograde direction. 


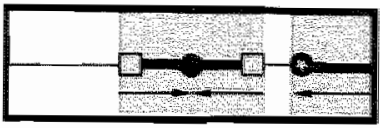

ST 29 . Thy is the reverse of stumion 28.

(30)

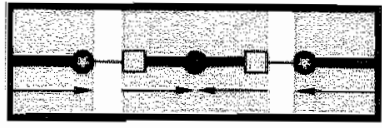

ST 30. In this situarion, as the who previous ones, a collaton point is present with a refractory tat at both sides fort both excitible ends an impulse is conduced in the drecton of the collision poin. These impulses ara Iollowed by a refractory tait.

\section{1}

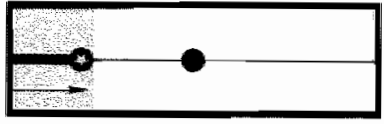

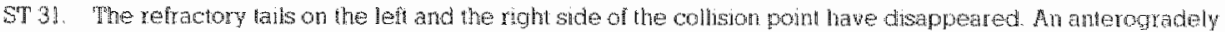
conducted new impulse followed by a retactory tail has enered the laft side of the secment.
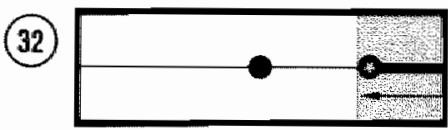

ST 32. The reverse of situation 31 .

33

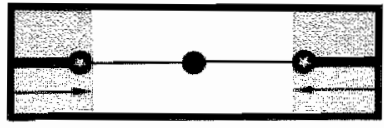

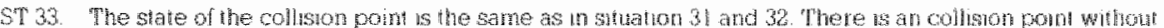

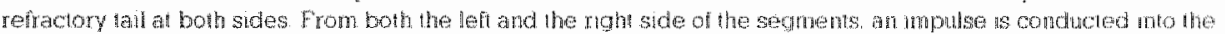
direction of the collsion pomen.

34

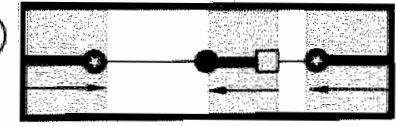

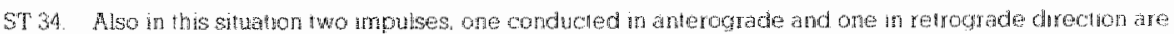

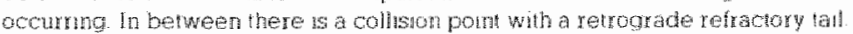

(35)

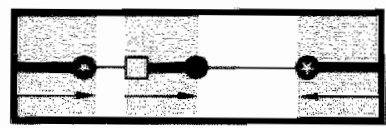

ST 35 . The snuation is the reverse of siuation 34 


\subsection{Order of handling.}

Possibilities

First we will discus the handling of impulses, which have been introduced into a segment in an earlier simulation cycle, the handling of the refractory tail and the collision point.

In paragraph 2.6 the introduction of external impulses will be discussed and lastly in paragraph 2.7 the influence of changes in electrophysiological parameters.

The 38 different states are all constructed using three different parameters, an impulse, (i) a tail ( $\mathrm{t}$ ) and a collision point. (c)

To select a uniform order of handling all combinations were considered and one selected (i t c).

Considering three different parameters $(i, t, c)$, six different permutations are possible:

$\begin{array}{llllll}\mathrm{i} & \mathrm{i} & \mathrm{t} & \mathrm{t} & \mathrm{c} & \mathrm{c} \\ \mathrm{t} & \mathrm{c} & \mathrm{i} & \mathrm{c} & \mathrm{i} & \mathrm{t} \\ \mathrm{c} & \mathrm{t} & \mathrm{c} & \mathrm{i} & \mathrm{t} & \mathrm{i}\end{array}$

The major decision to make is whether to handle in the final computer program an impulse before or after handling a tail.

If one selects the following sequence of handling: i $t \quad c$ (impulse, tail, collision point), it implies that looking in one direction, the minimum distance between the impulse and the end of the tail is greater than the distance over which an impulse can be conducted in one simulation cycle. Otherwise the impulse, being conducted first, will hit the tail running in front of it, which has not yet been handled.

When we select the sequence $t$ i $c$ : (tail-impulse) this mimimum distance is not required because the new position of the tail is determined first.

This minimum distance, which is chosen during the first order of handling, limits the number of possible new states, in this simulation program. An impulse which follows a tail cannot jump over that tail, or over a collision point in the same cycle. For example figure 2.4. ] shows a state of a segment and the possible states that can be reached during one simulation cycle. 


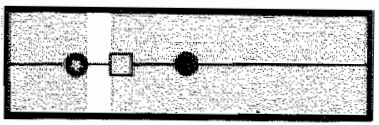

IMPULSE FIRST

(22)

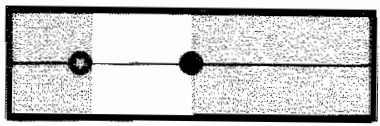

(25)

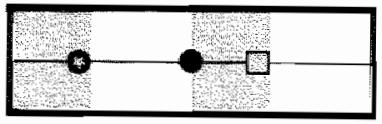

(28)

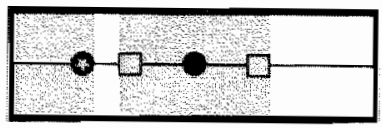

TAIL FIRST

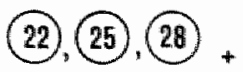

(11)

13

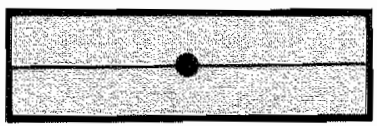

FIGURE 2.4.1.

Legend to figure 2.4. I This figure shows the states that cal be reached in one smmavion cycle starting from sate 20 On the left side all states that can be reached handing the impulse frist, are shown.

On the right side all possible states using the order - Tail-impulse-are indicaled Apart from the four states which are common to both cases $20,22,25,28$ there are two extra states possible: 11 and 13 .

In these wo situations an impulse conducis vver the collision point in the same simulation cycle as the lat preceding this impulse.

This increase in possibilities will uncrease the complexity and simuation time of the model.

The order of handling impulse-collision point has the consequence that the impulse first hits the collision point and then the model checks whether the collision point can be removed. This only makes a difference if an impulse hits a collision point with no tail at the opposite side. In the latter situation this will be removed in the sarne cycle.

For the order of handling tail-collision point the order obviously makes no difference.

The differences between these fwo options is marginal in normal cases. The maximum error in timing is one simulation cycle, which in most simulation studies equals $1 \mathrm{~ms}$.

Following the above considerations the first option was selected, first to handle the impulse, then the tail and finally the collision point.

By defining strictly the order of handling a reproducible and predictable handling of a segment can be performed.

\section{Order of handling selected:}

if any: Anterograde Impulse

Retrograde Impulse

Anterograde Tail

Retrograde Tail

Collision Point 
List of abbreviations used:

AP Anterograde Impulse $\quad 1 \leqslant A P<100$

$\mathrm{RP}$ Retrograde Impulse $\quad 1<\mathrm{RP} \leqslant 100$

AL Anterograde Tail $\quad 1 \leqslant$ AL $<100$

RL Retrograde Tail $\quad 1<R L \leqslant 100$

$\mathrm{CP}$ Collision Point $\quad 1<\mathrm{CP}<100$

AV Anterograde conduction velocity

RV Retrograde conduction velocity

AD Anterogradely conducted distance (number of cells)

RD Retrogradely conducted distance (number of cells)

AT Anterogradely Refractory Timer. This indicates the time interval, during which element 1 will remain refractory after an anterogradely conducted impulse.

RT Retrogradely Refractory Timer. This indicates the time interval, during which element 100 will remain refractory after a retrogradely conducted impulse.

PD Proportional displacement. This variable is used to calculate the location of the collision point taking into account the actual positions of the two colliding impulses and their conduction velocities.

$P D=\frac{R P-A P}{A D+R D}$

ARP Anterograde Refractory Period. This parameter represents the anterograde refractory period of a segment. It can either be constant or rate dependent.

RRP Retrograde Refractory Period. Represents the retrograde refractory period.

2.5 Handling of a segment without changes in electrophysiological parameters or new impulses

In this paragraph the layout of the equations used to calculate the new state of a segment without introducing new impulses will be illustrated.

In all equations the subscript $n$ or $n+1$ represents the $(n)^{\text {th }}$ or $(n+1)^{\text {th }}$ simulation cycle respectively.

To illustrate this layout the handling of two different states will be discussed in detail. 
a) State 2(ST 2)

In state 2 an impulse is being conducted anterogradely through a segment. In this state an impulse is conducted anterogradely ( $A P>0$, there is no retrogradely conducting impulse $(\mathrm{RP}=0)$, there are no anterograde or retrograde tails, nor a collision point. $(A L=0, R L=0, C P=0$ )

The element excited first is still refractory. (AT>0) The retrograde refractory timer equals zero. $(\mathrm{RT}=0$.

$$
A P_{n}>0 R P_{n}=0 A L_{n}=0 R L_{n}=0 A T_{n}>0 R T_{n}=0 \mathrm{CP}_{n}=0
$$

First the position of the anterograde impulse after one cycle is determined.

$$
A P_{n+1}=A P_{n}+A D
$$

The new position of the impulse equals the old one plus the Anterograde Conduction Distance.

If the impulse reaches or passes the end of the segment (element 100) the variable representing the position of the impulse will be reset to zero $\left(A P_{m+1}=0\right)$ and the new state of the segment will be indicated. $\left(\mathrm{ST}_{n+1}=\mathrm{ST} 3\right.$ ).

If the impulse does not reach the end of the segment in this simulation cycle these values remain unchanged. $\left(A P_{n+1}=A P_{n+1}\right.$ and $\left.S T_{n+1}=S T 2\right)$.

Summarized in computer terms:

$$
\begin{aligned}
& \operatorname{IF}\left(\mathrm{AP}_{\mathrm{n}+1}\right.\geqslant 100) \\
& \text { THEN }:^{A P_{n+1}=0} \\
& \mathrm{ST}_{\mathrm{n}+1}=\mathrm{ST} 3 \text { ELSE }: \mathrm{AP}_{\mathrm{n}+1}=\mathrm{AP}_{\mathrm{n}+1} \\
& \mathrm{ST}_{\mathrm{n}+1}=\mathrm{ST} 2
\end{aligned}
$$

Finally the Anterograde Refractory Timer, indicating the lime interval element 1 will remain refractory, is decreased by one.

$$
\mathrm{AT}_{\mathrm{n}+1}=\mathrm{AT}_{\mathrm{n}}-1
$$

In the second example a more complicated state will be discussed.

\section{b) State 20 (ST 20)}

Again the description of the handling of this state starts with a description of the values of all parameters before the next simulation.

Anteragradely an impulse and a tail are present. $\left(A P_{n}>0 A L_{n}>0\right)$ The first element is still refractory. $\left(A \mathrm{~T}_{\mathrm{n}}>0\right)$ Retrogradely there is no impulse and no tail present. $\left(R P_{n}=0 R L_{n}=0\right)$. Element number 100 is still refractory. $\left(R T_{n}>0\right)$. There is a collision point. $\left(\mathrm{CP}_{\mathrm{n}}>0\right)$

$$
A P_{n}>0 R P_{n}=0 A L_{n}>0 R L_{n}=0 A T_{n}>0 R T_{n}>0 \mathrm{CP}_{n}>0
$$


After one simulation cycle there is still no retrograde impulse. $\left(\mathrm{RP}_{\mathrm{n}+1}=0\right)$. The position of the collision point remains constant. $\left(\mathrm{CP}_{n+1}>0\right)$. The new position of the anterogradely conducted impuls equals the old one plus the Anterograde Conducted Distance. $\left(A P_{n+1}=A P_{n}+A D\right)$.

The new position of the anterograde conducted tail equals the old position plus the Anterograde Conduction Distance. $\left(A L_{n+1}=A L_{n}+A D\right)$.

$$
\begin{aligned}
& A P_{n+1}=A P_{n}+A D \\
& A L_{n+1}=A L_{n}+A D
\end{aligned}
$$

At this moment the model should check, whether the end of the tail has reached the collision point. If yes this is indicated by resetting the variable describing the position of the anterograde tail $\left(A L_{n+1}=0\right)$ and by defining the state to be equal to ST 22. If the lail does not reach the collision point these values are not changed.

$$
\begin{aligned}
& \text { IF }\left(\mathbb{A}_{n+1} \geqslant C P_{n}\right) \\
& \text { THEN : } A L_{n+1}=0 \quad \text { ELSE : } A L_{n+1}=A L_{n+1} \\
& \mathrm{ST}_{\mathrm{n}+1}=\mathrm{ST} 22 \quad \mathrm{ST}_{\mathrm{n}+1}=\mathrm{ST} 2 \mathrm{O}
\end{aligned}
$$

Thereafter both the Anterograde and the Retrograde Refractory "Timers are decreased by one.

$$
\begin{aligned}
& A T_{n+1}=A T_{n}-1 \\
& \mathrm{RT}_{\mathrm{n}+1}=\mathrm{RT}_{\mathrm{n}}-1
\end{aligned}
$$

After this decrement it is possible that element 100 is no longer refractory. In that case, if $R T_{n+1}=0$, the retrograde tail is given the value 100. Depending on the state of the segment two different states are possible. If the previous state represented ST 22 , the new state will be ST 25 . Otherwise the state will be ST 28. If this element is still refractory following this part of the simulation cycle both the values indicating the position of the retrograde tail and the state of the segment remain unchanged.

$$
\begin{aligned}
& \text { IF }\left(\mathrm{RT}_{\mathrm{n}+\mathrm{l}}=0\right) \\
& \text { THEN : } \mathrm{RL}_{\mathrm{n}+1}=100 \quad \text { ELSE : } \mathrm{RL}_{\mathrm{n}+1}=0 \\
& \text { IF }\left(\mathrm{ST}_{\mathrm{n}+1}=\mathrm{ST} 22\right) \\
& \text { THEN }^{\text {ST }}{ }_{n+1}=25 \quad \text { ELSE }: \mathrm{ST}_{\mathrm{n}+1}=\mathrm{ST} 28
\end{aligned}
$$

In chapter 6 the handling of all 35 states has been listed.

\section{The introduction of a new impulse.}

The introduction of an impulse into a segment forms the second step in every simulation cycle.

In the first step impulses which have been introduced into a segment during a previous simulation cycle have been handled together with possible tails and 
collision points. In the second step the model tests, whether at any of the junction points impulses are considered to be conducted into those segments which are connected to that specific junction point.

This impulse can either be an impulse conducted through an adjacent segment or a new impulse from an internal or extemal impulse source.

Impulses can only be introduced into a segment from the junction points and not somewhere in a segment.

Because it is possible that during one simulation cycle at both ends an impulse waiting to be conducted into a segment is present, the following must be noted the state of the segment changes as the result of an anterogradely or retrogradely introduced impulse. Therefore handling the second retrograde impulse recuires the new state after handling the first impulse, and not the state of the segment as it was just before the handling of the first impulse.

Before an impulse can enter a segment the following condition must be fulfilled

"The conditions are given for an anterogradely conducted impulse. For a retrograde impulse the values can be derived easily.

The impulse can only penetrate a segment if at the beginning of that segment a number of elements equalling the Anterograde Conduction Distance (AD) does not contain a refractory tail conducting in the same direction. The presence of a collision point in this area, or an impulse in the opposite direction forms no objection against the introduction of an impulse. This free space prevents the impulse from jumping over a preceding tail in the next simulation cycle. If this condition is fulfilled, an impulse is introduced to position one and a timer (the Anterograde Refractory Timer) starts to count down the refractory period of the anterograde junction.

If this condition is not fulfilled, the potential impulse will be ignored.

To define the condition of a segment in cycle $n+1$, based on the situation in cycle $\mathrm{I}_{1}$ a fixed procedure of handling is followed.

In the following part the introduction of an inpulse in a segment depending on the state of that segment will be described in detail. Using three examples all different possibilities are shown.

Chapter 7 gives a complete description of the procedures used to handle new impulses for each of the 35 possible states.

In the formula used ARP and RRP represent the anterograde and retrograde refractory period respectively. They have been defined separately for each segment and can either be constant or rate dependent.

In the following examples $\mathrm{n}$ indicates the situation before, and $\mathrm{n}+\mathrm{I}$ the situation after the introduction of an impulse into a segment.

Example 1. State 1.

As described in chapter 7 the introduction of a new impulse into a segment starts with a description of the present state.

In state 1 . no elements are activated in the segment so all walues are by definition equal to zero. 
ST 1. $A P_{\mathrm{n}}=0 R P_{\mathrm{n}}=0 \mathrm{AL}_{\mathrm{n}}=0 \mathrm{RL_{ \textrm {n } }}=0 \mathrm{AT} \mathrm{T}_{\mathrm{n}}=0 \mathrm{RT} \mathrm{T}_{\mathrm{n}}=0 \mathrm{CP} \mathrm{P}_{\mathrm{n}}=0$

All elements are excitable therefore an anterograde impulse can always be introduced into the segment.

The impulse will be introduced to position $\|\left(A_{\mathrm{P}}+1=1\right)$ and will set the Anterograde Refractory Timer equal to the Anterograde Refractory Period. $\left(A T_{n+1}=A R P\right)$. There is still no anterograde tail. $\left(A L_{n+1}=0\right)$. In retrograde direction all values remain equal to zero $\left(R P_{n+1}=0, R L_{n+1}=0, R T_{n+1}=0\right)$. There is no collision point. $\left(\mathrm{CP}_{\mathrm{n}+1}=0\right)$. After the introduction of an anterograde impulse the state of the segment changes into ST 2

$$
\text { ANT } \begin{array}{ll}
\mathrm{AP}_{\mathrm{n}+1}=1 \mathrm{RP} \\
\mathrm{CP} P_{n+1}=0 \mathrm{ST}_{\mathrm{n}+1}=\mathrm{ST} 2
\end{array}
$$

Also in retrograde direction an impulse can always penetrate into such a segment. Now the impulse will be introduced to position $100\left(\mathrm{RP}_{\mathrm{n}+1}=100\right)$ and the Retrograde Refractoy Timer will be set equal to the retrograde Refractory Period. $\left(\mathrm{RT}_{n+1}=\mathrm{RRP}\right)$. There is no retrograde tail. $\left(\mathrm{R} \mathrm{L}_{n+1}=0\right)$. All anterograde values remain zero. $\left(A P_{n+1}=0, A L_{n+1}=0, A P_{n+1}=0\right)$ There is no collision point. $\left(C P_{n+1}=0\right)$. The new state of the segment is $\mathrm{ST} G$.

$$
\text { RET } \begin{aligned}
& A P_{n+1}=0 R P_{n+1}=100 A L_{n+1}=0 R L_{n+1}=0 A T_{n+1}=0 R T_{n+1}=R R P \\
& C P_{n+1}=0 S T_{n+1}=S T 6
\end{aligned}
$$

In the second example the introduction of an impulse in a segment with one refractory end will be discussed.

State 2

The description starts again with a description of the present state.

ST 2. $A P_{n}>0 R P_{n}=0 A L_{n}=0 R L_{n}=0 A T_{n}>0 R T_{n}=0 \mathrm{CP}_{n}=0$

$A^{T} T_{n}>0$ indicates that the first element of the segment is still refractory. New impulses can not penetrate into the segment in anterograde direction and all values remain unchanged

ANT $A P_{n+1}>0 \mathrm{RP}_{\mathrm{n}+1}=0 A \mathrm{~L}_{\mathrm{n}+1}=0 \mathrm{RL}_{\mathrm{n}+1}=0 \mathrm{AT} \mathrm{T}_{\mathrm{n}+1}>0 \mathrm{RT}_{\mathrm{n}+1}=0 \mathrm{CP} \mathrm{P}_{\mathrm{n}+1}=0$

The introduction of an impulse from the retrograde side of the segment is in this state always possible. The first element $(100)$ is not refractory and there is also no tall which is conducted in retrograde direction.

Therefore after the introduction of an impulse at element 100 the properties of the segment will be as follows:

$$
\text { RET } \begin{aligned}
& A P_{n+1}>0 R P_{n+1}=100 A L_{n+1}=0 R L_{n+1}=0 A T_{n+1}>0 R T_{n+1}=R R P \\
& C P_{n+1}=0 \mathrm{ST}_{n+1}=S T 10
\end{aligned}
$$


Finally in the last example the third and most complicated case will be demonstrated.

State 4.

In this state in anterograde direction a refractory tail is being conducted. Behind this tail at the left side a sector of the segment is again excitable. $\left(A P_{n}=0, A L_{n}>0\right.$, $A T_{M}=0$ ).

Retrogradely there is no impulse nor tail present. There is no collision point. $\left(R P_{n}=0, R L_{n}=0, R T_{n}=0, C P_{n}=0\right)$

ST 4. $A P_{n}=0 R P_{n}=0 A L_{n}>0 R L_{n}=0 A T_{n}=0 R T_{n}=0 \mathrm{CP}_{n}=0$

Independent of the fact whether an impulse can enter the segment in anterograde direction or not, the values indicating the position of the anterograde tail together with those representing the retrograde values and the collision point remain unchanged.

ANT $R P_{n+1}=0 A L_{n+1}>0 \mathrm{RL}_{\mathrm{n}+1}=0 \mathrm{RT}_{\mathrm{n}+1}=0 \mathrm{CP}_{\mathrm{n}+1}=0$

In this situation one has to check whether an impulse, introduced at element $l_{\text {, }}$ would hit the preceding tail. If so, the impulse will be ignored. If not, the impulse can enter the segment $\left(\mathrm{AP}_{\mathrm{n}+1}=1, A \mathrm{~T}_{\mathrm{n}+1}=\mathrm{ARP}\right)$ and the new state will represent ST 5 .

IF $\left(A I_{n+1}>(1+A D)\right)$
THEN : $\operatorname{AP}_{\mathrm{n}+1}=1$
$A T_{n+1}=A R P$
ELSE : $A P_{n+1}=0$
$\mathrm{ST}_{\mathrm{n}+1}=\mathrm{ST} 5$
$A T_{n+1}=0$
$\mathrm{ST}_{\mathrm{n}+1}=\mathrm{ST} 4$

In retrograde direction impulse introduction is impossible since element 100 is still refractory. $\left(A L_{n}>0, C P_{n}=0\right)$.

All values remain unchanged.

RET $\quad A P_{n+1}=0 \mathrm{RP}_{\mathrm{n}+1}=0 \mathrm{AL}_{\mathrm{n}+1}>0 \mathrm{RL}_{\mathrm{n}+1}=0 \mathrm{AT} \mathrm{T}_{\mathrm{n}+1}=0 \mathrm{RT}_{\mathrm{n}+1}=0 \mathrm{CP_{n+1 }}=0$

2.7 Consequences of short refractory periods and non constant conduction velocity.

So far two major limitations are present in the model.

1: As a result of the definitions choosen, leading to the 35 states the conduction time through a segment is shorter than the refractory period of the segment in the same direction.

2: The conduction velocity of an impulse or tail travelling through a segment is constant as long as the impulse or its tail are present in any part of the segment. 


\section{Limitation 1. A short refractory period}

A conduction time through a segment, shorter than the refractory period of that segment, makes it impossible that two impulses will be conducted in one segment in the same direction.

Eliminating this principle will increase the number of possibilities from 35 to almost infinite making acceptable processing impossible.

If the user is confronted with a situation in which the conduction time is only slightly longer than the refractory period the problem can be solved in some situations by lining up multiple segments, each segment having a conduction time equal to the total conduction time divided by the number of subsequent subsegments. All these subsegments will have the original refractory period.

This division of the original segment into subsegments is only possible if the conduction time through the segment is not a function of the rate at which the impulses enter the segment.

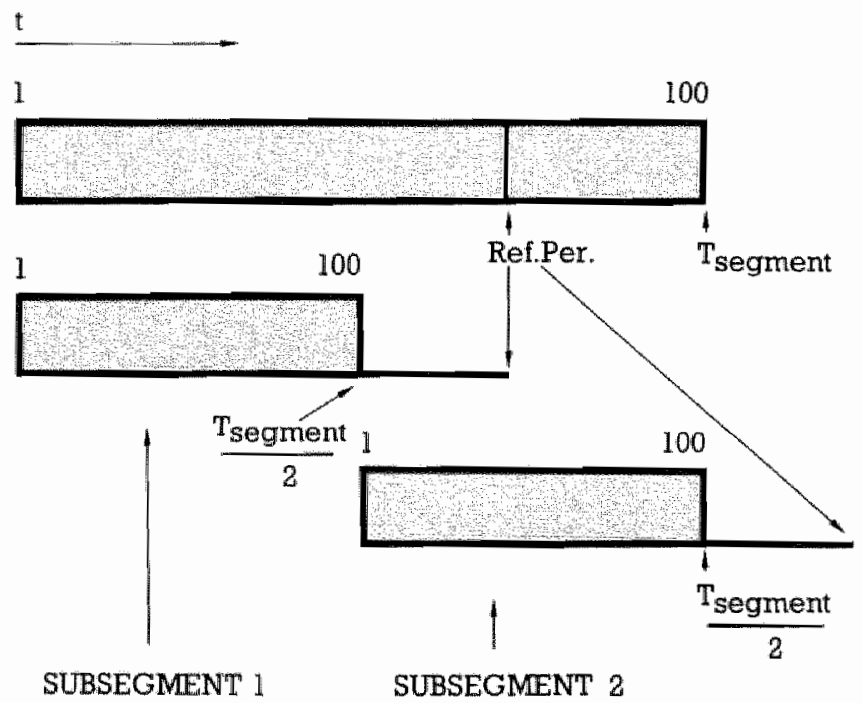

FIGURE 2.7.1.

thegend to frowe ?.7.1.

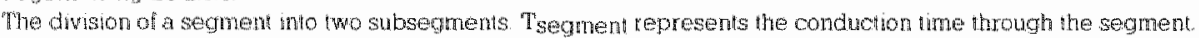
This solthon cannot be used if the conduction the through the segment is rate dependent for example when

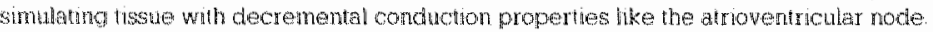


Fig2.7.2. shows the function curve of a segment where the conduction time of the segment is a function of the input rate.

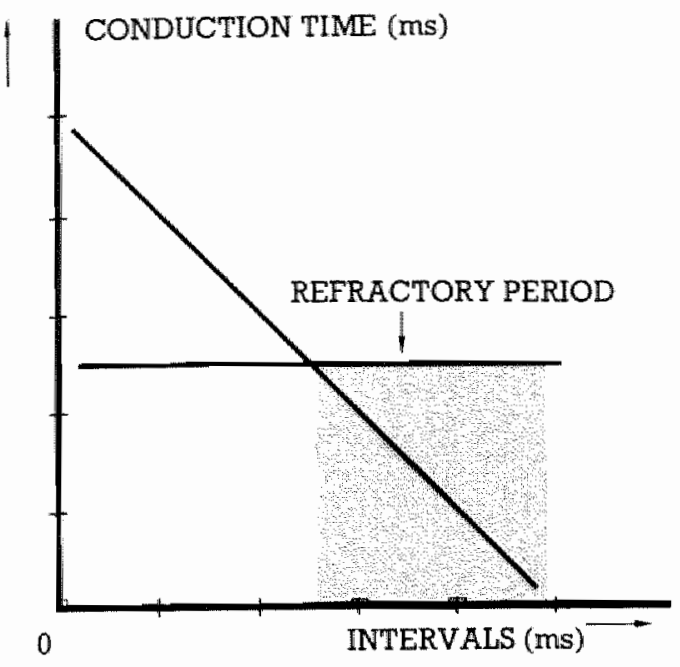

FIGURE 2.7.2.

Legend to higr 272

The shaded area tepresents that part of the function curve that can be used during the smulaton shudy. In his part the conduction time is smaller than the refractory period. (Mostly the refractory period will atso be rate dependant)

Before an impulse can enter a segment with rate dependent properties, the actual electrophysiological parameters have to be determined. If conduction time is shorter than the refractory period, the segment can be handled as a normal segment with the appropriate conduction time and velocity The refractory period of the segment can also be defined as rate dependent. In such a situation the segment can be handled as a normal segment if the conduction time at a certain rate is shorter than the refractory period of the segment at that rate.

If, corrected for the actual rate, the conduction time is not shorter than the refractory period the problem cannot be solved by dividing the segment into subsequent subsegments.

Handing the segment as a normal segment, by dividing the conduction time of the original segment by the number of subsegments (n), the following sub-function curves will apply. 


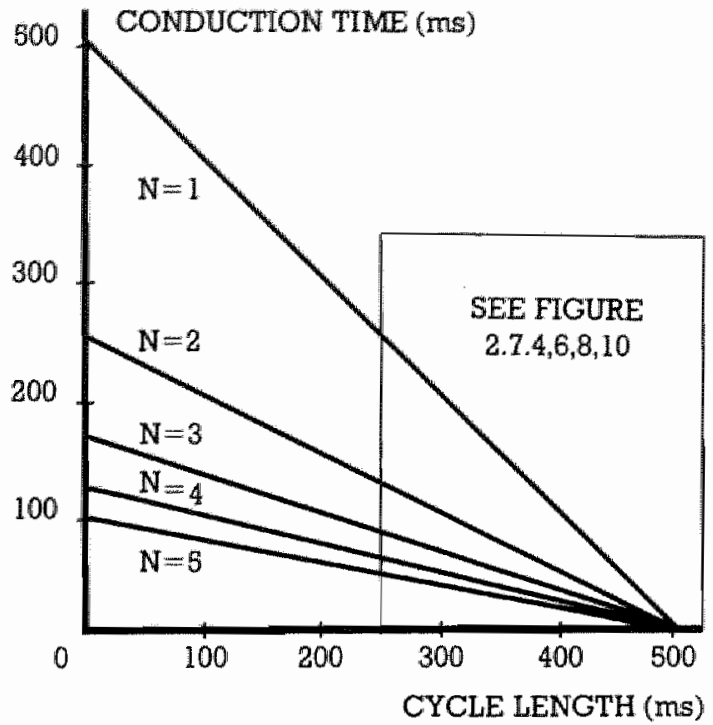

FIGURE 2.7.3.

Legend to higure : 73

This figure shows a number of rate dependent funtion curver "The top one $(\mathrm{n}=1)$ is defined by the equath

Conduction time $=900$. cycle length

The other curves are deriwed trom this curve by dividing the conduction the at any rate by $2,3,4$ or 5

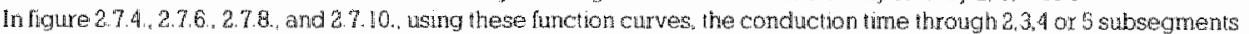
is indicated

During a constant rhythm the division of a rate dependent segment into subsegments does not change the performance of the segment. In the following part at a basic rate of $400 \mathrm{~ms}$ the response to a premature impulse at $300 \mathrm{~ms}$ is stuclied.

Using these values, we will show, that the behaviour of a premature impulse depends also on the number of subsegments into which a segment has been divided.

On dividing the segment into n subsegments the time sequence of conduction through these subsegments is as follows.

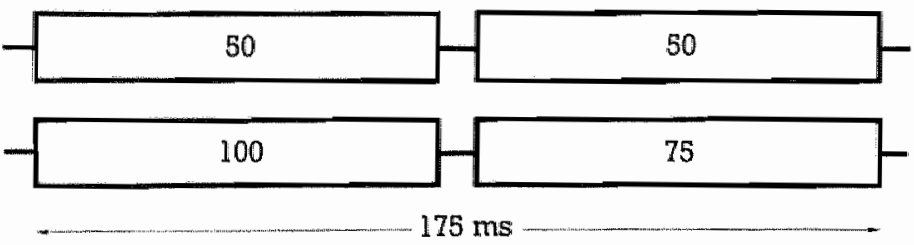

FIGURE 2.7.4.

Legend lo ligue 274

The secmeni has been diwded rnto wo subsegments. The top segment indicates the conducton time dunng a regular rate of 400 ms. "The bot:om one shows the response of the subsegments to a premature unpulse after an interval on 300 ins. 


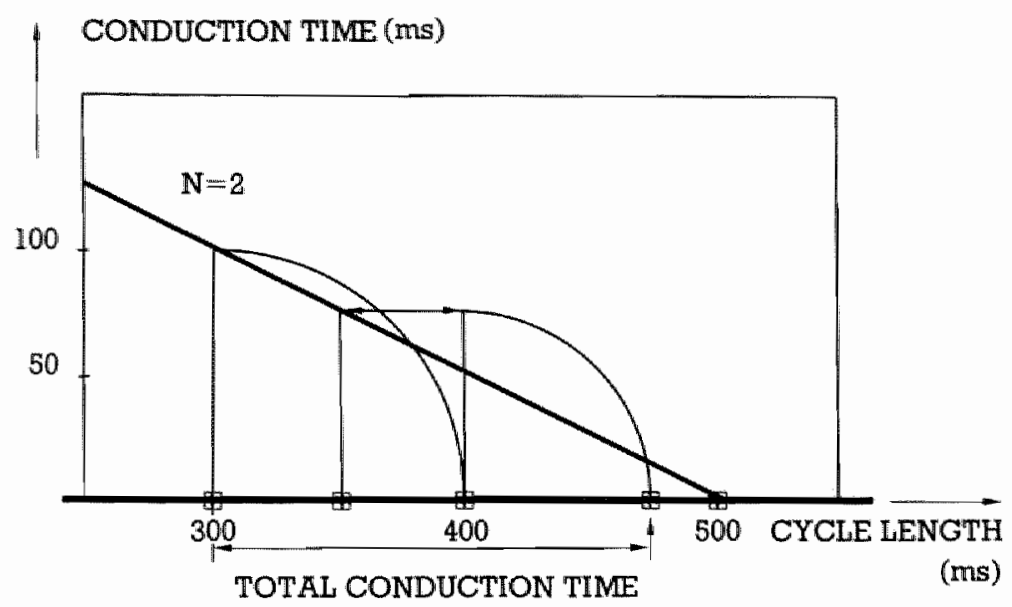

FIGURE 2.7.5.

Legerd to figure 2.5 .5 .

The first subsegment is confronted with a premature impulse with a couphing interval of 300 ms this sesuls in at conduction time interval of $200 \mathrm{~m}=100 \mathrm{~ms}$. The wherval is $50 \mathrm{~ms}$ longer that the conduction fine during the regular rate of 400 ms. So the prematurity of the premature inpulse at the second segment is no longer 100 mas, but $100 \mathrm{nns}$ milus the so mas extra delay in the first subsegment. (finterval $350 \mathrm{~ms}$ for second segment) fhis gives a lohal conduction. time of $175 \mathrm{~ms}$.

On dividing the segment into three subsegments the following situation appears.

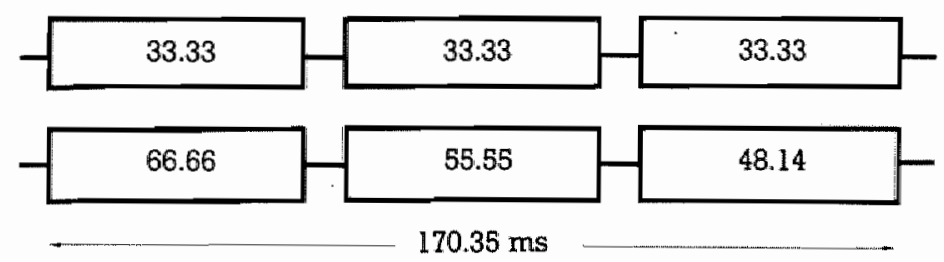

FIGURE 2.7.6.

Hegend to frume 2.7.6.

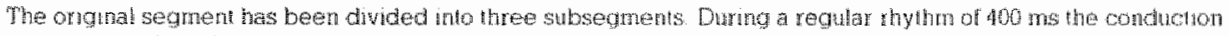
me through the subsegmenis is $3333 \mathrm{~ms}$

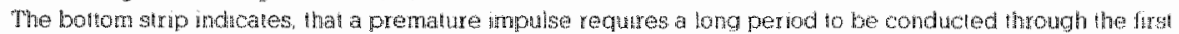

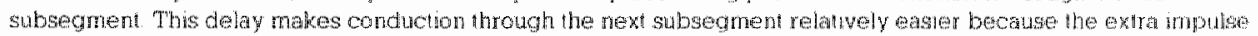
as arrving less prematurely al ths and all the foltowng subsegments. 


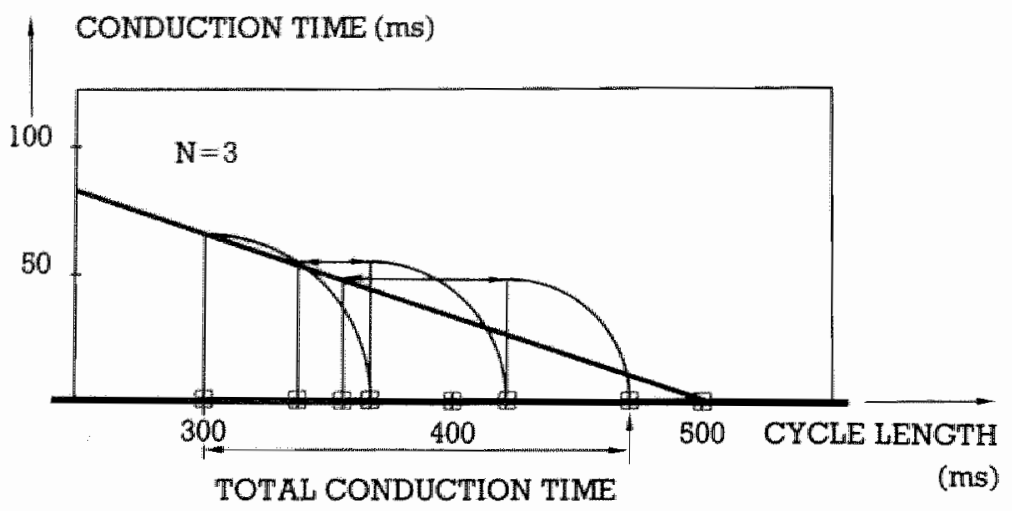

FIGURE 2.7.7.

Legend to floure 237

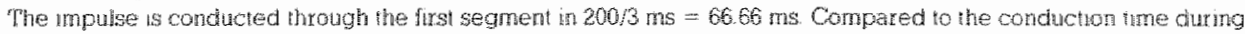

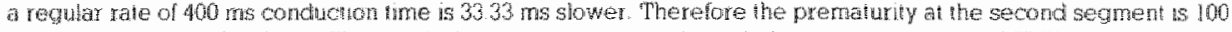

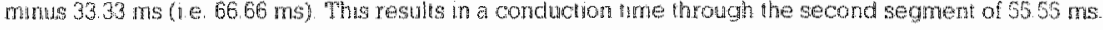

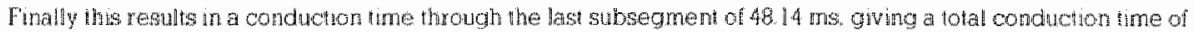
$170.3 \mathrm{sin} \mathrm{me}$

After the division in four subsegments the situation is as follows.

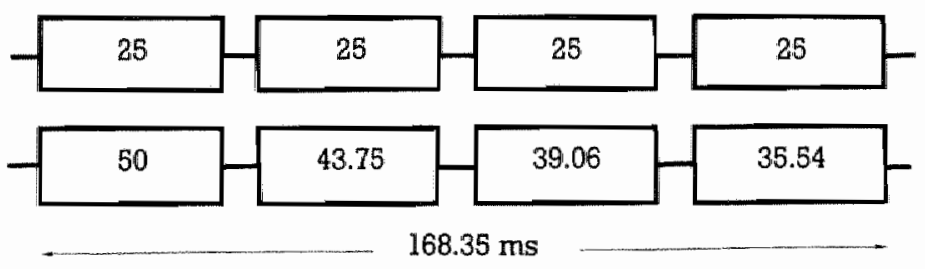

FIGURE 2.7.8.

Lemend to horte 2.7 .8

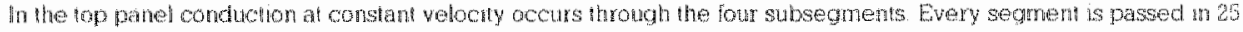

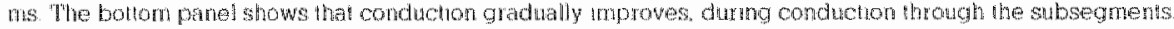




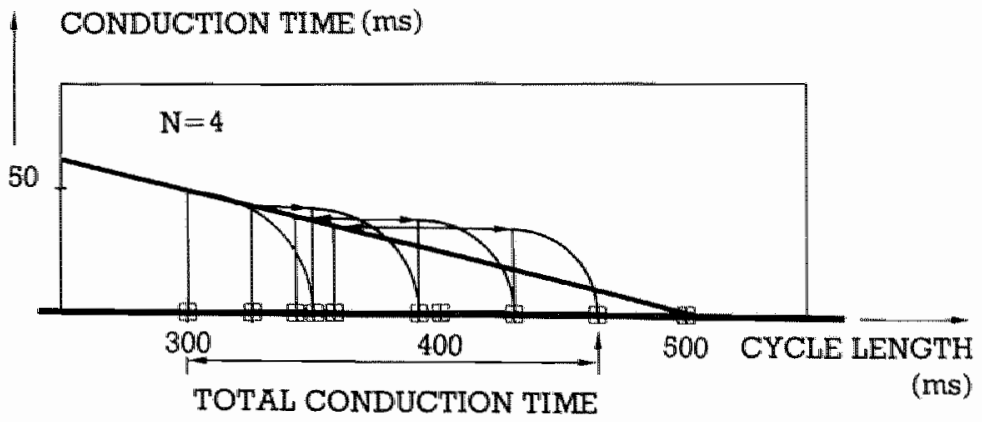

FIGURE 2.7.9.

Legend to figue 27.7

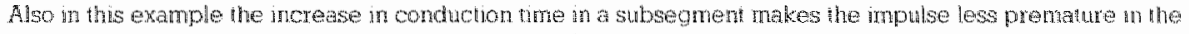

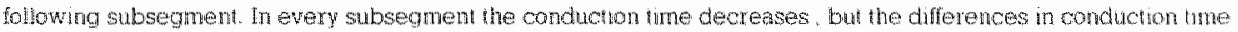
between two subsegments decrease also.

Division in five parts gives this result.

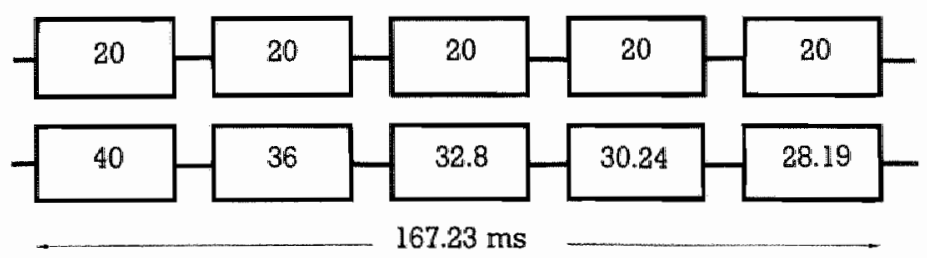

FIGURE 2.7.10.

Legend to figure 2.7 .10

"The onducton tme per subsegment in the top panel numbers 20 ms. In the botom panel the same shechansm of reduction in conduction time is show r. 


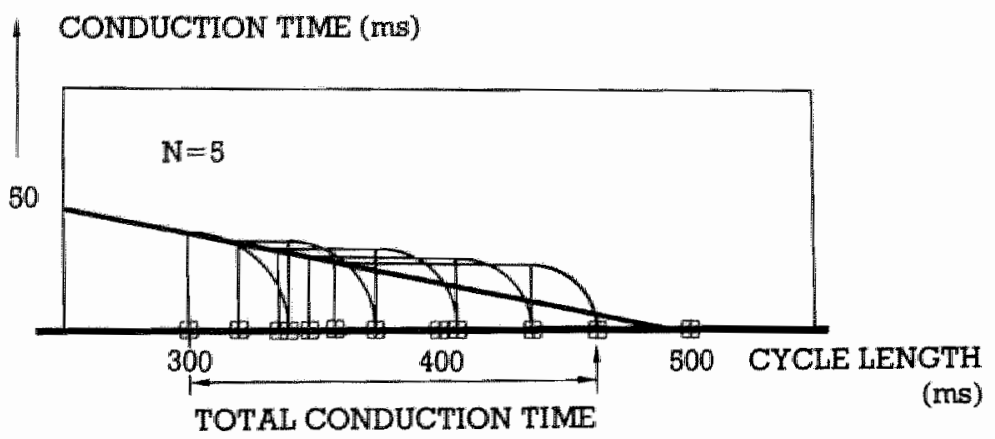

FIGURE 2.7.11.

Legend to figure 2.7. 1. As in the wrewous examples, this diagram mocates the decrasing shorteng of the concluchun time throwgh a row of subsegments. The tolat conduction the ihrough a segment divded in Iiwe

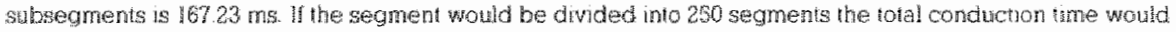
derresse $1016328 \mathrm{~ms}$

\section{Limitation 2. Non constant conduction velocity}

Fig 2.7.12. shows all situations in which an increase in conduction velocity will be in conflict with the limiting criterion no 2 , the consistency of the conduction velocity.

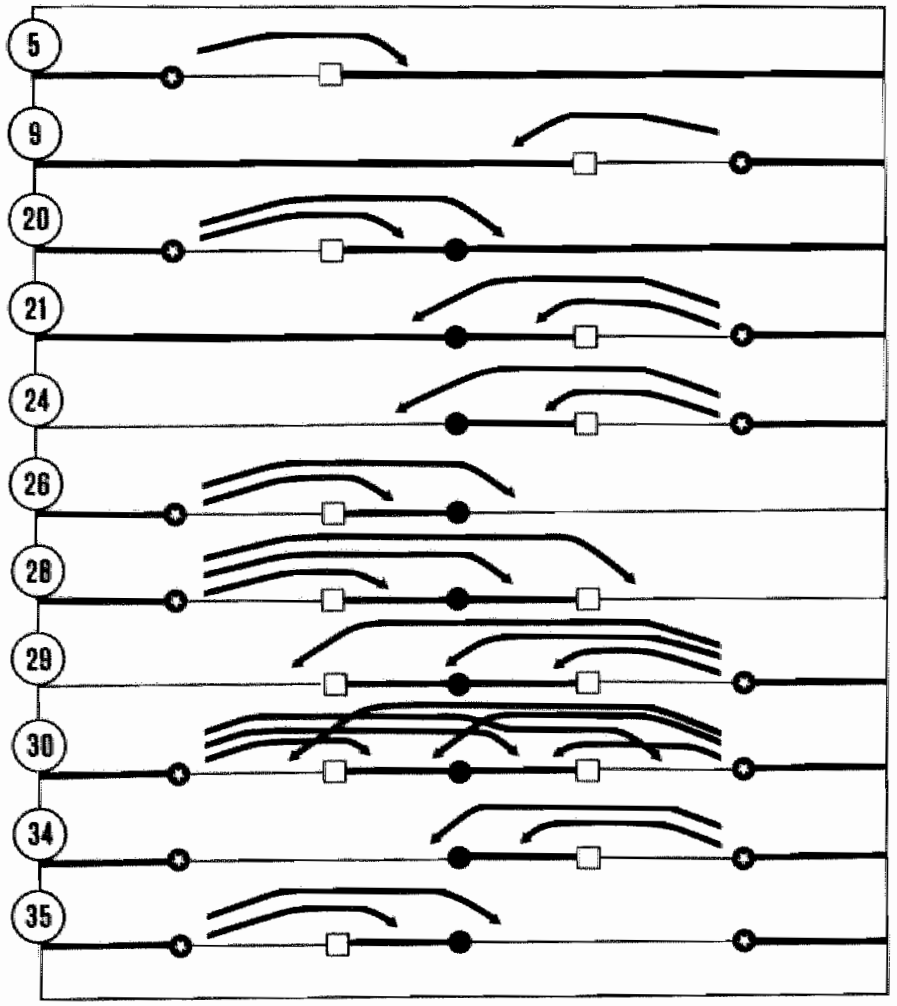

FIGURE 2.7.12.

Leqend to toure 2: 2.12

This figure showe the shuations which an increase of conduction velocty could cause mistakes In these cases it is posstble that an irpulse is conducted over the position of a preceding tail or ewen over a tain and a coltison point. These dlegal jumps are nolcated by anows. 
The fact that the impulse is handled before the tail makes it possible in these situations that the calculated position of the impulse will be more distal then the position of the tail or even the collision point.

If one of the situations listed here is present the following extra tests must be performed before a segment can be handled in the way previously described.

$$
\begin{aligned}
& \operatorname{IF}\left(A L_{n}-A P_{n}\right) \leqslant A D \text { then } A D=\left(A L_{n}-A P_{n}\right) * 0.99 \\
& I F\left(R P_{n}-R L_{n}\right) \leqslant R D \text { then } R D=\left(R P_{n}-R L_{n}\right) * 0.99
\end{aligned}
$$

(The value 0.99 has been selected arbitrarily. )

By adding this extra restriction it becomes impossible for the impulse to jump over the tail, (i.e. preventing a situation not listed in the 35 possible states. This test only needs to be performed if the $A V_{n-1}$ is not equal to the $A V_{n !}$ or $R V_{n-1}$ not equal to $\mathrm{RV}_{\mathrm{n}}$

By using this restriction in conduction velocity to keep the impulse behind the tail, both the impulse and the tail are conducted within a segment at a fixed minimal distance.

Using the model the frequency of occurence of this phenomenon is very low. During the simulation studies, described in chapter 3 , it never occured.

If an impulse enters in this way into the next segment three situations are possible,

1) The new segment has the same properties and this state will continue

2) The refractory period of the new segment is longer and the impulse will block

3) The refractory period of the new segment is shorter and the gap in between the impulse and the tail increases.

If after a change in conduction velocity, the velocity remains constant, the gap between the impulse and the tail will remain at least $101 \%$ of the minimally required distance.

This correction in conduction velocity will be indicated to the user by a statement in the output. 


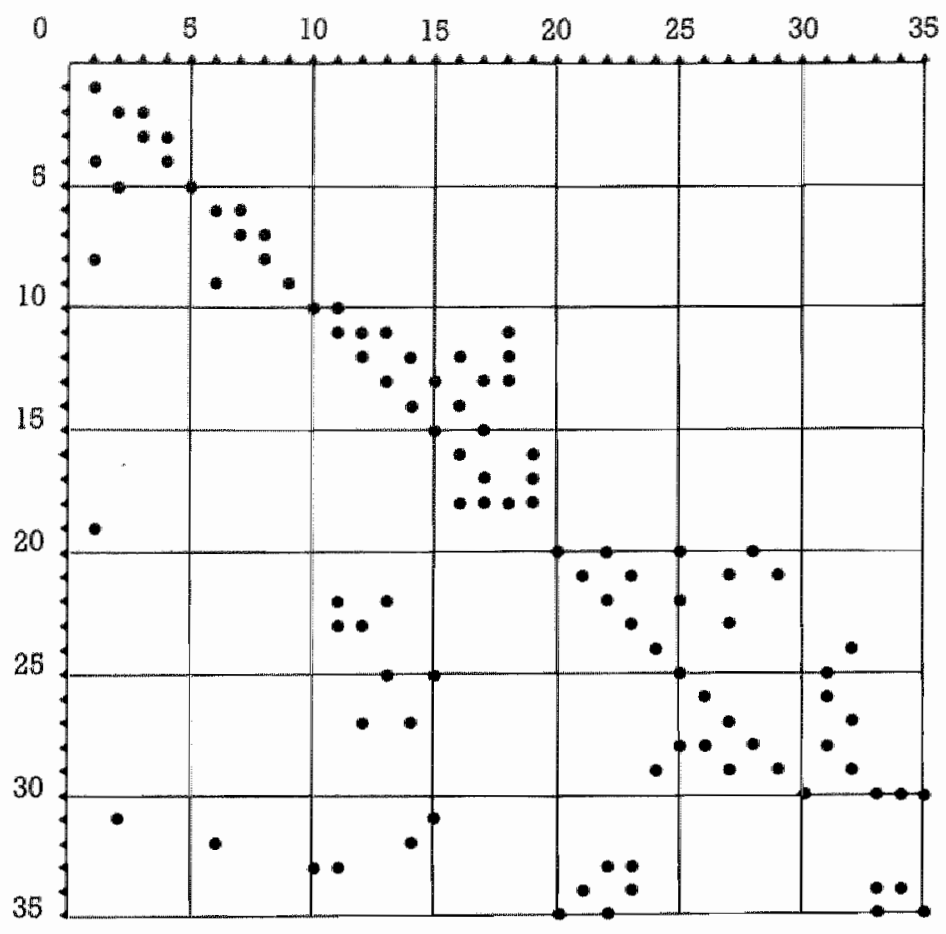

TABLE 2.7.1.

Table 27.1. represents the situation that can be reached in any cycle if no exir impulse is antered and the electrophysological properites remair constant

The columus represent each of the 35 possible states in the $\mathrm{n}^{\text {th }}$ cyule. Rows represent be prssible state in the $(\mathrm{n})+)^{\mathrm{th}}$ cycle.

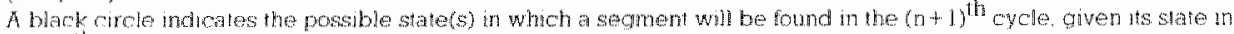
the ming oyose 


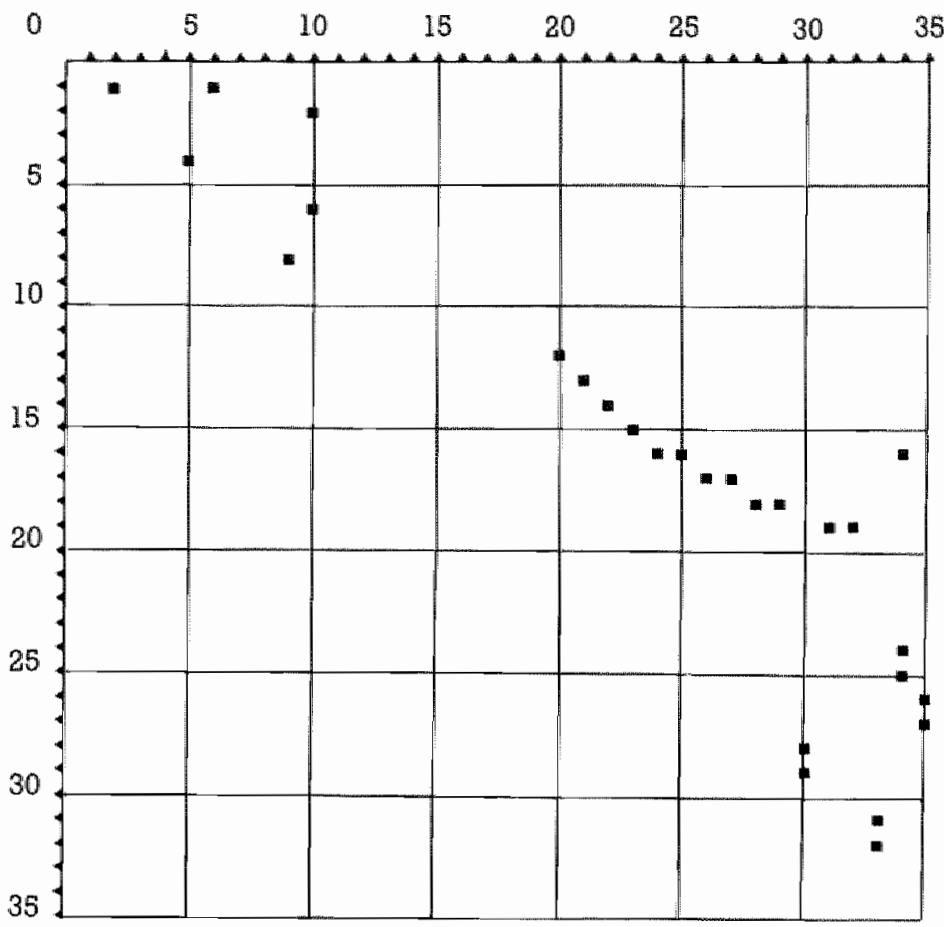

TABLE 2.T.2.

Table 2.7.2. represens the situation that can be reached in anv cycle an axtra mpulse has entered the segrient but the electrophysiologica! properties remain unchanged

Lke in table 2.7 . the colums represen each of the 35 possible states in the (n) cyole. Rows reprosent he possible state after the introduction of an mpulse.

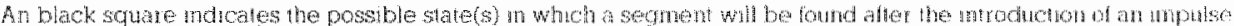

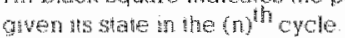




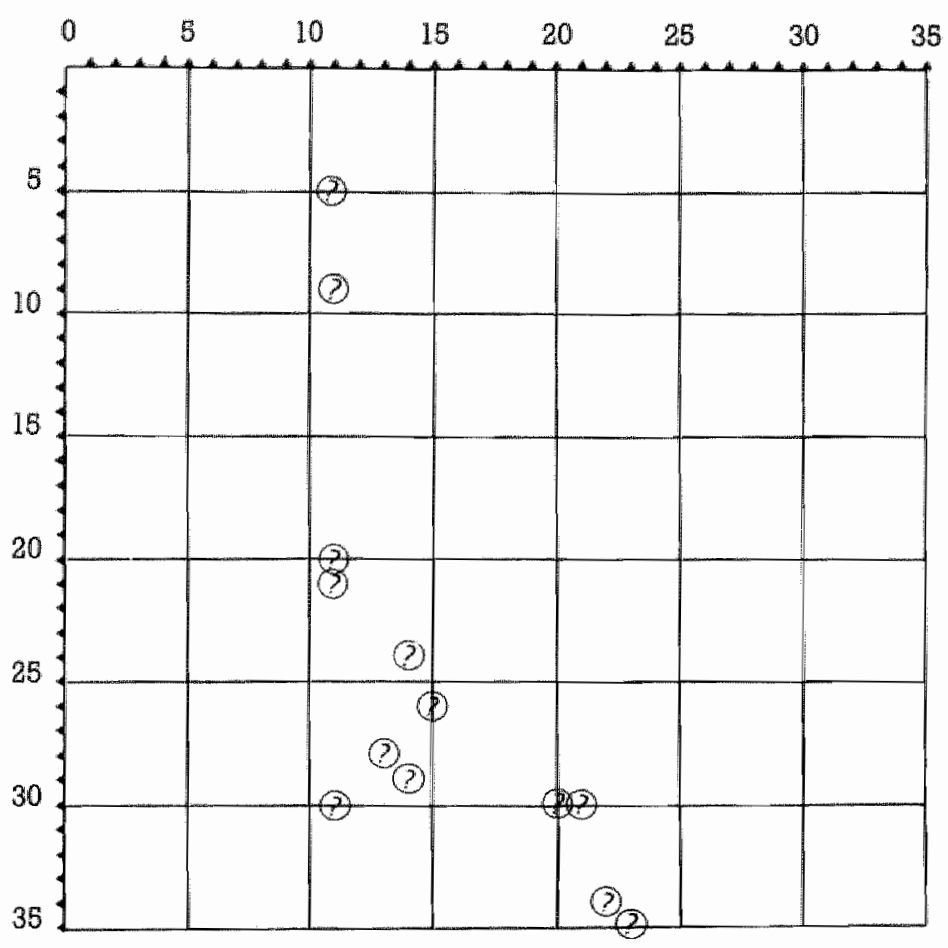

TABLE 2.7.3.

Table 2.73. represents the supplemental situation that can be reached in any cycle no natra impulse is entered and the electrophysiological prowerties are allowed uritimiled chanoses (see fugure 2.7. 12.)

Also in this table. the columns represent each of the 35 passuble states in the $y^{\text {th }}$ cycle. Fows represerut the state in the $(n+1)^{\text {th }}$ cycle that correspends most with the new state.

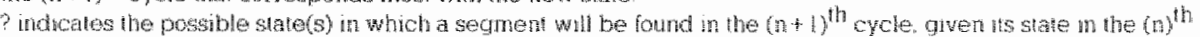
cycie. 


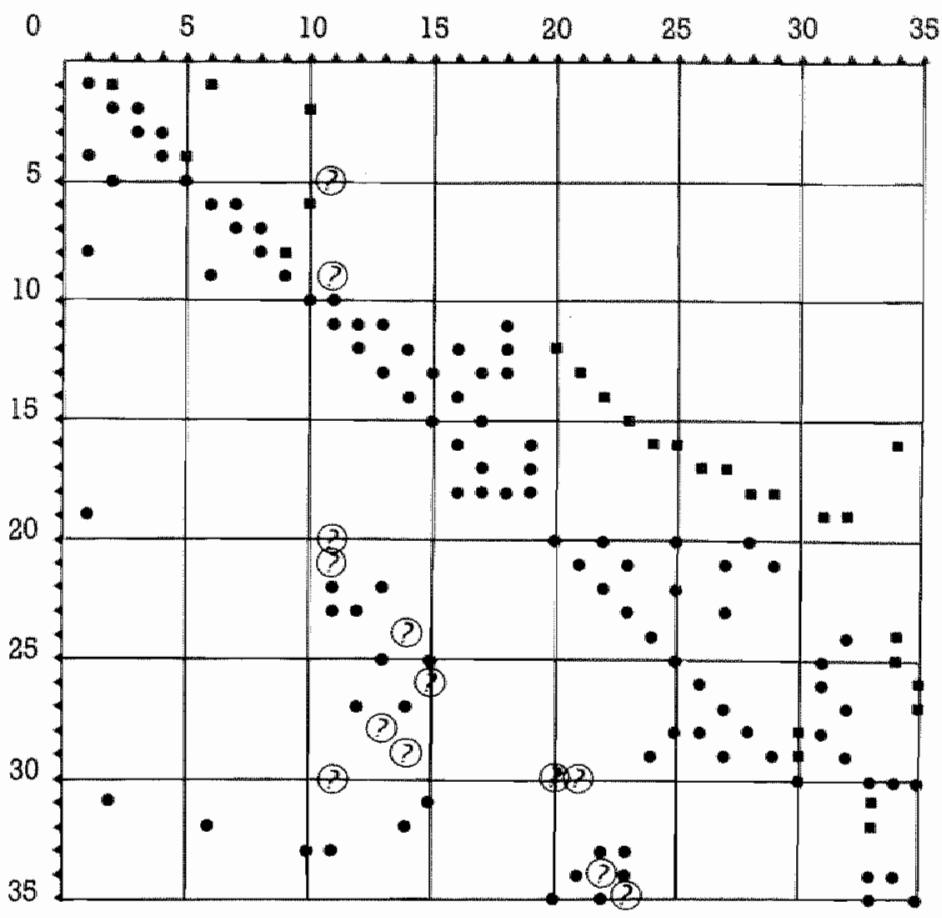

TABLE 2.7.4.

Table 2.74. represents a complation of all the the situations that can be reached in any cycle.

The coltmms represent each of the 35 possible states in the $(n)^{\text {th }}$ cycle. Fows represent the possible state in the $(n+1)^{\text {th }}$ cycle or ater the introduction of an inpulse.

Circles, Squares and ? have the same meanng as in previous tables. 


\section{Chapter 3}

Some simulation studies using the model

In this chapter we would like to show the results of some simulation studies performed using the previously described model. First a model of the normal cardiac conduction system of the heart will be designed. We will demonstrate how to define the network, and how to enter the electrophysiological properties of the segments, together with the extra stimuli given.

In the second paragraph a previously published simulation study, $(47)$ in which a single purpose mathematical model was used, will be described brielly. The simulation study has been repeated using our model and the results of both methods are compared. As will be shown there is a very good correlation between the original study and the findings using this model

Finally a more complicated study concerning termination and re-initiation of circus movement tachycardia, due to bundle branch reentry will be described. The last two examples are based on data collected during electrophysiological investigation. Both cases have been published previously. $(47-48,50)$. In

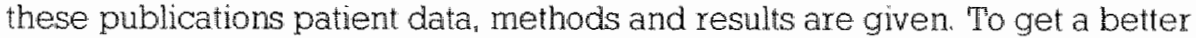
understanding of the mechanisms, responsible for these findings, sirnulation studies were performed.

\subsection{The normal conduction system}
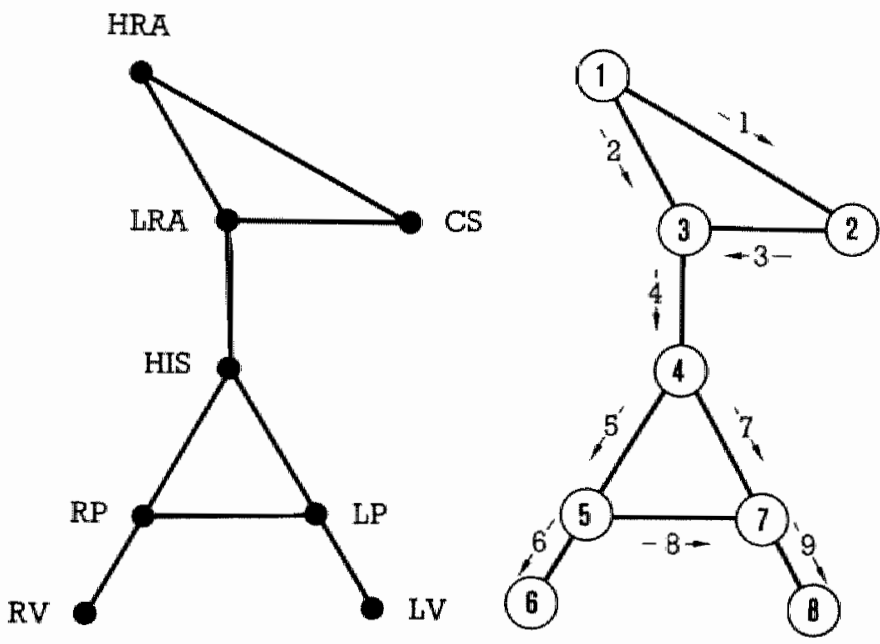

FICURE 3.1.1。

Legend to figure 3 . 1. 1.

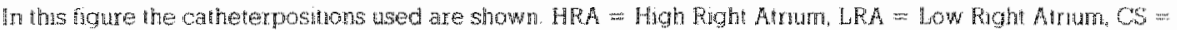

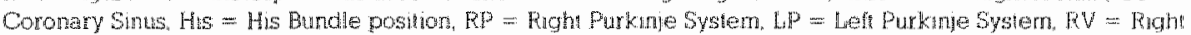
Ventricle, Ly = Left Wentricle

At he roh side all juction points and segments are number One drecton of conducton is defired bo be anterograde (ndicated by arrowsi) 
To simulate the behaviour of the cardiac conduction system the following network is assumed to represent a particular physiological situation in man

After numbering both the junction points and the segments, and defining an anterograde direction in every segment the model has been defined completely and can be entered into the computer.

To do this, for every junction point, a list of segments, able to conduct from that junction point, together with the direction, must be entered into the computer.

In our example the list has the following format:

$\begin{array}{ccc}\begin{array}{c}\text { Junction } \\ \text { Point }\end{array} & \begin{array}{c}\text { Segment Direction } \\ \text { Number }\end{array} \text { 1=Ant }=\text { Ret } \\ 1 & 1 & 1 \\ 1 & 2 & 1 \\ 2 & 1 & 2 \\ 2 & 3 & 1 \\ 3 & 2 & 2 \\ 3 & 3 & 2 \\ 3 & 4 & 1 \\ 4 & 4 & 2 \\ 4 & 5 & 1 \\ 4 & 7 & 1 \\ 5 & 5 & 2 \\ 5 & 6 & 1 \\ 5 & 8 & 1 \\ 6 & 6 & 2 \\ 7 & 7 & 2 \\ 7 & 8 & 2 \\ 7 & 9 & 1 \\ 8 & 9 & 2\end{array}$

If for instance between junction point 4 and junction point 5 conduction is only possible in the direction of junction point 5 , this has to be indicated by skipping the line $5,5,2$.

If a network has been stored previously in the memory of the computer, it does not have to be entered again by hand, but can by reloaded by number.

After the selection of the structure of the network and the number of segments, the anterograde and retrograde conduction velocities and refractory periods have to be defined. If a segment is conducting only in one direction, the parameters defining conduction velocity and refractory period in the opposite direction are of no interest.

In the example shown in figure 3.1.1. the following values for conduction time and refractoriness have been selected: 
Table 3.1.1.

\begin{tabular}{ccccc}
\hline SEGMENT & ATime & RTime & ARP & RRP \\
1 & 65 & 65 & 250 & 250 \\
2 & 35 & 35 & 250 & 250 \\
3 & 40 & 40 & 250 & 250 \\
4 & -80 & 80 & 270 & 270 \\
5 & 40 & 40 & 250 & 250 \\
6 & 20 & 20 & 240 & 240 \\
7 & 45 & 45 & 250 & 250 \\
8 & 25 & 25 & 240 & 240 \\
9 & 20 & 20 & 240 & 240 \\
\hline
\end{tabular}

Legend to table 3.1.

ATime and RTime represent the anterograde and retrograde conduction hime, ARP and RRP the anverograde and retrograde refractory period. All times are in ms.

One sees that segment number 4 representing AV Nodal conduction has been given a negative conduction time.

This has been done for two reasons:

Firstly the negative sign indicates, that the parameter is not constant, but has a rate dependent conduction time.

Secondly, the value behind the mimus sign indicates the conduction time in the first pass through the segment. At that moment, because it is the first pass, the rate at the junction point cannot be determined.

The rate dependent properties of the segment are questioned after the selection of all parameters.

To describe the relation between the rate and the conduction velocity, the two variables $a$ and $b$ in the equation

Conduction time $=a{ }^{*}$ Rate $+b$

have to be entered.

In this example the selected values are $: a=-0.2$ and $b=200$.

In the same way rate dependent refractoriness can be defined.

After the selection of the network and the electrophysiological properties of the segments, the mathematical model of the conduction system is ready to perform a simulation study.

To start such a simulation study, one or more impulses should be entered into the not activated network. To do so, two methods are presently available:

a. First one can induce a basic rhythm of a certain duration, defined by its starting point in time, its interval and its end point in time, together with the 
Junction point at which the impulses have to be entered into the network A multiple function points regular rinthris can be induced

b. Secondly one can select single stimul and use them ether combined witha basic thythm as an extra stimus or just as a single impulse

Again, multiple extra stmuli can be selected, ether at the same or at difterent Hunction poirts

The basic thythrn and the exha stmuli are finally chronologicaly listed. After every simulation cycle, (in general every minisecond), the clock of the model is conpared whe the list of ponts of the previousiy conposed. It they match, at the corresponding junction point an impulse is introduced. The conditions this impulse has to fulfil to be concucted into the segment have been described in chapter 2 . paragraph 6 .

c. Thirdy betore the actul simulation study starts, the state of one or more segments can be selected to be unequal to zero.

In that case the following parameters have to be demed:

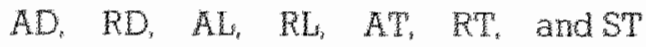

In this way one can create artificially the situation present ater the introduction of an impulse exclusively in one segment.

Although theoreticaly possible it is less useful to introduce in this way, both an anterogradely and a retrogradely conducted impulse.

The state of multple segments can be changed in this way,

In the study demonstrated in this example, the following puse train has been used.

A basic rate starting at point of time 20 , whth an interval of 600 ms has been selected introducing two impulses. These basic impulses $(t=620$ and $t=1220 \mathrm{~ms})$ are followed by one premature impulse after $1620 \mathrm{~ms}$. After a compensatory pause the regular rhythm continues after $2420 \mathrm{~ms}$.

All impulses are given at junction point 1 .

The last question to be answered is the time (in milliseconds), that the simulation process has to be continued.

After this input the program starts to simulate conduction through the network.

In most cases the following output layout has been selected:

Junction point Time of appearence Fromsegment $\mathrm{xxx} \quad \mathrm{xxx} \quad \mathrm{xxx}$

The values are shown on a monitor and/or a line printer.

Using the network described in figure 3.1.1. and the parameters listed in table 3.1.1., the reaction of the model on the above described pulse train will be demonstrated. 

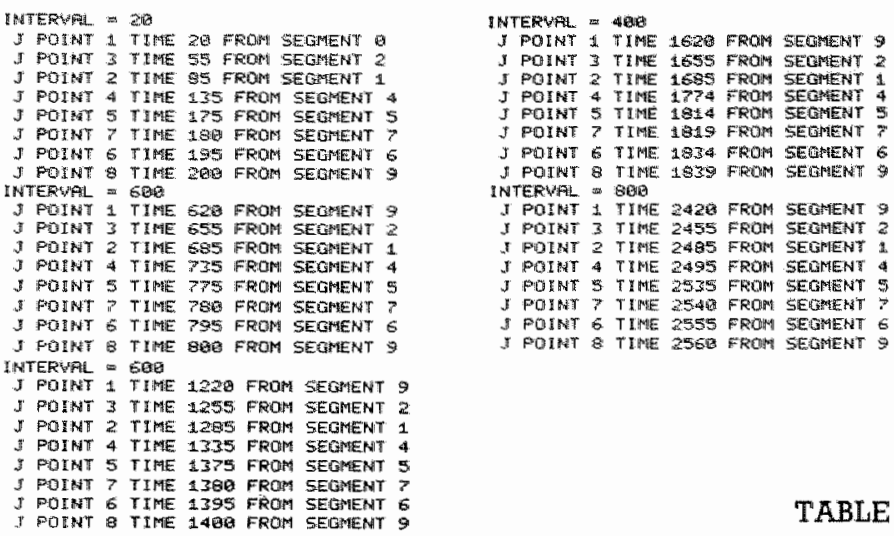

Table 3.1.2. gives the output after a simulation time of $3000 \mathrm{~ms}$.

Legend to figure 31.2

At time $1=20$ the first impulse is introduced into junction point 1 . This point represents a position bigth in the right atrum. near the sinus node. The impulse conducts through the arum, through the $A$ Wode in 80 me and over the wo buncle branches to the veninde

An $t=620$ a second impulse in introduced and conducts in the same way through the conduction system. A third impulse is given at $=1220$. At $t=1620$ a fourth impulse is introduced. This inpulse will reach 1 he $A V$ Wode with a prematurity of 200 ms This results in an A Wodal onduction time of 120 ms. The conduction through the rest of the conduction system is dentical as in the previous beats. After this premature impulse, a compensatory pause is present. So at $t=2420$, the next sinus impulse appears at juntion poin 1 . This rneasured from the previous umpulate delayed impulse will conduct fast through the AV node in $40 \mathrm{~ms}$. The rest of the conductur system is passed m the isual way

The following regular impulses will be handed like the first impulse.

NB. In thrs and following examples somethes an error of 1 ms can be observed. "The reason for this orror will be explained in chapter 4

\subsection{Cycle length alternation.}

In 1981 we studied the possible role of the AV Nodal function curve as a cause of cycle length altemation, during circus movement tachycardia. (47-48). In these publications two types of AV nodal function curves during tachcardia were used; straight lines of various gradients and representative examples of patient-based AV nodal function curves obtained during clinical electrophysiologic investigations. This was done using a mathematical model of the tachycardia circuit loaded into an Apple II microcomputer. In this model the following assumptions were made:

$A A=$ the tachycardia cycle length

$\mathrm{AH}=$ the conduction time through the AV Node and

$K=$ the conduction time through the rest of the circuit. This conduction time was assumed to be constant and rate independant.

and the following basic equation was defined:

$$
A A=A H+K
$$

The relation between the atrial rate and the $\mathrm{AV}$ Nodal conduction time - the $\mathrm{AV}$ Nodal function curve - was varied and the resulting tachycardia was studied During circus movement tachycardia a fixed point on the AV Nodal function 
curve was used, resulting in a constant tachycardia cycle length. A premature impulse given at the atrial side of the AV Node, would shorten the cycle length. This would cause an increase in conduction time through the AV Node. This prolonged conduction time, together with the constant conduction time $\mathrm{K}$ through the rest of the circuit formed the new cycle length. This cycle length would be longer than during regular tachycardia. This would cause a faster conduction through the $\mathrm{AV}$ Node. The circulating impulse arrived premature at the AV Node and so on.

To study the effect of different AV Nodal function curves upon of the tachycardia cycle length, in that model two groups of function curves were applied.

- Simple first degree polynoms representing the conduction through the AV Node as a function of the stimulus interval. Different slopes could be selected.

- Patient based AV Nodal function curves. These curves were obtained during clinical electrophysiological studies using the extra stimulus technique.

An extra stimulus was given in the atrium during a regular paced rhythm.

These patients showed cycle length alternation during these investigations.

Using a straight-line relationship between rate and conduction time, three different groups were selected.

a) Straight line AV Nodal function curves with a gradient = -1

$$
\left(\text { Slope }=45^{\circ}\right)
$$

b) Straight line AV Nodal function curves with a gradient $>-1$

$$
\text { ( Slope }<45^{\circ} \text { ) }
$$

c) Straight line AV Nodal function curves with a gradient $<-1$

$$
\text { ( Slope }>45^{\circ} \text { ) }
$$

The effect of a shortening of the stimulation interval on a tachycardia cycle was studied, using these three different groups.

Secondly patient based tunction curves were used. Similar findings could be obtained in simulation studies using these patient-based curves. The result of a perturbation of the tachycardia cycle length depended on the slope of the function curve in that point, representing the instantaneous $\mathrm{AA}$ interval.

The determination of the relation between the gradient of the AV Nodal function curve, the perturbation of the original tachycardia cycle length and the resulting cycle length alternation, has been repeated using the in chapter 2 described mathematical model of the cardiac conduction system. The results are identical as compared to the findings in the original study. 


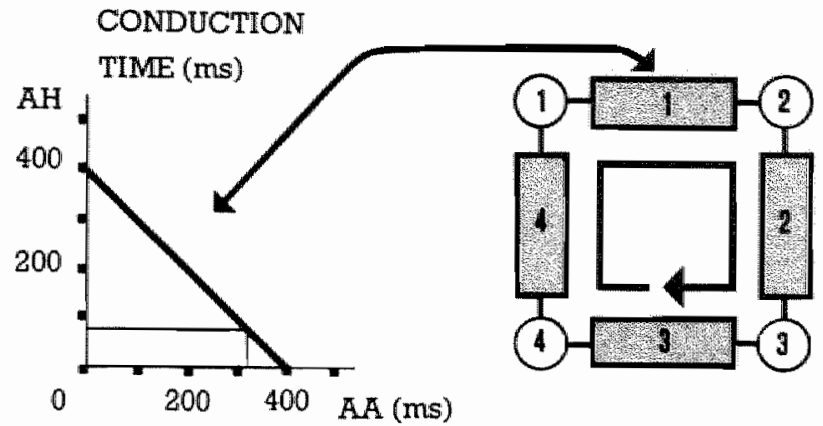

FIGURE 3.2.1.

Legend to figure 32 ?

Model representation of the study of a circus novement tachycardit is however possible to represent the

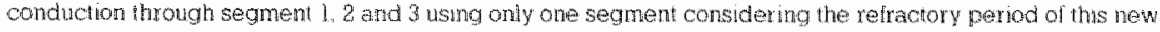
segment is longer than the conduction time though all nhee segnems together

The following network structure and electrophysiological parameters were entered.

Table 3.2.1.

\begin{tabular}{|c|c|c|c|c|c|c|c|}
\hline \multicolumn{3}{|c|}{ Definition of the network } & Segment & $\mathrm{AD}$ & $\mathrm{RD}$ & ARP & RRP \\
\hline$J P$ & Segment & $\mathbb{A} / \mathrm{K}$ & & & & & \\
\hline ] & 1 & 1 & 1 & $\mathrm{R}$ & 1.25 & 200 & 200 \\
\hline 1 & 4 & 2 & 2 & 1.25 & 1.25 & 200 & 200 \\
\hline 2 & 1 & 2 & 3 & 1.25 & 1.25 & 200 & 200 \\
\hline 2 & 2 & 1 & 4 & 1.25 & 1.25 & 200 & 200 \\
\hline 3 & 2 & 2 & & & & & \\
\hline 3 & 3 & 1 & & & & & \\
\hline 4 & 3 & 2 & & & & & \\
\hline 4 & 4 & 1 & & & & & \\
\hline
\end{tabular}

Legerd to table 32.

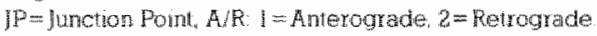

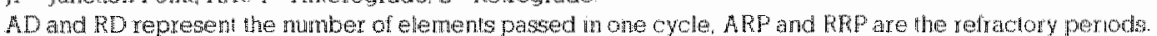

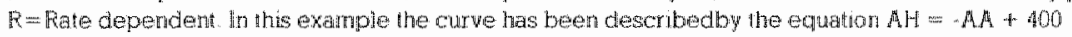

The circulating impulse is iniroduced into the circuit by changing the state and properties of one segment of the network before the simulation starts.

At position one in segment one an impulse is introduced. By introducing it exclusively in one direction in this segment, and not at the adjacent junction point. a circus movement tachycardía starts. 


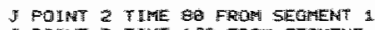
J POIHT 3 TIME 1 GQ FROEA SEQHFENT I POINT A TIME 240 FROM SEGHIENT 3 THEERVIRL $\approx 20$

J POINT $1 \mathrm{TINE} 320$ FPOM GEOMENT 4

3 POINT 2 TIME FEOM SEGMENT 1

J POINT 3 TIME 4 OU FAOM SETMETT

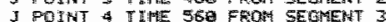

NTERUAL 260

7 POINT 1 TIMEE SER FROF SEDHEENTI

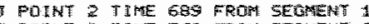

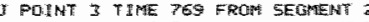

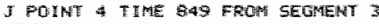

IINTESPAL $=349$

I POINT 2 IIME 929 FROMW SECMENA A

$J$ FOINT 2 TIME 994 FEOR SEGINENT 1

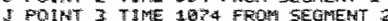

1 POINT $41 M E$ 1 125. FROH SEGMENT 3

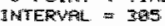

5 POINI 1 TIPE L23\% FROH SEOWENT 4

3 POINI 2 TIRT 1321 FROA SEGTENT 1

T POINT 3 TIME 1401 FROM SEGMENT

$J$ POOYNE 4 TI OOE 1481 FROM SEGMENT 3

SNTIERVAL. $=$ S2T

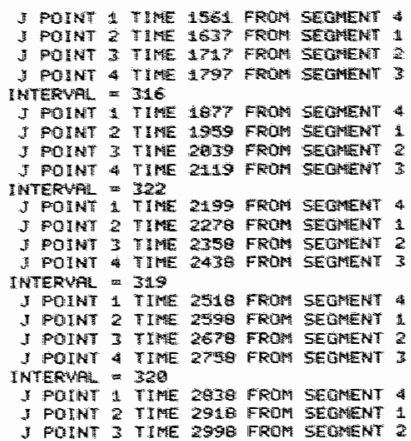

TABLE 3.2.3.

\section{CYCLE LENGTH}

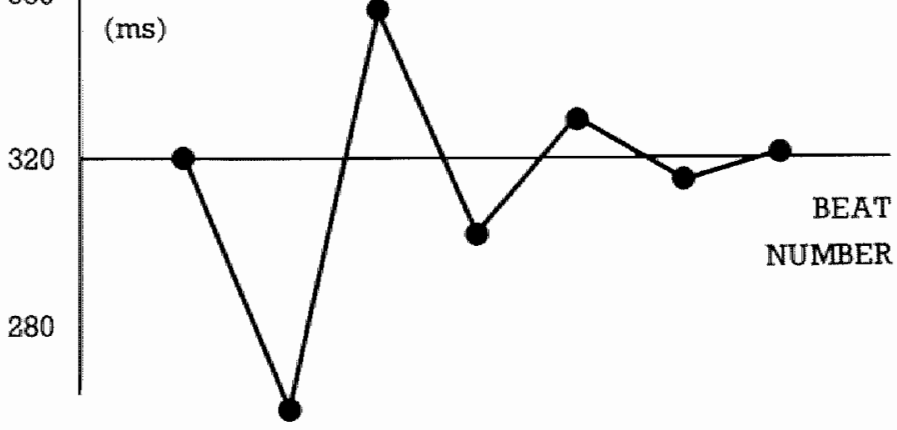

FIGURE 3.2.3.

Legend lable 323 and hgure 323

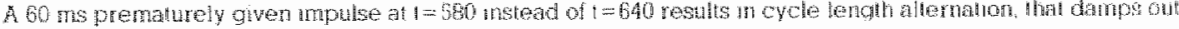
rapaly, execty as expected.

Straight line AV Nodal function curve with a gradient $<-1$.

Using the same network and parameters for the third time, the experiment has been repeated using a steep AV Nodal function curve.

With the use of this curve defined by:

$A H=-1.5 * A A+560$

the reaction of the tachycardia cycle length on a perturbation of the rate has been studied. 
LOW R.

ATRIUM
CORONARY

SINUS

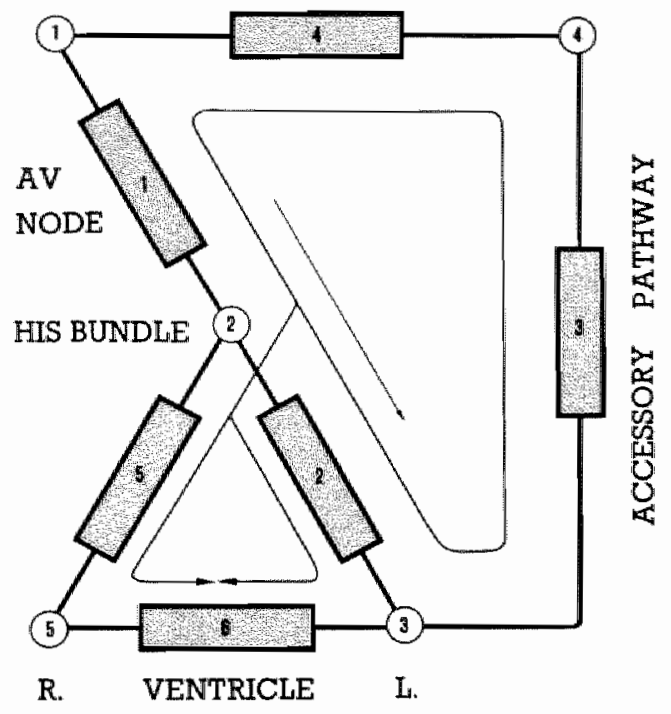

FIGURE 3.3.1.

Legend to figure 3.3.1. This figure shows the nework representing pars of the conduction systen of the hath. togeher wh an accessory pathway between the ventrote and the artum on the lef side of the heart the junction points represent the following aratomical sites: = Low Fight Atrim, $2=$ His bunde, $3=$ Len Ventricle, $4=$ Coromary Sinus, $3=$ Right Ventriche.

The segments represent: $1=$ A V Node, $2=$ Left Bundle, $3=$ Accessory Pathway. $4=$ mans Atrial Conduction, $5=$ Fioht Bundle, 6=Transseptal conduction.

The segments in this network have the following properties:

$\begin{array}{ccc}\text { Segment } & \text { ATime } & \text { RTime } \\ 1 & \mathbb{R} & 100 \\ 2 & 80 & 80 \\ 3 & 80 & 80 \\ 4 & 80 & 80 \\ 5 & 60 & 60 \\ 6 & 40 & 40\end{array}$

The refractory periods of these segments are at the begining of the study so short, that the impulse during circus movement tachycardia never finds a refractory segment in front of it. On the other hand the refractory periods are so long that they are not in conflict with the definitions given in chapter 2 paragraph 7 .

During the simulation study the influence of the duration of some refractory periods on the tachycardia will be studied. 
At the beginning of the study there is a circus movement tachycardia using segment 1 representing the AV Node, anterogradely and segment 3 , representing the accessory pathway, retrogradely.

The circusmovement tachycardia has a rate of $320 \mathrm{~ms}$, which includes an $\mathrm{AV}$ Nodal conduction time of $80 \mathrm{~ms}$

$320 \quad 240$

0

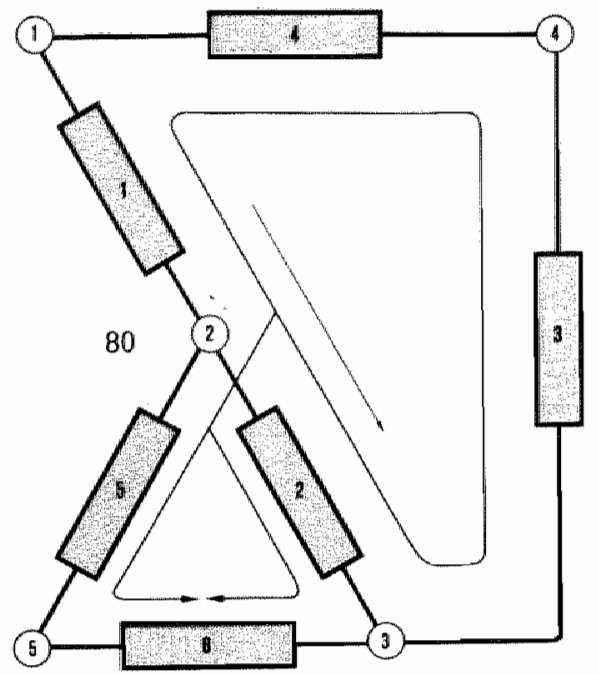

140

160

FIGURE 3.3.2.

Legend to figure 332

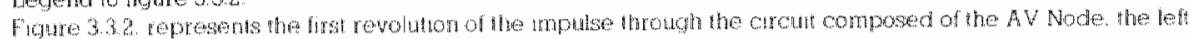

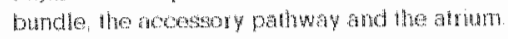


320

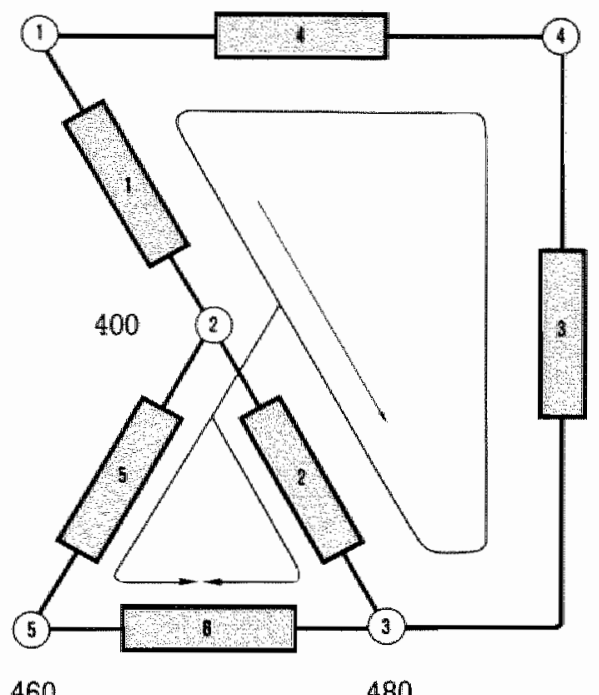

460

480

FIGURE 3.3.3.

Legerd to Tigure 33.3

Figure 3.33 shows the second revolution.

Affer 320 ms the circuit has been pessed once and the impulse stats 18 second revolution. The inpulse will conduct

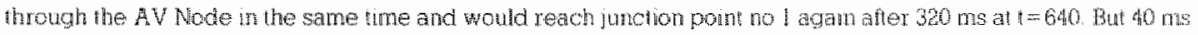
eatier, at $t=600$ a prernature impulse has been given at lunction point 1

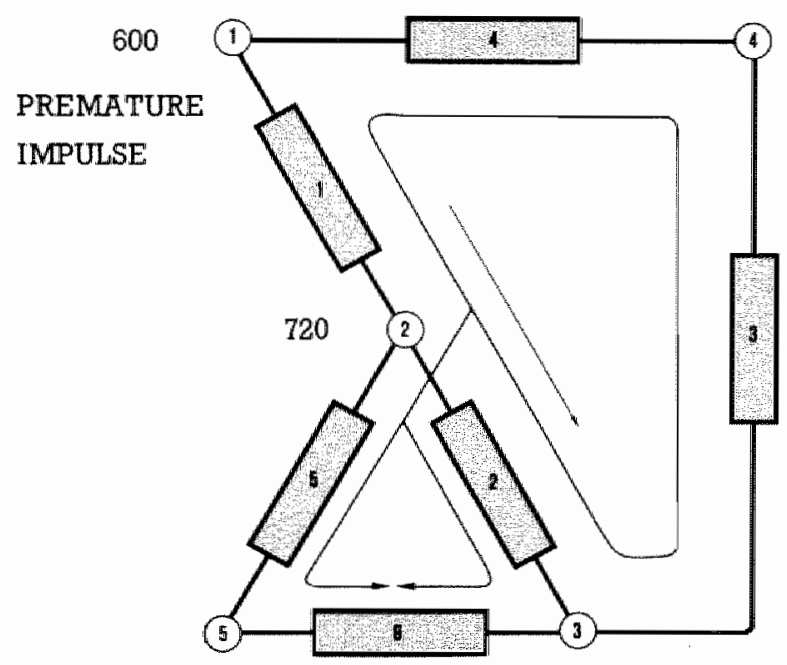

780
FIGURE 3.3.4.

Legend to fugure 3.3 . This mpulse wil conduct retrogradely through segment and collide wh the watang impulse. In antegrade direction the premature impulse will conduct though segmend 1 , representug $A v$ Nodit

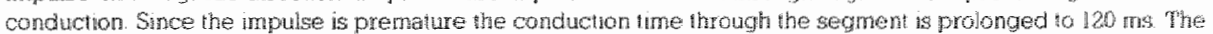

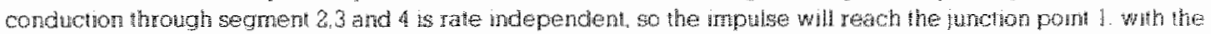
same delay of $40 \mathrm{~ms}$ 
960

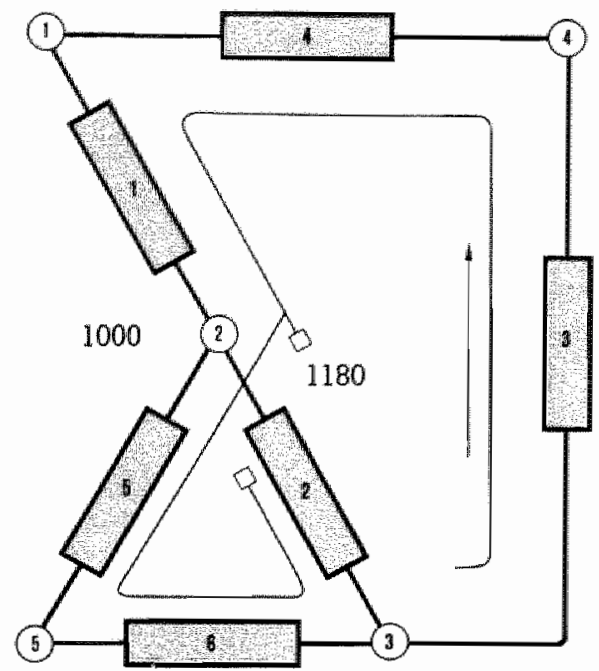

1060

1100

FIGURE 3.3.5.

Legend to figute 3.3 .5

This rasuls in a condwction time through segment 1 of 40 ms with the inpulse arriving at junction point 2 at $1=1000$ luncion poit no 2 has been activated prevously at $1=720$. th the anterograde refractory period of segment 2 is selected to be 310 ms the impulse is not able to penetrate into this segment and left bundle branch block whll occur The inpulse is able to enter segruent 5 activang the right ventricle and reaching the lef ventricle 40 ms later over the transseptal segnent.

From junction point 3, segment a is acivated retrogradely, at the same time the mupulse contimues 10 condunt through the accessory pathway retrogradely lo the atrium.

Depending on the selected refractory periods in segment no 1 and no 5 , the following situation can be simulated:

- If segment 1 is no longer refractory, the impulse will conduct retrogradely and collide with the circulating impulse

- If the relractory period of segment 5 is sufficiently short in anterograde direction, the impulse can conduct again to junction point 5 . If no block occurs in the following segments the circus movement tachycardia will be reinitiated. 


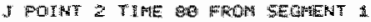

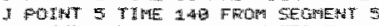
"FOTHY I TME IEO FOA SEGHEN 2

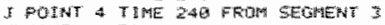

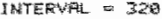

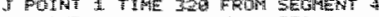
IPOCNT 2 TI

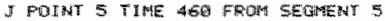

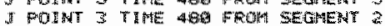

J FOINT 4 TIME 5060 FRON SEGMEAT 3

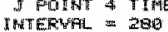

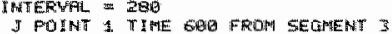

I POCINT 2 TIME 729 FROM SEGHENT 1

I FOINT ST TIME PPS FROM SEGHEAH S

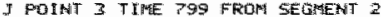

I POINT 4 THME GTO FRON SEGHTHT

MTER

3 POIATT 1 TIME SSS FROAY SECFENT 4

3 POINT 2 THIAE 1 QUBO FROM SEOMENT 1

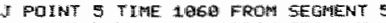

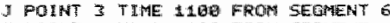

J FOINT 2 TIME 1180 FROM SEGHENT

J PPOINT 4 TINE 1AQG FHEM SEOHENT 3

INTERR WAL $=301$

3 FIOINT 1 TTME 12 TE FROM SECHENT A

I POYNT 2 TIME, 1359 FROM SEGHENT 1

3 POINT 5 TIME 1419 FIROM SEEMHENT 5

3 POINT 3 TYME 1459 FROM SEQUNENT

3 POINH 2 TIME 1539 FROM SEQMENT

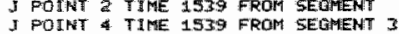

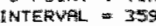

J POINT I TIME 1619 FROH SEOMENT 4

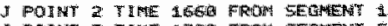

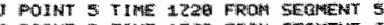

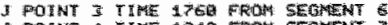

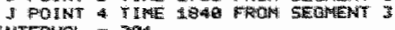

IATERWAL 3G

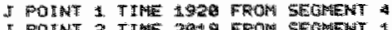

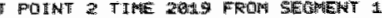

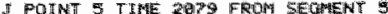

T

. Din.

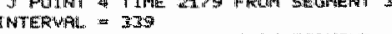

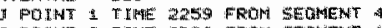

I POINT 2 TIRE ZZZZ FRON SEGMHNT I

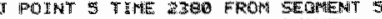

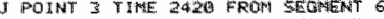

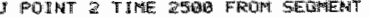

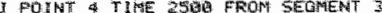

MTERVAL $=39$

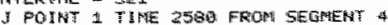

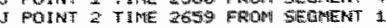

\FOINT 5 THE 2719 FROM SECMENT

- POINT 3 TIME 2759 FROM SERHENT:

II POINT 2 THPAE 28.39 FROM SEOMHENT

3 POINT 4 TIFUE 2839 FROM SEONENT 3

INTERSAL - 3 I

J PROINT 1 TIME 2519 FROM SEOAHENT 4

I: FOINT 2 TIME 2980 EROM SEQHAFNT I

POINT TIME 30.4 FROM SEOMENT S

7 POINT 3 TIME 308 FROM SEUMENT

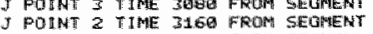

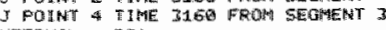

INTFRUAL 3 SHA $^{2}$
TABLE 3.3.1.

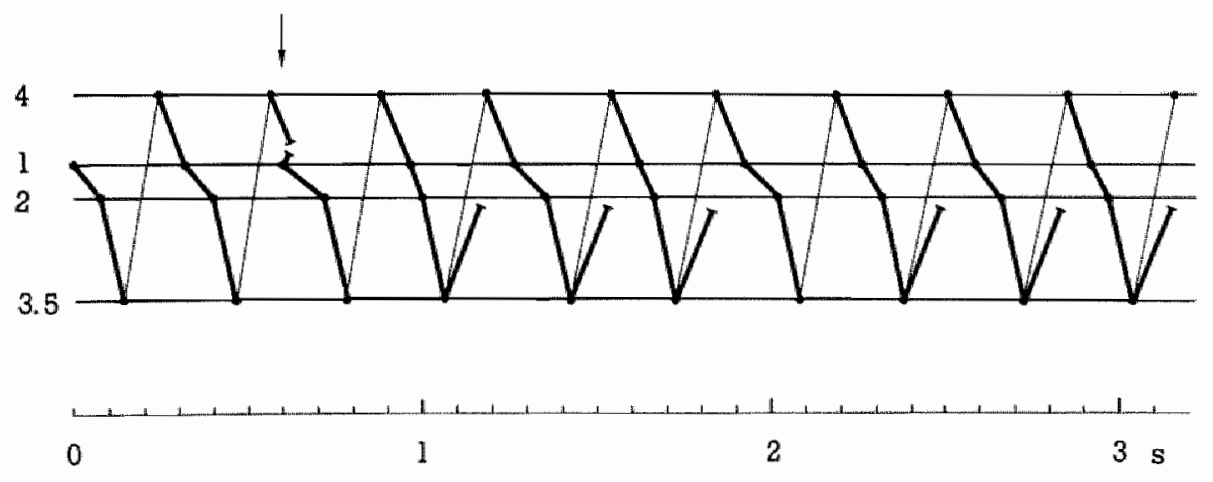

FIGURE 3.3.6.

Legend to table 3.31 . and figure 336

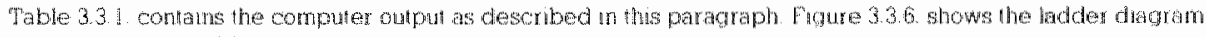
derived from this table

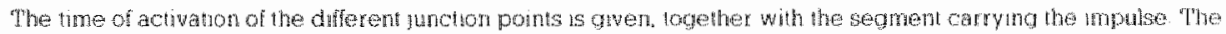

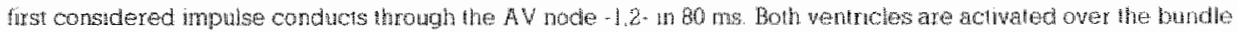

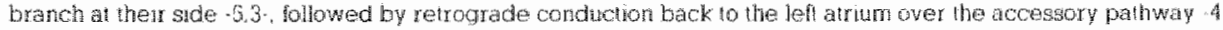

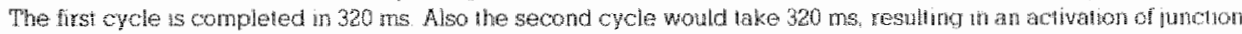

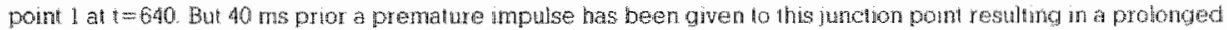

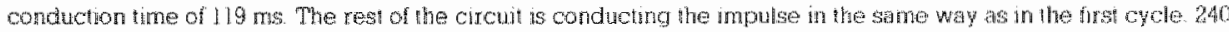

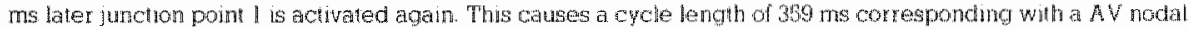

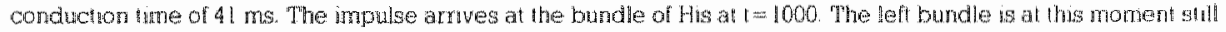

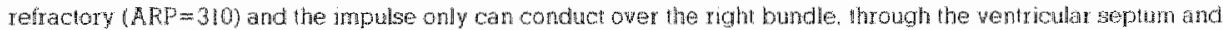
rerogractely ino the lef bundle branch. As the same fime the imptise ss conducted through the acoeswory pathwy

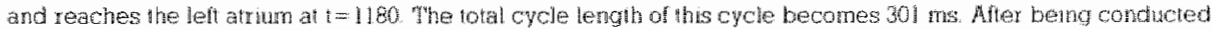

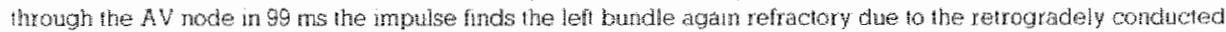

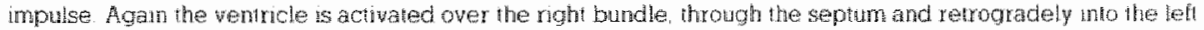
bundle. This prolongation of the AY nodal conduction also prolongs the tolai cycle length to 369 ms the AV noda conduction ine in the next cycle shortens to 4 m and the impulse is conducted again over the right bunde. Fut now the left bundle ss still refractory and does not become penetrated retrogradely in this oycle In the nexl cycte sitarung at -1920 both bundle brames are able again to conduct the mpulge anterogranely and a "nomal" cycle

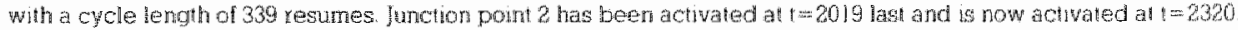
The interval is shorer as the wefactory periad of the left bunde and another beat with left bunde branch block will occur. The umpuse penetrates the left bundle brach retrogradely and junchon point 2 is reached a $1=2500$. In uhe

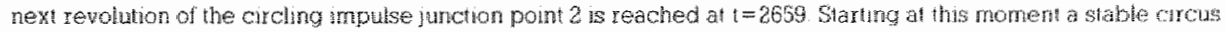
movement lachycardia with cycte lengh alternation and lef bunde branch block due to tetrograde penetratuon of the left bundle brarich is present 


\section{Chapter 4.}

\section{General discussion}

In this chapter the following subjects will be discussed:

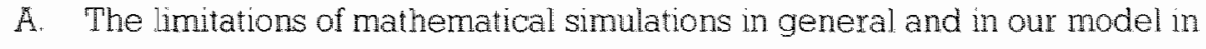
particular.

B. The relation between the time required for a complete simulation study and the resulting accuracy.

C. The problems and possibilities of the use of the model in real time during clinical electrophysiological investigations.

D. Clinical applications

E. Didactical aspects of the use of a mathematical model to simulate electrophysiological phenomena in man.

A. The limitations of mathematical simulations in general and in our model in particular.

No matter how accurately a mathematical model has been designed, simulation remains an imitation of reality.

Often many relations between different parameters are unknown or not constant in time. Nevertheless the known relations are assumed to represent the behaviour of the different parts of the model.

Every mathematical model designed for simulation purposes, has its own structure and inherent errors. The number and type of errors depends upon the details of the structure of the model. These errors are additional to those introduced because some parameters and relations between paramelers may be unknown.

In this model one of the main sources of error results from the fact that the number of elements in each segment is not unlimited. An unlimited increase in the number of elements in each segment would make it impossible to simulate even very simple processes in a short period of time.

In the present model the number of elements over which an impulse travels during one simulation cycle is calculated by dividing the number of elements in each segment (100) by the conduction time in ms.

However an impulse in this model starts at element 1 . Conduction through a segment is assumed to have finished when element 100 is reached or passed. It makes no difference whether during the last simulation cycle the impulse just reaches element 100 or passes it (and conducts to an element located more distal than this theoretically last element). This means that only 99 elements are passed in each segment. The error introduced by this fact means that the conduction time resulting from a simulation study can either be greater or smaller than the conduction time selected at the beginning of a simulation study. One way of 
controlling this error is to select conduction times less than 100 ms. Then the difference between selected and actually simulated conduction time will remam smaller than I ms per segment.

Another method to control error in calculation of conduction time is to start an impulse at element 0 . In such a situation the conduction tme calculated during the simulation study would always be equal to or longer than the interval selected at the beginming of a study

A third possible method to overcome this inaccuracy is the following. The fact that only 99 elemenis must be passed can be compensated by compensating the selected conduction limes through a segment by a factor 0.99 . The simulation lime interval derived using this correction factor is in this situation also equal to or longer than the initially selected values.

Using one of the last wo methods, the following error will occur:

If an impulse conducts through a network built of segments with rate independent conduction times, the conduction time through every segment will increase, compared to the actually selected values. The intervals in the mathematical model will vary from those in reality.

In the present model some errors in conduction time will be greater and some smaller than the ones initially selected. The accumulative effect of these errors will tend towards zero.

The following calculations illustrate the magnitude of the error introduced by these three different methods.

Using 91 different selected conduction velocities, (Vsel), starting at 1.0 element/ $\mathrm{ms}$, increasing in $0.1 \mathrm{~ms}$ steps upto 10.0 elements/ $\mathrm{ms}$, the following parameters have been calculated.

Tsel: The initially selected conduction time through the segment.

$$
T_{\text {sel }}=100 / \mathrm{Vsel}
$$

TSys99: The simulated conduction time required to conduct an impulse over 99 segments using the definitions described in chapter 2. This is the time necessary to conduct from element 1 to element 100 .

" $\mathrm{L}_{\text {sys 100: }} \quad$ The conduction time required to conduct the impulse over 100 elements.

T'sys99/100: The corrected conduction time required to conduct an impulse over 99 . The conduction velocity of the impulse has been multipied by a factor 0.99 .

Dl: $\quad$ The difference between the theoretical conduction time ${ }^{\mathrm{T}}$ sel and the simulated conduction time $\mathrm{T}_{\mathrm{Sys}} 99$

D2: The difference between the theoretical conduction time Tsel and the simulated conduction time $\mathrm{T}_{\text {sys }} 100$

D3: The difference between the conduction time Tsys99 and the corrected conduction time $\mathrm{T}_{\text {sys }} 99 / 100$ 

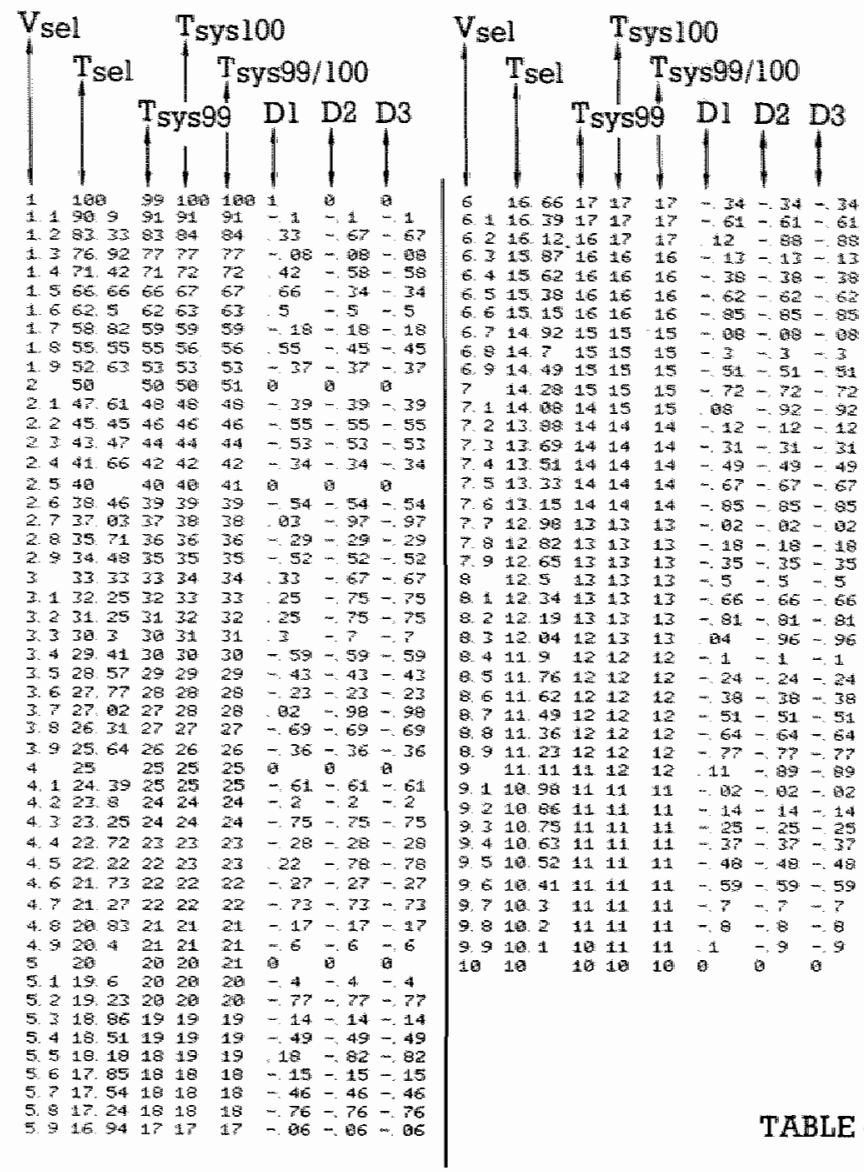

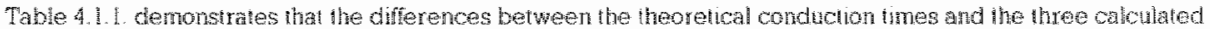
conduction times DI. D2 and D3 are always smaller than I. Th. The difference Dl can have posithe or negatre walue; the diflerences $\mathrm{D} 2$ and $\mathrm{D} 3$ only negaive values

Calculation over these 91 subsequent values gives the following mean error

$$
\begin{aligned}
& \mathrm{D} 1=0.248 \\
& \mathrm{D} 2=-0.457 \\
& \mathrm{D} 3=-0.490
\end{aligned}
$$

The average error using one of these three methodes is very small. There is a small preference for the method used in this study.

In the preceding paragraph the conduction time through a segment was assumed. to be not rate dependent. In that case the error in time to conduct through a segment and through a network will be constant.

Fig 4. 1. 1. shows an example of this situation. One sees a network containing four segments. Together they form a re-entry circuit in which an impulse is circulating clockwise. All values mentioned are derived in the direction of the circulating impulse. 


\begin{tabular}{rr|l|l} 
SEGMENT & $V_{\text {sel }}$ & $T_{\text {sel }}$ & $T_{\text {sys99 }}$ \\
\hline 1 & 1 & 100 & 99 \\
2 & 1.5 & 66.6 & 66 \\
3 & 5 & 20 & 20 \\
4 & 2 & 50 & 50
\end{tabular}

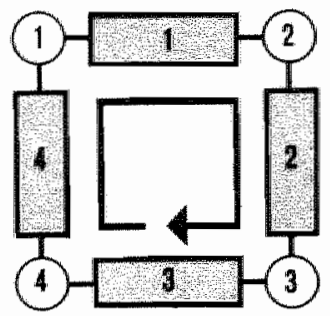

FIGURE 4.1.1.

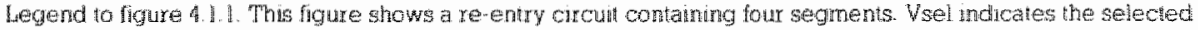
conduction velocily in alements / simulation cycle. Tsel represerts the iritially selected conduction time, and Tysg shows the conduction urne calculated by the model

Note that all corduction velocities are conshart and not rate dependent.

Time required to perform one cycle

Theoretically : $236.66 \mathrm{~ms}$

Using $\mathrm{T}_{\text {Sys }} 99: 235.00 \mathrm{~ms}$

The revolution time is slightly shortened, but remains constant.

In another example we will study the behaviour of the same network, after replacing segment l, by a segment with a rate dependant conduction time. The properties of this segment are equal to the segment used in paragraph 3.2 . 


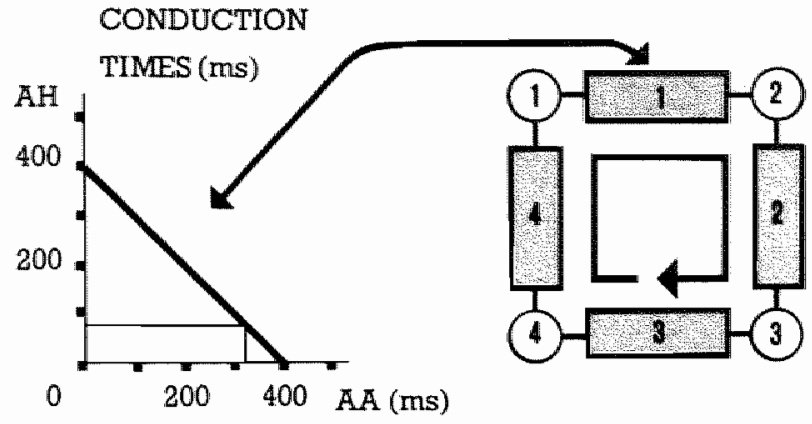

FIGURE 4.1.2.

Legend to figure 4. I.2. In this example the conduction time though segmen I is rate dependen. The relation between the rate and the conduction time is indicated in the left side of the figure.

The conduction time in the direction of the tachycardia in the other segments is as follows:

$\begin{array}{cllll}\text { Segment } & \text { ATime } & \text { RTime } & \text { AD } & \\ 1 & \text { Rate } & \text { Rate } & \text { Rate } & \text { All values } \\ & \text { Dependent } & \text { Dependent } & \text { Dependent } & \text { measured in ms. } \\ 2 & 80 & 80 & 1.25 & \\ 3 & 80 & 80 & 1.25 & \\ 4 & 80 & 80 & 1.25 & \end{array}$

Through this circuit an impulse is circulating clockwise having a revolution time of $320 \mathrm{~ms}$. By giving a premature impulse at junction point 1 , the activation interval of segment 1 shortens to $280 \mathrm{~ms}$. Immediately this will cause a prolongation of the conduction time through this segment of $40 \mathrm{~ms}$ to $120 \mathrm{~ms}$. This results in a revolution time of $359 \mathrm{~ms}$ causing an acceleration of the conduction velocity resulting in a conduction time through segment 1 of $41 \mathrm{~ms}$. Theoretically this process can continue indefinitely.

After entering this network, the conduction times and refractory periods and the previously mentioned impulses the computer will generate the following output listing. ( $t=0$ indicates the introduction of the premature impulse in segment no 1.) 
7 Fol

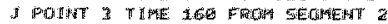

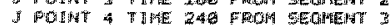

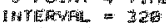

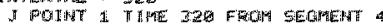
A FOH

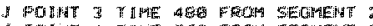

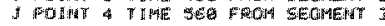

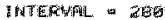

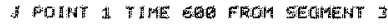

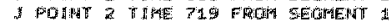

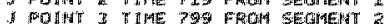

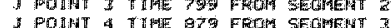
INTEREFE 359

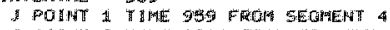
- Prallar 2 Th

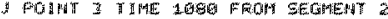

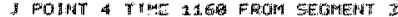

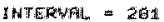

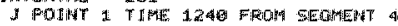

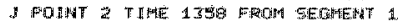
I FülNT 3 T H

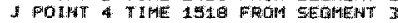
1NTERMAL $35 B$

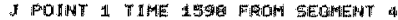

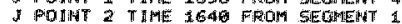

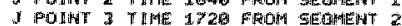

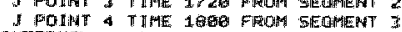

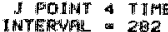

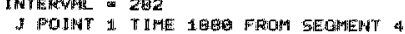
1 POINT 2 TIME 1997 FROM SEGNEHT I POINT 3: THME 2DOT ROON GEOPENT 2

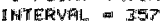

I POINT I TEME 2237 FFOH SEGMENT A J FOINT THME ZZEU FROM SEOMENT 1 I POIRT IT TIME 2360 FROM MERHIENT

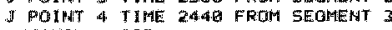
INATERVA:L $=2$ GI

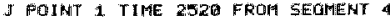
J POI INT I TIME 2536 FRCH SEGHENT 1

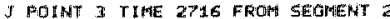
J POINT 4 TIME 2796 FRON SEIMIENT 3

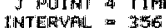

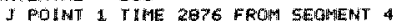

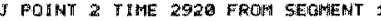

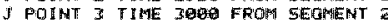
$J$ POINT \& TIME 3060 FRON SEGHEENT 3 INTERWFIL. 204

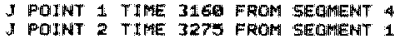
3 POINT 3 TTME 335 F FROH SEDMHENT

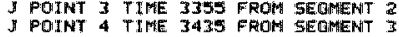
INTERWAL. - 355

3 POINT 1 TIME 351.5 FROM SEEOMERNT 4 I POINT 2 TIME 356 GROM SEGHENT 1 $J$ FOINT 3 TIME 3640 FROM SERNENT 2 J POINT 4 TIME 3TRIO FROM SEGMAENT 3 INTEAWAL 285

I POINT 1 T TME TERE FROM SEGMENT 4 $J$ POINT 2 TIME 3914 FROMI SEOMENT 1 J POINT 3 TIMUE 3994 FROM SEGMENT 2 I POINT A TTME 407 T FRDM SEGMENT 3

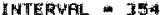

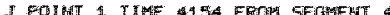

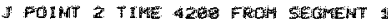

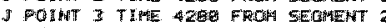

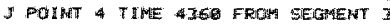

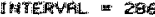

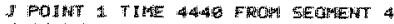

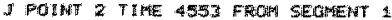

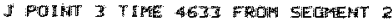

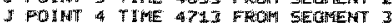

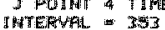

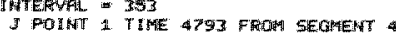

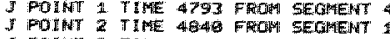

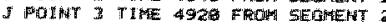

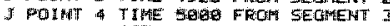

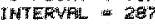

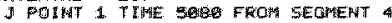

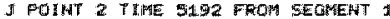
3 PEIMT 3 T MWE SOP FROM CEOHEHT I POINT 4 TINE S3S2 FROM SEGHEHT I IMTEREA 32

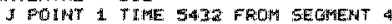

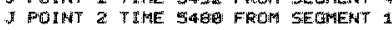

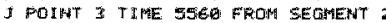

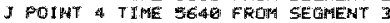
IATERYVIL $-28 \%$

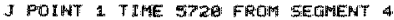

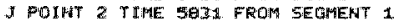

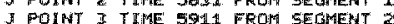

I POOUN 4 TRPE SGGI FROM SEGMENT 3 INTERYAL 351

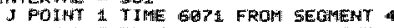
$J$ POIFT 2 ITHE GLZI FROM SEOHENT

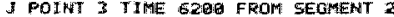

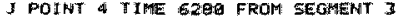
LNTERYAL 299

$J$ POIHUT 11 TI GTEO FROM SEGMENT 3 POINT 1 T1 1 THE FROM SEQMEENT 3 POINT 3 TIPF 50 FROM 5EGHEHT 3 POIHT 4 TIME 6639 FROM SEGMENT 3

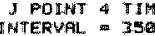

J POIFT 1 TIME 1671 T FROM SEOHENT 4 $I$ POINT 2 TI 3 POINT 3 TIME 60.40 FROM 5EGHENT 2 I POINT 4 TIME GS20 FROM SEOMENT 3 INTERYAL 290

J POINT 1. TIME TEOS FROM SEOMENT 4 $J$ POINT 2 TIPHE T109 FROM 5EOMENT 1 $J$ POINT 3 TIMUE P1:S9 FRAM SEOMENT 2 I POINT 4 TIME T2G9 FROM SEGHENT 3 INTERVAL $=349$

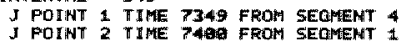
J POINT 2 TIME 7 TOQ FRON SEGMGENT 1 J POINT 4 TIME TOGQ FROM SEGMENT 3 INTERVAL $=291$

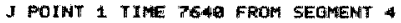
I POIMT 2 TIME 7749 FROM 5EOMENT I $J$ POINT 3 "TIME 7928 FFOM SECHMENT ? I POINT 4 TIPHE 790 FROM: SECMENT 3 INTERVAL $=340$

IPTERVAL I 34R 7. POANT 1 TIFE TSEQ FROM SEGMENT J POINT 3 TIME GIVE FRON SEGHENT 2 I POINT 4 TIME EZOO FROM SEGMENTI 3 INTIE 


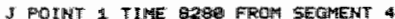

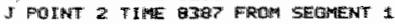

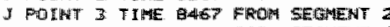
$y$ POENT 4 TIME BS4T FRTM SEIMENT 3 IANTERWALL

II POIHT 1 TIME 0627 FROA SEMAENT 4

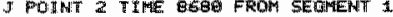

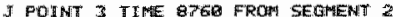

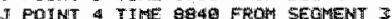
IHTECRHAL $=293$

3 POINTI 1 TIME BS20 FROM SEOMAERT 4

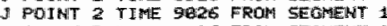

3 POIANT 3 TIME 94D FROM SEGMEEMT

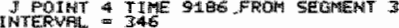

J POI ATT 1 TIHE 9266 FFOH SEOTHEMT 4

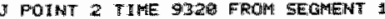

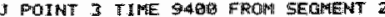

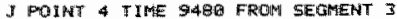

1:NTERQRL 294

3 POIMT 1 TIME 960 FROM SEIOMENT 4

I POINT 2 TIPE 9663 FRON SEOMENT 1

I POINAT 3 TIME 9?4S FRON SEGMENT ?

$I$ POINIT 4 TINAE 982S FROM SEOHENT 3

INTERWRL $=3.45$

I POINT 1 TIME 990S FROM SEGMENT A $J$ POTNT 2 T TIME 9960 FROF SEOMENT 1

J POINT 3 TIME 1 OG 4 FR FRM SEGMENT 3 POINT 4 THME 1 LI20 FROM SEGMENT 3 TTERVA 205

$J$ POIMT 1 TIME 10200 FROM SEOHENT 4 J POINT 2 TIME 16304 FROM SEOMENT 1 I POINT 3 TIHE 10384 FRQM SIEGMENT J POINIT 4 TIPE 10464 IFROMH SEGMENT 3 INTEERVAL. II 3.44

I POINT 1 TIME 1.0544 iFRON SEOMERT 4

I POINT 2 TIME 1.6OV FROM SEOMENT I

1 POINT 3 TIME 1968 FROM SEGMENT

3 POINT 4 TIME 1076 FROM SETHENT 3 TNTERVAL 2096

$J$ POINT 1 TIVE 10840 FRON SEGNENT 4

$J$ POINT 2 TIME 1094:3 FRON SEGHENIT 1

3 POIANT 3 TIME 11823 FRON SECMENIT 2

3 POINT 4 TIME 111 EI FRON SEGMENT 3 INTERVIFL $=343$

J POINT 1 THEE 111.93 FROM SEGMENT 4

J POINIT 2 TIME 1124 FROM SEGNENT I

3 OINTT 3 TIME 1.

I PEINIT 3. TME 1132G FROM SEGTART

INTERYAL \& 297

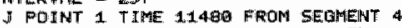

I POINT 2 TIME 115 SE FROM SEGMENT 1

I PORNT 3I TIME 116E2 FROM SEGMENT 2

3 POINT 4T THA 1.742 ROOM SEOMENT 3 INTEPUIL

$I$ POINT 1 TIME 11022 FROM SECMERT

3 POINT 2 TIME 11 1999 FROM SEGMENT 1

$J$ POINT 3 TIME 11960 FROM SEOMIENT

$J$ POINT 4 TINE 12049 FROH SEOSHENT 3

INTERVAL 290

J POINT 1 TIME 12120 FROM SELNENT A

$J$ POINT 2 TIME 12221 FROM SEMMENT 1

J POINT 3 TIPAE 12 TOA FROH SEGMENT 2

5 POINT 4 TME 12

INTERVAL $=344$
I POINT \& TINE 1Z461 FAOM SERTHENT \&

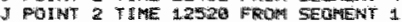

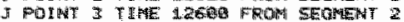
J POINT \& TIN 126 a INTERUAL 299

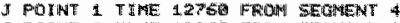

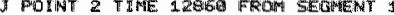

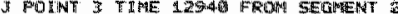

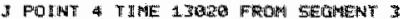
INTERYAR, 340

3 POINT 1 TINE 1 IIRT WFROM SEOHENT A

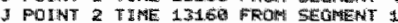

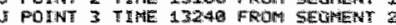

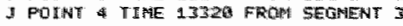
IMATERHAL $\approx 3$ EUT

J POTNT 1 TMEE 13AGA FROA SEGAREN

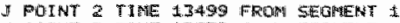

I. POINT I TINE 1337S FROMH SEOKENT

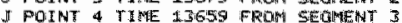
I

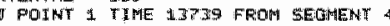

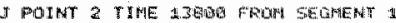

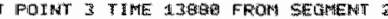
I. FOINT \& TINE 23960 FOW SEGPENT INTEIRAL $=3$ G.1

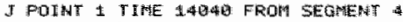

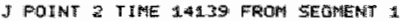

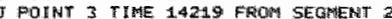

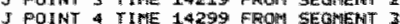
$J$ POINT
INTERVAL
JTPO

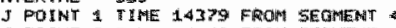

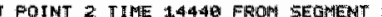

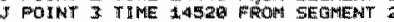
J: POINT TIME LAERG FEROH SEGMENT INTERVAL 30.2

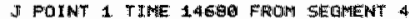
J POINT \& T TWE 14779 FRON SEGIPENT

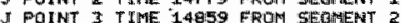

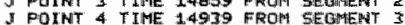

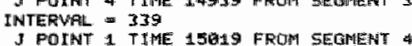

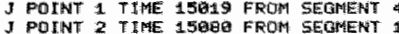
I POINT 3 THME 15160 FROM SEOHENT

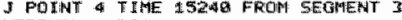
TNTERW/AL = 301

I FOINT 1 TIINE $2 \mathrm{E} 320$ FRON SEOHENT 4 1 POTNT 2 TPHE 1541 FRONA SEDRHENT 1

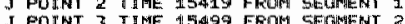
J POINT 4 TIME 15 ST FROM GEOMERT 3

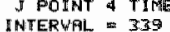

IANERWAL 339 3 POINT 2 TIME 15 ?20 FFIROM SEOMIENT 1 II POINT 3 TIME 158 IF FROM SEGNENT 2 I POIN 4 TIME 15 EQO FROM SEGMENT 3 INTERYAL $=3$ OI

J POINT 1 TIME 1596 FROM SEOMENT A

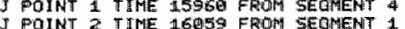
P POINT 2 TIME 160 FROM SEOMENT 2 9 PORNT 3. TIME 16.39 FROM SEGMENT 2 S POINT 4 TIME 16219 FROP SEGMBENT 3 IINTERVAL 339

J POINT : TIME 16299 FROM SEOMENT' 4 \# POINT 2 TIME 15360 FROM SEOMUNT 1

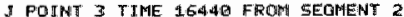

1 POTNT 4 TTME 16520 FRON STOMENT 3

T NTER"VALL $=301$

TABLE 4.1.2.

Legend to table 4.12

This reproduction of the compuer oupu shows the juncton pont reached by an mpulse, the fime of occurence and the segmen lastly used by this mpulse. 
The difference between the theoretical cycle length and the calculated one is drawn in figure 4.1.3

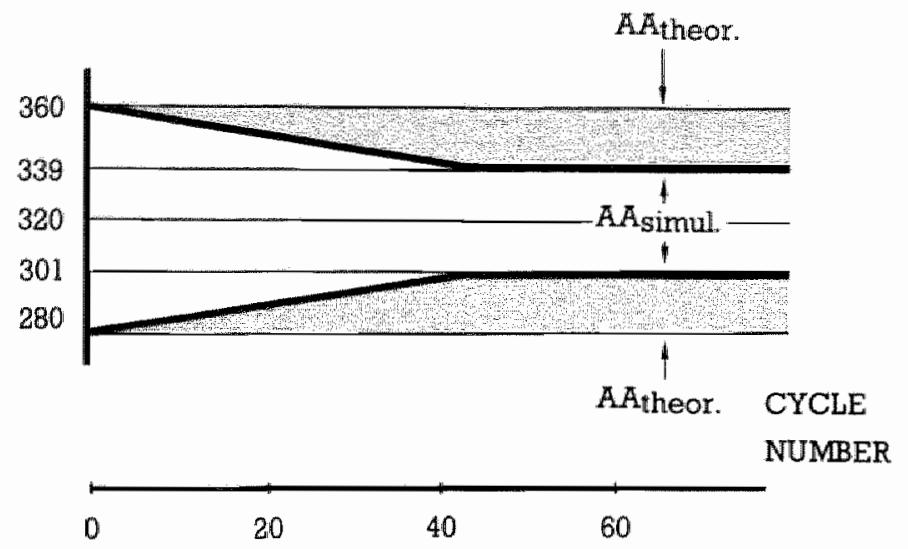

FIGURE 4.1.3.

Legend to figure 4.13

T'his figure dem nstates that the difference between the calculated samulation tirne and the theoretically selected lime interwal is not constant. As a result of a rate dependent segment in the nework, the error beween expected and simulated circuit time increases after every revolution through the network. After 16000 ms the model is stable and alternates around the thachycardia cycle length with an armplitucle of $19 \mathrm{~ms}$ and a fixed difference of $21 \mathrm{~ms}$.

B. The relation between the time required for a complete simulation study and the resultant accuracy.

The model described herein was developed using the Basic computer language and an Apple II microcomputersystem.

During the design of the model the use of this interpreter level language was selected, because program changes could be made easily. One of the big disadvantages of this interpreter level language is its relativily slow calculation velocity. To overcome this problem the model was translated from Basic to Fortran to be used on a VAX370 computer system.

Using this compiler level language instead of Basic, the calculation velocily increased by a factor of approximately 100 .

Independent of the selected computer language, the time necessary to simulate a certain process consists of two parts:

The first part indicates

a) the time to define the structure of the network,

b) the time to define the properties of the different segments and the impullses,

c) the time required to produce the results and

d) the usertime (i.e. the time elapsed while the system waits for user input).

The second part depends on

a) the number of cycles that has to be simulated,

b) the number of segments involved.

c) the state of these segments and

d) the desired accuracy. 
If one desires to increase the temporal resolution from $1 \mathrm{~ms} /$ segment to $0.1 \mathrm{~ms} /$ segment, this goal can be reached by increasing the number of elements in one segment from 100 to 1000 and by multiplying the conduction velocity by 0.1

Since this increase in accuracy will not greatly influence time for definition of the network etcetera, the total simulation time will increase by a factor smaller than 10.

Unless one wants to simulate very small segments it is seldom necessary to obtain a temporal resolution of less than $1 \mathrm{~ms}$. The inaccuracy of obtaining input data is in most cases a multiple of the error caused by the number of elements.

\section{The problems and possibilities of the use of the model in real time during clinical electrophysiological investigations}

One of the most fascinating areas to use this mathematical model is during clinical electrophysiological investigation in man. To make it possible to work in the electrophysiology laboratory the following criteria must be fulfilled. First it would be necessary to have all values required available during the study. Attempts have been made to develop computer systems to detect the potentials at different sites in the heart and to measure conduction intervals between these sites.(51) Many of these systems are able to detect reliable and reproducible potentiais during regular rhythms. None of these systems is able to provide the required intervals during the invasive electrophysiological study. During complex arrhythmias automatic calculations of intervals are unreliable and not suitable for use as input in a computer model of conduction in a real time situation.

A second condition that has to be fulfilled is the following. To be able to use the model in real time the simulation velocity must be increased. The time required to simulate a certain process has to be of the same magnitude as the process itself.

If both criteria would be fulfilled, it may be possible for instance to use the computer during the electrophysiological study of patients with tachycardia. Based on the clinical data the model could predict the effect of extra stimuli at different times and locations. These data may be of importance for terminating circus movement tachycardias. Also for the evaluation of programmable permanent pacemakers the model could be a helpful instrument.

At present the criteria required to make these applications possible have not yet been fulfilled. Hopefully in the near future it will become possible to use the model during the electrophysiological investigations as described above.

Two areas where the model can be used already with much success will be described in the following paragraphs.

\section{Clinical applications}

To initiate clinical circus movement tachycardia three conditions have to be fulfilled: 
- circuit has to be available

- Unidirectional block has to be present.

- Conduction in the circuit has to be slow enough to find excitable tissue ahead of the impulse.

In our mathematical model all these criteria can be realized. Using the model the following clinical aspects of reentrant tachycardia have been studied.

- The influence of the prematurity of the extra stimulus on initiation and termination of reentrant tachycardias. In chapter 3.3 an example of the simulation of termination of a reentrant tachycardia by giving an extra stimulus has been discussed

- The effect of the adminisiration of medication on a reentrant tachycardia. To do so the influence of this drug on the conduction velocity, ability to conduct and the refractory period of one or more segments has to be defined. Because the model has an internal clock all these parameters can be defined as being time dependent.

In chapter 3.2 the role of the AV nodal function curve as a possible cause of cycle length alternation has been discussed. In a publication describing this relation, the influence of medication on the tachycardia cycle length has also been studied.(47) By movement of the AV nodal function curve to the right, cycle length alternation could be initiated. Movement of the AV nodal function curve in this direction occurs during administration of drugs that increase $\mathrm{AV}$ nodal refractoriness. This could explain why these drugs often induce clinical cycle length alternation. Induction of cycle length alternation in the tachycardia model by gradual movement of the AV nodal refractory curve to the right tends to cause a gradual onset of alternation, with a gradual increase in amplitude. This is frequently seen in clinical cycle length alternation.

Finally the influence of the site of stimulation on initiation and termination of reentrant tachycardia can easily been studied. By decreasing the conduction velocity of a segment connecting the site of stimulation and the tachycardia circuit a greater distance can be simulated. The way a second extra impulse abbreviates the time required to terminate a tachycardia can easily be demonstrated. Recently our group published an article to illustrate the mechanisms causing this phenomenon (52).

E. Didactical aspects of the use of a mathematical model to simulate electrophysiological phenomena in man.

This model which was originally designed as an instrument for research in clinical electrophysiology, can also be used for teaching. Education by simulation models offers some important advantages to the student. Independent of the teacher the student can repeat experiments as often as wanted. With each experiment it is possible to change one or more parameters and to study the response of the model to the new conditions. 
In the present model some built-in networks are available. The student can study basic electrophysiology such as the properties of the normal cardiac conduction system, conditions required for reentry, and the initiation and termination of reentry tachycardias with programmed extrastimuli.

But these teaching facilities are not limited to the student. Also investigators can use these mathematical models as an objective judge to test their knowledge and understanding.

We believe therefore that the use of simulation models should not be limited to some areas in medicine where it has been accepted already. It deserves to be applied on a much wider scale. 



\section{Chapter 5.}

\section{Summary \\ Samenvatting \\ Rizzumee}

\section{Summary}

This study describes a mathematical model of the conduction system of the heart. Using this model it is possible to simulate reentrant tachycardias. Also the influence of extra stimuli and drugs on these tachycardias can be studied.

In this way hypotheses can be tested, concerning the mechanism of reentrant tachycardias initiated during programmed electrical stimulation of the heart. In chapter one a short introduction is given to the history of research concerning the causes of rhythm disturbances of the heart. Further a number of simulation models used in cardiac electrophysiology has been reviewed. Finally this chapter ends with an overview of the criteria this model has to fulfil.

In chapter two a description of the model is presented. It includes the layout of the model, a description of the parts (segments) used to build the model and a contemplation about the order in which the conduction of an impulse through a segment has to take place. Also in this chapter the equations describing the conduction of an impulse through a segment and the introduction of an impulse into a segment have been illustrated. Fmally the consequences of some limitations of the model are discussed.

In chapter three three simulation studies are illustrated. The simulation of the normal conduction system of the heart, followed by the simulation of a reentrant tachycardia in a patient with the WPW Syndrome. In the third study an example is given about how a hypothesis derived during clinical investigation, concerning the mechanism of the tachycardia, can be tested.

In chapter four special attention is given to the limitations of the model, its accuracy and the possibility of real time use during invasive investigations. It continues with the discussion of some clinical applications and its didactical value.

Chapter five contains the summary.

In chapter six all equations used to conduct an impulse through a segment are listed.

In chapter seven the equations related to the imtroduction of impulses into a segment are given.

\section{Samenvatting}

Deze studie beschijft een wiskundig model van het geleidingssysteem van het hart. Met behulp van dit model is het mogelijk tachycardieën op basis van reentry te simuleren. Ook kan men de invloed van extra stimuli en medicatie op deze tachycardieèn nagaan. Zo kan de onderzoeker hypotheses toetsen over het mechanisme van tachycardieën, zoals die zijn opgewekt tijdens invasief 
electrophysiologisch onderzoek bij patienten met reentry tachycardieën.

In hoofdstuk een wordt een korte inleiding gegeven over de geschiedenis van het onderzoek naar de oorzaken van ritmestoomissen van het hart.

Verder wordt een overzicht gegeven van een aanial in de cardiale electrophysiologie gebruikte simulatiemodellen. Het hoofdstuk wordt afgesloten met een omschrijving van de eisen waaraan het in dit proefschrift omschreven model dient te voldoen.

In hoofdstuk twee volgt een beschrijving var het model. Aan de orde komen de opbouw van het model, een beschrijving van de bouwstenen (segmenten) waaruit het model is samengesteld en een beschouwing betreffende de volgorde waarin de voortgelleiding door deze segmenten plaatsvindt. Tevens wordt aangegeven volgens welke wetten de voortgeleiding van een impuls door een segment geregeld is, alsmede hoe nieuwe impulsen in de segmenten kunnen worden geintroduceerd. Tenslotte worden de consequenties van een tweetal beperkingen van het model gedemonstreerd.

In hoofdstuk drie worden drie simulatiestudies besproken, te weten de simulatie van het normale geleidingssysteem van het hart, gevolgd door de simulatie van een cirkel tachycardie in een patient met het WPW syndroom. In het derde voorbeeld wordt gedemonstreerd hoe een op grond van klinisch onderzoek ontstane hypothese betreffende het aan een tachycardie ten grondslag liggende mechanisme kan worden getoetst. In hoofdstuk vier wordt aandacht besteed aan de beperkingen van het model, de nauwkeurigheid die ermee bereikt kan worden alsmede de mogelijkheden om het model tijdens het invasief onderzoek te gebruiken. Verder komen een aantal klinische toepassingen aan de orde alsmede het gebruik wan het model als onderwijsmiddel

Hoofdstuk vijf bevat de samenvatting.

Hoofdstuk zes geeft een overzicht van alle vergelijkingen, die gebruikt worden bij de geleiding van een impuls door een segment.

In hoofdstuk zeven worden de vergelijkingen gegeven, die bij het introduceren van een nieuwe impuls in een van de segmenter van het model worden toegepast.

\section{Rizzumee}

Dit beukske eksplikeert un wiskunstig medèl vaan ut geleijingssiesteem vaan ut hart. Met behöllep vaan dit medel is ut meugelik um tachycardieen op basis vaan reentry te simulere. Aoch is ut meugelik de oetwerreking vaan vreuger kaomende hartsleeg en medikaminte op dees tachycardieën noa te kieke. Zoe kin den oonderzéuker hiepotese sjekke euver ut mekaniek vaan tachycardieën, wie die weure opgewèk bei inwendig elektrofiesiologies oonderzeuk bei luij mèt reentrytachycardieen.

In sjapiter ein weurd unne korte inleijing gegeeve euver de gesjiedenis vaan ut oonderzeuk nao oerzaake vaan hartkloppinge. Weijer weurd un euverzieg gegeeve vaan un aontal in de elektrofiesiologie vaan ut hart gebrunkde simulaasie medèlle. Ut sjapiter weurd aofgesloote mèt un besjrijving vaan vereiste boeaon ut in dit beukske besjreeve medel moot voldoen.

In sjapiter twie steit un besjrijving vaan ut medel. Daorin weurde geneump de samestelling vaan ut medel, un besjrijving vaan de oonderdeile (segminte) boe 
oet ut medel besteit, en un fielezofie euver de vollegorde boe in de geleijing door dees segminte verlop. Aoch weurd verduts wie de geleijing vaan unnen impuls door zoen segmint geregeld is en wie impulse in de segminte weure ingeveurd. Aon ut ind weure de konsekwinsies vaan twie beperrekinge vaan ut medèl oetgellag.

In sjapiter drei weure drei simulaasieaonderzeuke geëxplikeerd, naomelik de simulaasie vaan ut gewoene geleijingssiesteem vaan ut hart, dan de simulaasie vaan unne sirrekel tachycardie vaan unne mins met de krenkde vaan Wolff. Parkinson en White. In ut derde veurbeeld weurd getuind wie me unne hiepotese kin sjekke dee oontstande is nao aonleijing vaan klimies oonderzeuk noa ut mekaniek vaan hartkloppinge.

In sjapiter veer weurd aondach geweijd aon de beperrekinge vaan ut medel, wie perseis ut medel werrek en aoch of ut meugelik is beij inwendig oonderzeuk ut medel touw te passe. Weijer weure un aontal kliniese touwpassinge geëksplikeerd en aoch of ut medel in ut onderwies gebruuk kin weure.

Sjapiter veif bevat dun rizzumee.

Sjapiter zes gief un euverziech vaan alle wiskunstige vergeliekinge die gebruuk weure beij de geleijing vaan unnen impuls door un segmint.

In sjapiter zeve weurde de vergeliekinge gegeeve die weure gebruuk beij de introduksie vaan unnen neuje impuls in ein vaan de segminte vaan ut medèl. 


\section{Chapter 6.}

\section{Appendix I: Handling of a segment}

The following equations summarize the handling of the 35 different states if no external impulses are entered into the segment and conduction velocity and refractory period remain constant.

$A P_{n}, R P_{n}, A L_{n} \ldots$ determine the state in the $n^{\text {th }}$ simulation cycle.

$A P_{n+1}, R P_{n+1}, A L_{n+1} \ldots$ determine the state in the $(n+1)^{\text {th }}$ simulation cycle.

$\mathrm{ST}_{\mathbb{n}} 1, \mathrm{ST}_{\mathrm{n}} 2, \mathrm{ST}_{\mathrm{n}} 3$ etc represent State $1,2,3$ etc during the $(\mathrm{n})^{\text {th }}$ simulation cycle.

ST 1. $A P_{n}=0 R P_{n}=0 A L_{n}=0 R L_{n}=0 A T_{n}=0 R T_{n}=0 C_{n}=0$

$A P_{n+1}=0 R P_{n+1}=0 A L_{n+1}=0 R L_{n+1}=0 A T_{n+1}=0 R T_{n+1}=0 \mathrm{CP}_{n+1}=0$ $\mathrm{ST}_{\mathrm{n}+1}=\mathrm{ST} 1$

ST 2. $A P_{n}>0 R P_{n}=0 A L_{n}=0 R L_{n}=0 A T_{n}>0 R T_{n}=0 C_{n}=0$

$R P_{n+1}=0 A L_{n+1}=0 R L_{n+1}=0 R T_{n+1}=0 C P_{n+1}=0$

$A P_{n+1}=A P_{n}+A D$

IF $\left(A P_{n+1} \geqslant 100\right)$

THEN : $A P_{n+1}=0 \quad$ ELSE : $A P_{n+1}=A P_{n+1}$

$\mathrm{ST}_{\mathrm{n}+1}=\mathrm{ST} 3 \quad \mathrm{ST}_{\mathrm{n}+1}=\mathrm{ST} 2$

$A T_{n+1}=A T_{n}-1$

ST 3. $A P_{n}=0 R P_{n}=0 A L_{n}=0 R L_{n}=0 A T_{n}>0 R T_{n}=0 C_{n}=0$

$A P_{n+1}=0 R P_{n+1}=0 R L_{n+1}=0 R_{n+1}=0 \mathrm{CP}_{n+1}=0$

$A T_{n+1}=A T_{n}-1$

IF $\left(\mathrm{AT}_{\mathrm{n}+1}=0\right)$

THEN : $A L_{n+1}=1$

$\mathrm{ST}_{\mathrm{n}+1}=\mathrm{ST} 4$

ELSE: $: L_{n+1}=0$

$\mathrm{ST}_{\mathrm{n}+1}=\mathrm{ST} 3$ 
ST 4. $A P_{n}=0 R P_{n}=0 A L_{n}>0 R L_{n}=0 A T_{n}=0 R T_{n}=0 \mathrm{CP}_{n}=0$

$A P_{n+1}=0 R P_{n+1}=0 R L_{n+1}=0 A T_{n+1}=0 R T_{n+1}=0 C P_{n+1}=0$

$A L_{n+1}=A L_{n}+A D$

IF $\left(A L_{n+1} \geqslant 100\right)$

THEN: $A L_{n+1}=0 \quad$ ELSE: $A L_{n+1}=A L_{n+1}$

$\mathrm{ST}_{\mathrm{n}+1}=\mathrm{ST} 1 \quad \mathrm{ST}_{\mathrm{n}+1}=\mathrm{ST} 4$

ST 5. $A P_{n}>0 R P_{n}=0 A L_{n}>0 R L_{n}=0 A T_{n}>0 R T_{n}=0 C_{n}=0$

$R P_{n+1}=0 R L_{n+1}=0 R T_{n+1}=0 C P_{n+1}=0$

$A P_{n+1}=A P_{n}+\mathscr{A}_{2} \mathrm{D}$

$A L_{n+1}=A L_{n}+A D$

IF $\left(A L_{n}+1 \geqslant 100\right)$

THEN: $A L_{n+1}=0 \quad$ ELSE: $A L_{n+1}=A L_{n+1}$

$\mathrm{ST}_{\mathrm{n}+1}=\mathrm{ST} 2 \quad \mathrm{ST}_{\mathrm{n}+\mathrm{l}}=\mathrm{ST} 5$

$\mathrm{AT}_{\mathrm{n}+1}=\mathrm{AT}_{\mathrm{n}}-1$

ST 6. $A P_{n}=0 R P_{n}>0 A L_{n}=0 R L_{n}=0 A T_{n}=0 R T_{n}>0 \mathrm{CP}_{n}=0$

$A P_{n+1}=0 A L_{n+1}=0 R L_{n+1}=0 A T_{n+1}=0 \mathrm{CP}_{n+1}=0$

$R P_{n+1}=R P_{n}-R D$

IF $\left(R_{n+1} \leqslant 1\right)$

"THEN: $R P_{n+1}=0$

$S T_{n+1}=S T 7$

ELSE: $R P_{n+1}=R P_{n+1}$

$\mathrm{ST}_{\mathrm{n}+1}=\mathrm{ST} 6$

$\mathrm{RT}_{\mathrm{n}+1}=\mathrm{RT}_{\mathrm{m}}-\mathrm{I}$

ST 7. $A P_{n}=0 R P_{n}=0 A L_{n}=0 R L_{n}=0 A T_{n}=0 R_{n}>0 \mathrm{CP}_{n}=0$

$A P_{n+1}=0 R P_{n+1}=0 A L_{n+1}=0 A T_{n+1}=0 \mathrm{CP}_{n+1}=0$

$\mathrm{RT}_{\mathrm{n}+\mathrm{l}}=\mathrm{RT}_{\mathrm{n}}-\mathrm{l}$

IF $\left(\mathrm{RT}_{\mathrm{n}+1}=0\right)$

THEN : $\mathrm{RL}_{n+1}=100$

$S T_{n+1}=S T$

ELSE: $R L_{n+1}=0$

$\mathrm{ST}_{\mathrm{n}+1}=\mathrm{ST} 7$ 
ST 8. $A P_{n}=0 \mathrm{RP}_{\mathrm{n}}=0 \mathrm{AL}_{\mathrm{n}}=0 \mathrm{RU}_{\mathrm{n}}>0 \mathrm{AT}_{\mathrm{n}}=0 \mathrm{RT}_{\mathrm{n}}=0 \mathrm{CP}=0$

$$
\begin{aligned}
& A P_{n+1}=0 R P_{n+1}=0 A L_{n+1}=0 A T_{n+1}=0 R T_{n+1}=0 C P_{n+1}=0 \\
& R L_{n+1}=R L_{n}-R D
\end{aligned}
$$

IF $\left(\mathrm{RL}_{\mathrm{n}+1} \leqslant 1\right)$

$$
\begin{aligned}
& \text { THEN : } R L_{n+1}=0 \\
& \mathrm{ST}_{\mathrm{n}+1}=\mathrm{ST} \\
& \text { ELSE: } \quad \operatorname{RL}_{n+1}=\mathbb{R L}_{n+1} \\
& S T_{n+1}=S T \text { \& }
\end{aligned}
$$

ST 9. $A P_{n}=0 R_{n}>0 A L_{n}=0 R_{n}>0 A T_{n}=0 R T_{n}>0 C P_{n}=0$

$$
\begin{aligned}
& A P_{n+1}=0 A L_{n+1}=0 A T_{n+1}=0 C P_{n+1}=0 \\
& R P_{n+1}=R P_{n}-R D \\
& R L_{n+1}=R L_{n}-R D
\end{aligned}
$$

$\operatorname{IF}\left(\mathrm{RL}_{\mathrm{n}+1} \leqslant 1\right)$

$$
\begin{aligned}
& \text { THEN : } R L_{n+1}=0 \quad \text { ELSE: } R_{n+1}=R_{n+1} \\
& \mathrm{ST}_{\mathrm{n}+\mathrm{l}}=\mathrm{ST}^{6} \quad \mathrm{ST}_{\mathrm{n}+\mathrm{l}}=\mathrm{ST}^{\mathrm{g}}
\end{aligned}
$$

$\mathrm{RT}_{\mathrm{n}+\mathrm{l}}=\mathrm{RT}_{\mathrm{n}}-1$

ST 10. $\mathrm{AP}_{\mathrm{n}}>0 \mathrm{RP}_{\mathrm{n}}>0 \mathrm{AL}_{\mathrm{n}}=0 \mathrm{RL}_{\mathrm{n}}=0 \mathrm{AT}_{\mathrm{n}}>0 \mathrm{RT}_{\mathrm{n}}>0 \mathrm{CP}=0$

$$
A L_{n+1}=0 R L_{n+1}=0
$$

IF $\left(\left(\mathrm{RP}_{\mathrm{n}}-\mathrm{AP}_{\mathrm{n}}\right) \leqslant(\mathrm{AD}+\mathrm{RD})\right)$

$$
\begin{aligned}
& \text { THEN : } A P_{n+1}=0 \\
& \text { ELSE: } A_{n+1}=A P_{n+1}+A D \\
& R P_{n+1}=0 \\
& R P_{n+1}=R P_{n+1}-R D \\
& C P_{n+1}=A P_{n}+A D^{*} P D \\
& \mathrm{ST}_{\mathrm{n}+\mathrm{l}}=\mathrm{ST} 11 \\
& \mathrm{CP}_{\mathrm{n}+1}=0 \\
& \mathrm{SP}_{\mathrm{n}+1}=\mathrm{ST} 10 \\
& A T_{n+1}=A_{n} T_{n}-1 \\
& \mathrm{RT}_{\mathrm{n}+1}=\mathrm{RT}_{\mathrm{n}}-1
\end{aligned}
$$


ST 11. $A P_{n}=0 R P_{n}=0 A L_{n}=0 R L_{n}=0 A T_{n}>0 R_{n}>0 C P_{n}>0$

$$
\begin{aligned}
& A P_{n+1}=0 R_{n+1}=0 C P_{n+1}>0 \\
& A T_{n+1}=A T_{n}-1 \\
& \text { IF }(A T+1=0) \\
& \text { THEN: } A_{n+1}=1 \\
& \mathrm{ST}_{\mathrm{n}+1}=\mathrm{SI} 12 \quad \mathrm{ST}_{\mathrm{n}+1}=\mathrm{ST} \| \\
& \mathrm{RT}_{\mathrm{n}+1}=\mathrm{RT}_{\mathrm{n}}-1 \\
& \text { IF }\left(\mathrm{RrT}_{\mathrm{n}+1}=0\right) \\
& \text { THEN: } \quad R L_{n+1}=100 \\
& \mathrm{ST}_{\mathrm{n}+1}=\mathrm{ST}_{\mathrm{n}+1} \text {. }
\end{aligned}
$$

IF $\left(\mathrm{ST}_{\mathrm{n}+1}=\mathrm{ST} 12\right)$

THEN : $\mathrm{ST}_{\mathrm{n}+1}=\mathrm{ST} 18 \quad$ ELSE: $: \mathrm{ST}_{\mathrm{n}+1}=\mathrm{ST} 13$

$\mathrm{ST}^{\mathrm{n}}$ 12. $A \mathrm{P}_{\mathrm{n}}=0 \mathrm{RP}_{\mathrm{n}}=0 \mathrm{AL}_{\mathrm{n}}>0 \mathrm{RL_{ \textrm {n } }}=0 \mathrm{AT}_{\mathrm{n}}=0 \mathrm{RT}_{\mathrm{n}}>0 \mathrm{CP} \mathrm{P}_{\mathrm{n}}>0$

$$
\begin{aligned}
& A P_{n+1}=0 P_{n+1}=0 A_{n+1}^{r} P_{n+1}=0 P_{n+1}>0 \\
& A L_{n+1}=A L_{n}+A D \\
& \operatorname{IF}\left(A L_{n+1} \geqslant C P_{n}\right) \\
& \text { THEN: } \mathrm{AL}_{n+1}=0 \\
& \mathrm{ST}_{\mathrm{n}+1}=\mathrm{ST} 14 \\
& \text { ELSE: } A L_{n+1}=A L_{n+1} \\
& S T_{n+1}=S T 12 \\
& \mathrm{RT}_{\mathrm{n}+1}=\mathrm{RT}_{\mathrm{n}}-1 \\
& \text { If }\left(\mathrm{RT}_{\mathrm{n}+1}^{\mathrm{n}}=0\right) \\
& \text { THEN: } R L_{n+1}=100 \\
& S T_{n+1}=S T n+1
\end{aligned}
$$

$\mathrm{IF}\left(\mathrm{ST}_{\mathrm{T}}+\mathrm{I}=\mathrm{ST} 14 \mathrm{~s}\right.$

THEN:ST $\mathrm{ST}_{\mathrm{n}+1}=\mathrm{ST} 16 \quad \mathrm{ELSE}: \mathrm{ST}_{\mathrm{n}+1}=\mathrm{ST} 18$ 
ST 13. $A P_{n}=0 R P_{n}=0 A L_{n}=0 R L_{n}>0 A T_{n}>0 R T_{n}=0 C_{n}>0$

$A P_{n+1}=0 R P_{n+1}=0 R T_{n+1}=0 C P_{n+1}>0$

$R L_{n+1}=R L_{n}-R D$

IF $\left(\mathrm{RL}_{\mathrm{n}+1} \leqslant \mathrm{CP}\right)$

THEN : $R L_{n+1}=0$

$\mathrm{ST}_{\mathrm{n}+1}=\mathrm{ST} 15$

ELSE: $R_{n+1}=R L_{n+1}$

$\mathrm{ST}_{\mathrm{n}+1}=\mathrm{ST} 13$

$A T_{n+1}=\mathbb{A} T_{n}-1$

$\operatorname{IF}\left(A T_{n+1}=0\right)$

THEN: $A L_{n+1}=1$

ELSE: $A L_{n+1}=0$

$\mathrm{ST}_{\mathrm{n}+1}=\mathrm{ST}_{\mathrm{n}+1}$

$\mathrm{IF}(\mathrm{STM}+]=\mathrm{ST} 15)$

THEN $: \mathrm{ST}_{\mathrm{n}+1}=\mathrm{ST} 17 \quad$ ELSE $: \mathrm{ST}_{\mathrm{n}+1}=\mathrm{ST} 18$

ST 14. $A P_{n}=0 R P_{n}=0 A L_{n}=0 R L_{n}=0 A T_{n}=0 R T_{n}>0 \mathrm{CP}_{n}>0$

$A P_{n+1}=0 R P_{n+1}=0 A L_{n+1}=0 A T_{n+1}=0 C P_{n+1}>0$

$R T_{n+1}=R T_{n}-1$

IF $\left(\mathrm{RT}_{\mathrm{n}+1}^{\mathrm{n}}=0\right)$

THEN : $R L_{n+1}=100$

$\mathrm{ST}_{\mathrm{n}+1}=\mathrm{ST} 16$

ELSE: $R L_{n+1}=0$

$\mathrm{ST}_{\mathrm{n}+1}=\mathrm{ST} 14$

ST 15. $A P_{n}=0 R P_{n}=0 A L_{n}=0 R L_{n}=0 A T_{n}>0 R T_{n}=0 C P_{n}>0$

$\mathbb{A} P_{n+1}=0 R P_{n+1}=0 R L_{n+1}=0 R T_{n+1}=0 C P_{n+1}>0$

$A T_{n+1}=A T_{n}-1$

$\operatorname{IF}\left(A T_{n+1}=0\right)$

THEN: $A L_{n+1}=1$

$\mathrm{ST}_{\mathrm{n}+1}=\mathrm{ST} 17$
ELSE: $A L_{n+1}=0$

$\mathrm{Srn}_{\mathrm{n}+1}=\mathrm{ST} 15$

ST 16. $A P_{n}=0 R P_{n}=0 A L_{n}=0 R L_{n}>0 A T_{n}=0 R T_{n}=0 C P_{n}>0$

$A P_{n+1}=0 R P_{n+1}=0 A L_{n+1}=0 A T_{n+1}=0 R T_{n+1}^{1}=0 C P_{n+1}>0$

$R L_{n+1}=R L_{n}-R D$

IF $\left(R L_{n+1} \leqslant C P_{n}\right)$

THEN : $R L_{n+1}=0$

$\mathrm{ST}_{\mathrm{n}+1}=\mathrm{ST} 19$

ELSE: $R L_{n+1}=0$

$\mathrm{ST}_{\mathrm{n}+1}=\mathrm{ST} 16$ 
ST 17. $A P_{n}=0 R P_{n}=0 A_{n}>0 \mathrm{RL}_{n}=0 \mathrm{AT}_{\mathrm{n}}=0 \mathrm{RT}_{\mathrm{n}}=0 \mathrm{CP}=0$

$$
\begin{aligned}
& A P_{n+1}=0 R P_{n+1}=0 R L_{n+1}=0 A T_{n+1}=0 R_{n+1}=0 C P_{n+1}>0 \\
& A_{n+1}=A L_{n}+A D \\
& \text { IF }\left(A_{1} L_{n+1} \geqslant C P\right) \\
& \text { THEN: } A L_{\mathrm{n} H}=0 \\
& \mathrm{ST}_{n+1}=\mathrm{SP} 19 \\
& \text { ELSE: } A L_{n+1}=A L_{n+1} \\
& S T_{n+1}=S T 17
\end{aligned}
$$

ST 18. $A P_{n}=0 R P_{n}=0 A L_{n}>0 R L_{n}>0 A T_{n}=0 R T_{n}=0 C P_{n}>0$

$$
\begin{aligned}
& A P_{n+1}=0 R P_{n+1}=0 A T_{n+1}=0 R T_{n+1} C P_{n+1}>0 \\
& A_{n+1}=A L_{n}+A D \\
& \text { IF }\left(A_{n+1} \geqslant C P_{n}\right) \\
& \text { THEN: } A L_{n+1}=0 \text { ELSE: } A L_{n+1}=A L_{n+1} \\
& \mathrm{ST}_{\mathrm{n}+1}=\mathrm{ST} 16 \quad \mathrm{ST}_{\mathrm{n}+1}=\mathrm{ST} 18 \\
& R L_{n+l}=R L_{n}-R D \\
& \text { IF }\left(\mathrm{RL}_{\mathrm{n}+1} \geqslant \mathrm{CP}\right) \\
& \text { THEN : RL } L_{n+1}=0 \\
& \text { EiLSE: }: R L_{n+1}=R L_{n+1} \\
& \mathrm{ST}_{\mathrm{n}+1}=\mathrm{ST}_{\mathrm{n}+1}
\end{aligned}
$$

IF $\left(\mathrm{ST}_{\mathrm{n}+1}=\mathrm{ST} \cdot 16\right)$

THEN : $\mathrm{ST}_{n+1}=\mathrm{ST} 19 \quad$ ELSE : $\mathrm{ST}_{n+1}=\mathrm{ST} 17$

ST" 19. $A P_{n}=0 R_{n}=0 A L_{n}=0 R_{n}=0 A_{n}^{n}=0 R_{n}=0 P_{n}>0$

$$
\begin{aligned}
& A P_{n+1}=0 R T_{n+1}=0 A L_{n+1}=0 R L_{n+1}=0 A T_{n+1}=0 R T_{n+1}=0 \mathrm{CP}_{n+1}=0 \\
& S T_{n+1}=S T 1
\end{aligned}
$$


ST 20. $A P_{n}>0 R P_{n}=0 A L_{n}>0 R L_{n}=0 A T_{n}>0 R_{n}>0 \mathrm{CP}_{n}>0$

$$
\begin{aligned}
& R P_{n+1}=0 \quad C P_{n+1}>0 \\
& A P_{n+1}=A P_{n}+A D \\
& A L_{\mathrm{n}}+1=A L_{n}+A D \\
& \text { IF }\left(\mathbb{A L}_{n+1} \geqslant \mathrm{CP}_{\mathrm{n}}\right) \\
& \text { THEN : } A L_{n+1}=0 \text { ELSE: } A L_{n+1}=A L_{n+1} \\
& \mathrm{ST}_{\mathrm{n}+1}=\mathrm{ST} 22 \quad \mathrm{ST}_{\mathrm{n}+1}=\mathrm{ST} 20 \\
& A T_{n+1}=A T_{n}-1 \\
& \mathrm{RT}_{\mathrm{n}+1}=\mathrm{RT}_{\mathrm{n}}-1 \\
& \text { IF }\left(\mathrm{RT}_{\mathrm{n}+1}=0\right) \\
& \text { THEN: } R L_{n+1}=100 \\
& \text { ELSE: } R L_{n+1}=0 \\
& \mathrm{ST}_{\mathrm{n}+1}=\mathrm{ST}_{\mathrm{n}+1}
\end{aligned}
$$

IF $\left(\mathrm{ST}_{\mathrm{m}+1}=\mathrm{ST} 22\right)$

THEN : $\mathrm{ST}_{\mathrm{n}+1}=\mathrm{ST} 25 \quad$ ELSE: $: \mathrm{ST}_{\mathrm{n}+1}=\mathrm{ST} 28$

ST 21. $A P_{n}=0 R P_{n}>0 A L_{n}=0 R L_{n}>0 A^{r} T_{n}>0 R_{n}>0 \mathrm{CP}_{n}>0$

$$
\begin{aligned}
& A_{\mathrm{n}+1}=0 \quad \mathrm{CP}_{\mathrm{n}+1}>0 \\
& R P_{n+1}=R P_{n}-R D \\
& \mathrm{RL}_{\mathrm{n}+1}=\mathrm{RL}_{\mathrm{n}}-\mathrm{RD} \\
& \text { IF }\left(R L_{n+1} \leqslant C P_{n}\right) \\
& \text { THEN: } R L_{n+1}=0 \\
& \mathrm{ST}_{\mathrm{n}+1}=\mathrm{ST} 23 \\
& \text { ELSE: } R L_{n+1}=R L_{n+1} \\
& S T_{n+1}=S T 21 \\
& A \mathrm{~T}_{\mathrm{n}+1}=\mathrm{A} \mathrm{T}_{\mathrm{n}}-1 \\
& \text { IF }\left(\mathrm{AT}_{\mathrm{n}+\mathrm{I}}=0\right) \\
& \text { THEN: } \mathbb{A} L_{\mathrm{n}+1}=1 \\
& \text { ELSE: } A L_{n+1}=0 \\
& \mathrm{ST}_{\mathrm{n}+1}=\mathrm{ST}_{\mathrm{n}+1}
\end{aligned}
$$

IF $\left(\mathrm{ST}_{\mathrm{n}+1}=\mathrm{ST} 23\right)$

THEN : $\mathrm{ST}_{\mathrm{n}+1}=\mathrm{ST} 27 \quad$ ELSE: $\mathrm{ST}_{\mathrm{n}+1}=\mathrm{ST} 29$ 
ST 22. $A P_{n}>0 R P_{n}=0 A L_{n}=0 R L_{n}=0 A T_{n}>0 R T_{n}>0 C P_{n}>0$

$$
\begin{aligned}
& R P_{n+1}=0 A L_{n+1}=0 C P_{n+1}>0 \\
& A P_{n+1}=A P_{n}+\overrightarrow{A D} \\
& \operatorname{IF}\left(A P_{n+1} \geqslant C P_{n}\right) \\
& \text { THEN : } A P_{n+1}=0 \\
& \mathrm{ST}_{\mathrm{n}+1}=\mathrm{ST} \| 1 \mathrm{ST} n+1=\mathrm{ST} 22 \\
& \text { THEN : } \mathrm{RL}_{n+1}=100 \\
& \text { ELSE: } \mathrm{RL}_{\mathrm{n}+1}=0 \\
& \mathrm{ST}_{\mathrm{n}+1}=\mathrm{ST}_{\mathrm{n}+1}
\end{aligned}
$$

IF $\left(\mathrm{ST}_{\mathrm{n}+1}=\mathrm{ST} 1 \mathrm{H}\right)$

THEN : $\mathrm{ST}_{n+1}=\mathrm{ST} 13 \quad$ ELSE: $\mathrm{ST}_{\mathrm{n}+1}=\mathrm{ST} 25$

ST 23. $A P_{n}=0 R P_{n}>0 A L_{n}=0 R L_{n}=0 A T_{n}>0 R_{n}^{\prime \prime}>0 C P_{n}>0$

$$
\begin{aligned}
& A P_{n+1}=0 R L_{n+1}=0 C P_{n+1}>0 \\
& \mathrm{RP}_{\mathrm{n}+1}=\mathrm{RP}_{\mathrm{n}}-\mathrm{RD} \\
& \text { IF }\left(\mathrm{RP}_{\mathrm{n}+1} \leqslant \mathrm{CP} \mathrm{P}\right) \\
& \text { THEN : } R P_{n+1}=0 \text { ELSE: } R P_{n+1}=R P_{n+1} \\
& \mathrm{ST}_{\mathrm{n}+1}=\mathrm{S}+11 \quad \mathrm{ST}_{\mathrm{n}+1}=\mathrm{ST} 23 \\
& \text { ELSE: } \mathbb{A L}_{n+1}=0 \\
& \mathrm{ST}_{\mathrm{n}+1}=\mathrm{ST}_{\mathrm{n}+1}
\end{aligned}
$$

IF $\left(\mathrm{ST}_{\mathrm{m}+1}=\mathrm{ST} 11\right)$

THEN : ST $T_{n+1}=S T 12 \quad$ ELSE : $S_{n+1}=$ ST 27

$R \mathrm{~T}_{\mathrm{n}+1}=\mathrm{RT}_{\mathrm{n}}-1$ 
ST 24. $A P_{n}=0 R_{m}>0 A L_{n}=0 R L_{m}>0 A T_{n}=0 R T_{n}>0 C P_{n}>0$

$$
\begin{aligned}
& A P_{n+1}=0 \mathrm{AL}_{\mathrm{n}+1}=0 \mathrm{AT}_{\mathrm{n}+1}=0 \mathrm{CP}_{\mathrm{n}+1}>0 \\
& R P_{n+1}=R P_{n}-\mathrm{RD} \\
& R L_{n+1}=R L_{n}-\mathrm{RD}
\end{aligned}
$$

IF $\left(R_{n+1} \leqslant C P_{n}\right)$

THEN: $\operatorname{RL}_{\mathrm{H}}+1=0$

$S T_{n+1}=S T 32$

$$
\begin{array}{ll}
\text { ELSE }: & R_{n+1}=R L_{n+1} \\
& S_{n+1}=S T 24
\end{array}
$$

$\mathrm{RT}_{\mathrm{n}+1}=\mathrm{RT}_{\mathrm{n}}-1$

ST 25. $\mathrm{AP}_{\mathrm{n}}>0 \mathrm{RP} \mathrm{P}_{\mathrm{n}}=0 \mathrm{AL}_{\mathrm{n}}=0 \mathrm{RL}_{\mathrm{n}}>0 \mathrm{AT}_{\mathrm{n}}>0 \mathrm{RT} \mathrm{T}_{\mathrm{n}}=0 \mathrm{CP} \mathrm{P}_{\mathrm{n}}>0$

$$
\begin{aligned}
& R P_{n+1}=0 A L_{n+1}=0 R T_{n+1}=0 C P_{n+1}>0 \\
& A P_{n+1}=A P_{n}+A D
\end{aligned}
$$

IF $\left(A P_{n+1} \geqslant C P_{n}\right)$

THEN: $\mathrm{AP}_{\mathrm{n}+1}=0$

$S T_{n+1}=S T 13$

ELSE: $\mathbb{A P}_{n+1}=A_{n+1}$

$\mathrm{ST}_{\mathrm{n}+1}=\mathrm{ST} 25$

$R L_{n+1}=R L_{n}-R D$

IF' $\left(\mathrm{RL}_{\mathrm{n}+1} \leqslant \mathrm{CP}_{\mathrm{n}}\right)$

THEN : $R_{n+1}=0$

$$
\text { ELSE: } \begin{aligned}
\mathbb{R L}_{n+1}=\mathrm{RL}_{\mathrm{n}+1} \\
\\
\mathrm{ST}_{\mathrm{n}+1}^{\mathrm{H}}=\mathrm{ST}_{\mathrm{n}+1}
\end{aligned}
$$

IF $\left(\mathrm{ST}_{\mathrm{n}+1}=\mathrm{ST} 13\right)$

THEN : $\mathrm{ST}_{\mathrm{n}+1}=\mathrm{ST} 15 \quad$ ELSE $: \mathrm{ST}_{\mathrm{n}+1}=\mathrm{ST} 31$

$\mathrm{AT}_{n+1}=\mathrm{AT}_{\mathrm{n}}-1$

ST 26. $A P_{n}>0 R P_{n}=0 A_{n}>0 R L_{n}=0 A_{n}>0 R T_{n}=0 \mathrm{CP}_{n}>0$

$\mathrm{RP}_{\mathrm{n}}+1=0 \mathrm{RL}_{\mathrm{n}+1}=0 \mathrm{RT}_{\mathrm{n}+1}=0 \mathrm{CP} \mathrm{P}+1>0$

$A P_{n+1}=A P_{n}+A D$

$A L_{n+1}=A L_{n}=A D$

IF $\left(A L_{n+1} \geqslant C P_{n}\right)$

THEN: $A_{L+1}=0$

ELSE: $A L_{n+1}=A_{2} L_{n+1}$

$\mathrm{ST}_{\mathrm{n}+1}^{n}=\mathrm{ST} 3 \mathrm{l}$

$S \mathrm{I}_{\mathrm{n}+1}=\mathrm{ST} 26$

$A T_{n+1}=A T_{n}-1$ 
ST 27. $A P_{n}=0 R P_{n}>0 A_{n}>0 R L_{n}=0 A T_{n}=0 R T_{n}>0 C P_{n}>0$

$$
\begin{aligned}
& A P_{n+1}=0 R L_{n+1}=0 A T_{n+1}=0 C P_{n+1}>0 \\
& \mathrm{RP}_{\mathrm{n}+1}=\mathrm{RP}_{\mathrm{n}}-\mathrm{RD} \\
& \mathbb{I F}\left(\mathrm{RP}_{\mathrm{n}+1} \leqslant \mathrm{CP} \mathrm{n}\right) \\
& \text { ELSE: } \mathrm{RP}_{\mathrm{n}+1}=\mathrm{RP}_{\mathrm{n}+1} \\
& \mathrm{ST}_{\mathrm{n}+1}=\mathrm{ST} 2 \mathrm{~T}
\end{aligned}
$$

$A L_{n+1}=A L_{\mathbb{R}}+A D$

$\left.\operatorname{IF}\left(A L_{n+1}\right) \mathrm{CP}_{n}\right)$

THEN: $A L_{n+1}=0$

$$
\text { ELSE: } \begin{aligned}
A_{n+1}=A_{n+1} L_{n+1} \\
\\
S T_{n+1}=S T_{n+1}
\end{aligned}
$$

IF $\left(S T_{n+1}=S T 12\right)$

THEN:ST $\mathrm{SH}_{n+1}=\mathrm{ST} 14 \quad$ ELSE : ST $\mathrm{n+1}=\mathrm{ST} 32$

$\mathrm{RT}_{\mathrm{n}+\mathrm{I}}=\mathrm{RT}_{\mathrm{n}}-\mathrm{I}$

ST 28. $A P_{n}>0 R P_{n}=0 A_{L_{n}}>0 R L_{n}>0 A_{n}>0 R_{n}=0 \mathrm{CP}_{n}>0$

$$
\begin{aligned}
& R P_{n+1}=0 R T_{n+1}=0 C P_{n+1}>0 \\
& A P_{n+1}=A P_{n}+A D \\
& A L_{n+1}=A L_{n}+A D \\
& \text { IF }\left(A L_{n+1} \geqslant C P_{n}\right) \\
& \text { THEN: } \mathbb{A L}_{n+1}=0 \quad \text { ELSE: } A L_{n+1}=\mathbb{A L}_{n+1} \\
& \mathrm{ST}_{\mathrm{n}+1}=\mathrm{ST} 25 \quad \mathrm{ST}_{\mathrm{n}+1}=\mathrm{ST} 28 \\
& \text { ELSE: } \quad \mathrm{RL}_{\mathrm{n}+1}=\mathrm{RL}_{\mathrm{n}+1} \\
& S T_{n+1}=S T_{n+1}
\end{aligned}
$$

IF (ST $\mathrm{M}+\mathrm{I}=\mathrm{ST} 25)$

THEN : $\mathrm{ST}_{n+1}=\mathrm{ST} 31 \quad$ ELSE : ST $\mathrm{n+1}=\mathrm{ST} 26$

$$
A T_{n+1}=A T_{n}-1
$$


ST 29. $A P_{n}=0 R P_{n}>0 A L_{n}>0 R L_{n}>0 A T_{n}=0 R T_{n}>0 \mathrm{CP}_{n}>0$

$A P_{n+1}=0 A T_{n+1}=0 A P_{n+1}>0$

$R P_{n+1}=R P_{n}-R D$

$A L_{n+1}=A L_{n}+A D$

IF $\left(A L_{n+1} \geqslant C P_{n}\right)$

THEN: $\mathbb{A} L_{n+1}=0$

$\mathrm{ST}_{\mathrm{n}+1}=\mathrm{ST} 24$

ELSE: $A L_{n+1}=A L_{n+1}$

$\mathrm{ST}_{\mathrm{n}+1}=\mathrm{ST} 29$

$R L_{n+1}=R L_{n}-R D$

IF $\left(\mathrm{RL}_{\mathrm{n}+1} \leqslant \mathrm{CP} \mathrm{P}_{\mathrm{n}}\right)$

THEN: $R L_{n+1}=0$

ELSE: $R L_{n+1}=R L_{n+1}$

$S \mathrm{~T}_{n+1}=\mathrm{ST}_{\mathrm{n}+1}$

IF $\left(\mathrm{ST}_{\mathrm{n}+1}=\mathrm{ST} 24\right)$

THEN : $\mathrm{ST}_{\mathrm{n}+1}=\mathrm{ST} 32 \quad$ ELSE $: \mathrm{ST}_{\mathrm{n}+1}=\mathrm{ST} 27$

$\mathrm{RT}_{\mathrm{n}+1}=\mathrm{RT}_{\mathrm{n}}-1$

ST 30. $A P_{n}>0 R_{n}>0 A L_{n}>0 R L_{n}>0 A_{n}^{\prime}>0 R_{n}>C P_{n}>0$

$$
\begin{aligned}
& \mathrm{CP}_{n+1}>0 \\
& A P_{n+1}=A P_{n}+A D \\
& R P_{n+1}=R P_{n}-R D \\
& A L_{n+1}=A L_{n}+A D \\
& \text { IF }\left(A L_{n+1} \geqslant C P_{n}\right) \\
& T H E N: \begin{array}{ll}
A L_{n+1}=0 \\
S T_{n+1}=S T 34
\end{array} \\
& R L_{n+1}=R L_{n}-R D \\
& \text { IF }\left(R L_{n+1} \leqslant C P_{n}\right) \\
& T H E N: R L_{n+1}=0
\end{aligned}
$$

IF $\left(\mathrm{ST}_{\mathrm{n}+1}=\mathrm{ST}^{\mathrm{T}}\right.$ ? 34$)$

THEN : $\mathrm{ST}_{\mathrm{n}+1}=\mathrm{ST} 33 \quad$ ELSE : $S \mathrm{~T}_{\mathrm{n}+1}=\mathrm{ST} 35$

$$
\begin{aligned}
& A T_{n+1}=A T_{n}-1 \\
& R T_{n+1}=R T_{n}-1
\end{aligned}
$$


ST 3\%. $A P_{n}>0 \mathrm{RP}_{\mathrm{n}}=0 \mathrm{AL}_{\mathrm{rn}}=0 \mathrm{RL}_{\mathrm{n}}=0 \mathrm{AT}_{\mathrm{n}}>0 \mathrm{RT} \mathrm{n}=0 \mathrm{CP} \mathrm{n}>0$

$$
\begin{aligned}
& \mathrm{RP}_{n+1}=0 \mathrm{AL}_{n+1}=0 \mathrm{RL} L_{n+1}=0 \mathrm{RT} \\
& A P_{n+1}=\mathrm{AP}_{\mathrm{n}}+\mathrm{AD}
\end{aligned}
$$

IF $\left(A_{n+1} P_{n+1} \geqslant \mathrm{CP}_{n}\right)$

THEN: $\mathrm{AP}_{\mathrm{n}+\mathrm{l}}=0$

$$
\begin{aligned}
& \mathrm{ST}_{\mathrm{n}+1}=\mathrm{ST} 15 \\
& \mathrm{CP}_{\mathrm{n}+1}=\mathrm{CP}_{\mathrm{n}}
\end{aligned}
$$

$$
\begin{aligned}
\text { ELSE }: & A P_{n+1}=A P_{n+1} \\
& S T_{n+1}=S T 2 \\
& C P_{n+1}=0
\end{aligned}
$$

$A T_{n+1}=A T_{n}-1$

ST 32. $A P_{n}=0 R P_{n}>0 A L_{n}=0 R L_{n}=0 A T_{n}=0 R T_{n}>0 \mathrm{CP}_{n}>0$

$$
\begin{aligned}
& A P_{n+1}=0 A L_{n+1}=0 R L_{n+1}=0 A T_{n+1}=0 \\
& R P_{n+1}=R P_{n}-R D \\
& \text { IF }\left(R P_{n+1} \leqslant C P_{n}\right) \\
& \text { THEN: } R P_{n+1}=0 \\
& S T_{n+1}=S T 1.4 \\
& C P_{n+1}=C P_{n} \\
& \text { ELSE: } R P_{n+1}=R P_{n+1} \\
& \mathrm{ST}_{\mathrm{n}}+1=\mathrm{ST} 6 \\
& \mathrm{CP}_{n+1}=0
\end{aligned}
$$

ST 33

$A P_{n}>0 R P_{n}>0 A L_{n}=0 R L_{n}=0 A T_{n}>0 R_{n}>0 \mathrm{CP}_{n}>0$

$$
\begin{aligned}
& A L_{n+1}=0 R L_{n+1}=0 C P_{n+1}>0 \\
& A P_{n+1}=A P_{n}+A D \\
& I F\left(A P_{n+1} \geqslant C P_{n}\right) \\
& \text { THEN: } A P_{n+1}=0 \quad \text { ELSE: } A P_{n+1}=A P_{n+1} \\
& S T_{n+1}=S T 23 \quad S T_{n+1}=S T 33 \\
& \mathrm{RP}_{\mathrm{n}+1}=\mathrm{RP}_{\mathrm{n}}-\mathrm{RD} \\
& \text { IF }\left(\mathrm{RP}_{\mathrm{n}+1} \leqslant \mathrm{CP} \mathrm{P}_{\mathrm{n}}\right) \\
& \text { THEN: } \mathrm{RP}_{\mathrm{n}+1}=0 \\
& \text { ELSE: } R P_{n+1}=R P_{n+1} \\
& \mathrm{ST}_{\mathrm{n}+\mathrm{l}}=\mathrm{ST}_{\mathrm{n}+1}
\end{aligned}
$$

$\mathrm{IF}\left(\mathrm{ST}_{\mathrm{n}+1}=\mathrm{ST} 23\right)$

THEN : $\mathrm{ST}_{\mathrm{n}+1}=\mathrm{ST} 11 \quad$ ELSE : $\mathrm{ST}_{\mathrm{n}+1}=\mathrm{ST} 22$

$$
\begin{aligned}
& A T_{n+1}=A T_{n-1} \\
& \mathrm{RT}_{n+1}=\mathrm{RT}_{\mathrm{n}}-1
\end{aligned}
$$


ST 34. $A P_{n}>0 R P_{n}>0 A L_{n}=0 R L_{n}>0 A T_{n}>0 R T_{n}>0 \mathrm{CP}_{n}>0$

$$
\begin{aligned}
& A L_{n+1}=0 C P_{n+1}>0 \\
& A P_{n+1}=A P_{n}+A D \\
& \mathbb{I F}\left(A P_{n+1} \geqslant C P_{n}\right)
\end{aligned}
$$

THEN: $A P_{n+1}=0$

$$
\mathrm{ST}_{\mathrm{n}+1}=\mathrm{ST} 2 \mathrm{I}
$$

$$
\text { ELSE: } \begin{aligned}
A P_{n+1}=A P_{n+1} \\
S T_{n+1}=S T 34
\end{aligned}
$$

$R P_{n+1}=R P_{n}-R D$

$R L_{n+1}=R L_{n}-R D$

$\operatorname{IF}\left(\mathrm{RL}_{\mathrm{n}+1} \leqslant \mathrm{CP}\right)$

THEN : $R L_{n+1}=0$

$$
\text { ELSE: } \begin{aligned}
\mathrm{RL}_{\mathrm{n}+1}=\mathrm{RL}_{\mathrm{n}}+1 \\
\mathrm{ST}_{\mathrm{n}+1}=\mathrm{ST}_{\mathrm{n}+1}
\end{aligned}
$$

IF $\left(\mathrm{ST}_{\mathrm{n}+1}=\mathrm{ST} 21\right)$

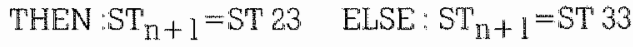

$$
\begin{aligned}
& A T_{n+1}=A_{n}-1 \\
& R T_{n+1}=\mathrm{RT}_{n}-1
\end{aligned}
$$

ST 35. $A P_{n}>0 R P_{n}>0 A_{n}>0 R L_{n}=0 A T_{n}>0 R T_{n}>0 \mathrm{CP}_{n}>0$

$$
\begin{aligned}
& R L_{n+1}=0 C P_{n+1}>0 \\
& A P_{n+1}=A P_{n}+A D \\
& R P_{n+1}=R P_{n}-R D \\
& \mathbb{L F}\left(R P_{n+1} \leqslant C P_{n}\right) \\
& \text { THEN : } R P_{n+1}=0 \text { ELSE: } R P_{n+1}=R P_{n+1} \\
& \mathrm{ST}_{\mathrm{n}+1}=\mathrm{ST} 20 \quad \mathrm{ST}_{\mathrm{n}+1}=\mathrm{ST} 35 \\
& A L_{n+1}=A L_{n}+A D \\
& \text { IF }\left(A L_{n+1} \geqslant C P_{n}\right) \\
& \text { THEN: } A L_{n+1}=0 \\
& \text { ELSE: } \quad \mathrm{AL}_{\mathrm{n}+1}=A L_{n+1} \\
& \mathrm{ST}_{\mathrm{n}+1}=\mathrm{ST}_{\mathrm{n}+1}
\end{aligned}
$$

IF' $\left(\mathrm{ST}_{\mathrm{n}+1}=\mathrm{ST} 20\right)$

THEN : $\mathrm{ST}_{\mathrm{n}+1}=\mathrm{ST} 22 \quad$ ELSE: $: \mathrm{ST}_{\mathrm{n}+1}=\mathrm{ST} 33$

$$
\begin{aligned}
& \mathrm{AT}_{\mathrm{n}+1}=\mathrm{AT}_{\mathrm{n}}-1 \\
& \mathrm{RT}_{\mathrm{n}+1}=\mathrm{RT}_{\mathrm{n}}-1
\end{aligned}
$$




\section{Chapter 7}

\section{Appendix II: The introduction of a new impulse}

A DESCRIPTION IN THE 35 DIFFERENT STATES

ST 1. $A P_{n}=0 R P_{n}=0 A L_{n}=0 R L_{n}=0 A T_{n}=0 R T_{n}=0 \mathrm{CP}_{n}=0$

ANTEROGRADE

$A P_{n+1}=1 R P_{n+1}=0 A L_{n+1}=0 R_{n+1}=0 A T_{n+1}=A R P R T_{n+1}=0 C P_{n+1}=0$ $\mathrm{ST}_{\mathrm{n}+1}=\mathrm{ST} 2$

RETROGRADE

$A P_{n+1}=0 R P_{n+1}=100 A L_{n+1}=0 R L_{n+1}=0 A T_{n+1}=0 R T_{n+1}=R R P P_{n+1}=0$ $\mathrm{ST}_{\mathrm{n}+1}=\mathrm{ST} 6$

ST. 2. $A P_{n}>0 R P_{n+1}=0 A L_{n}=0 R L_{n}=0 A T_{n}>0 R T_{n}=0 C_{n}=0$

ANTEROGRADE REFRACTORY

$A P_{n+1}>0 R P_{n+1}=0 A L_{n+1}=0 R L_{n+1}=0 A T_{n+1}>0 R T_{n+1}=0 C P_{n+1}=0$

RETROGRADE

$A P_{n+1}>0 R P_{n+1}=100 A L_{n+1}=0 R L_{n+1}=0 A T_{n+1}>0 R T_{n+1}=R R P C P_{n+1}=0$ $\mathrm{ST} \cdot \mathrm{n}+\mathrm{STT} 10$

ST 3. $A P_{n}=0 R P_{n}=0 A L_{n}=0 R L_{n}=0 A T_{n}>0 R T_{n}=0 C_{n}=0$

ANTEROGRADE REFRACTORY

$A P_{n+1}=0 R P_{n+1}=0 A L_{n+1}=0 R L_{n+1}=0 A T_{n+1}>0 R T_{n+1}=0 C P_{n+1}=0$ RETROGRADE REFRACTORY

$A P_{n+1}=0 R P_{n+1}=0 A L_{n+1}=0 R L_{n+1}=0 A T_{n+1}>0 R T_{n+1}=0 C P_{n+1}=0$ 
ST 4. $A P_{n}=0 R P_{n}=0 A L_{n}>0 \mathrm{RL}_{n}=0 A T_{n}=0 R T_{n}=0 \mathrm{CP}_{n}=0$

ANTEROGRADE

$R P_{n+1}=0 A L_{n+1}>0 R L_{n+1}=0 R T_{n+1}=0 C P_{n+1}=0$

IF $\left(\mathbb{A} L_{n+1}>(1+\mathbb{A D})\right)$

THEN: $A P_{n+1}=1$

ELSE: $A P_{n+1}=0$

$$
\begin{array}{ll}
\mathrm{AT}_{\mathrm{n}+1}=\mathrm{ARP} & \mathrm{AT}_{\mathrm{n}+1}=0 \\
\mathrm{ST}_{\mathrm{n}+1}=\mathrm{ST} 5 & \mathrm{ST}_{\mathrm{n}+1}=\mathrm{ST} 4
\end{array}
$$

RETROGRADE REFRACTORY

$A P_{n+1}=0 R P_{n+1}=0 A L_{n+1}>0 R L_{n+1}=0 A T_{n+1}=0 R T_{n+1}=0 C P_{n+1}=0$

ST 5. $A P_{n}>0 R P_{n}=0 A L_{n}>0 R L_{n}=0 A T_{n}>0 R T_{n}=0 \mathrm{CP}_{n}=0$

ANTEROGRADE REFRACTORY

$A P_{n+1}>0 \mathrm{RP}_{\mathrm{n}+1}=0 A \mathrm{~L}_{\mathrm{n}+1}>0 \mathrm{RL}_{\mathrm{n}+1}=0 \mathrm{AT}_{\mathrm{n}+1}>0 \mathrm{RT}_{\mathrm{n}+1}=0 \mathrm{CP}_{\mathrm{n}+1}=0$

RETROGRADE REFRACTORY

$A P_{n+1}>0 R P_{n+1}=0 A L_{n+1}>0 \mathrm{RL}_{n+1}=0 \mathrm{AT}_{\mathrm{n}+1}>0 \mathrm{RT}_{\mathrm{n}+1}=0 \mathrm{CP}_{\mathrm{n}+1}=0$

ST 6. $A P_{n}=0 R P_{n}>0 A L_{n}=0 R L_{n}=0 A T_{n}=0 R T_{n}>0 \mathrm{CP}_{n}=0$

ANTEROGRADE

$A P_{n+1}=1 R P_{n+1}>0 A L_{n+1}=0 R L_{n+1}=0 A T_{n+1}=A R P R T_{n+1}>0 C P_{n+1}=0$

$\mathrm{ST}_{\mathrm{n}+1}=\mathrm{ST} 10$

RETROGRADE REFRACTORY

$A P_{n+1}=0 R P_{n+1}>0 A L_{n+1}=0 R L_{n+1}=0 A T_{n+1}=0 R T_{n+1}>0 \mathrm{CP}_{n+1}=0$

ST 7. $A P_{n}=0 R P_{n}=0 A L_{n}=0 R L_{n}=0 A T_{n}=0 R T_{n}>0 \mathrm{CP}_{n}=0$

ANTEROGRADE REFRACTORY

$A P_{n+1}=0 R P_{n+1}=0 A L_{n+1}=0 R L_{n+1}=0 A T_{n+1}=0 R T_{n+1}>0 C P_{n+1}=0$

RETROGRADE REFRACTORY

$A P_{n+1}=0 R P_{n+1}=0 A L_{n+1}=0 R L_{n+1}=0 A T_{n+1}=0 R T_{n+1}>0 C P_{n+1}=0$ 
ST 8. $A P_{n}=0 R P_{n}=0 A L_{n}=0 R L_{n}>0 A T_{n}=0 R T_{n}=0 \mathrm{CP}_{n}=0$

ANTEROGRADE REFRACTORY

$A P_{n+1}=0 R P_{n+1}=0 A L_{n+1}=0 R L_{n+1}>0 A T_{n+1}=0 R T_{n+1}=0 C P_{n+1}=0$

RETROGRADE

$A P_{n+1}=0 A L_{n+1}=0 R L_{n+1}>0 A T_{n+1}=0 C P_{n+1}=0$

$\operatorname{IF}\left(\mathrm{RL}_{\mathrm{\Omega}}+1<(100-\mathrm{RD})\right)$

THEN : $R P_{n+1}=100 \quad$ ELSE : $R P_{n+1}=0$

$\mathrm{RT}_{\mathrm{n}+1}=\mathrm{RRP} \quad \mathrm{RT}_{\mathrm{n}+1}=0$

$\mathrm{ST}_{\mathrm{n}+1}=\mathrm{ST} 9 \quad \mathrm{ST}_{\mathrm{n}+1}=\mathrm{ST} 8$

ST 9. $A P_{n}=0 R P_{n}>0 A L_{n}=0 R L_{n}>0 A T_{n}=0 R T_{n}>0 C_{n}=0$

ANTEROGRADE REFRACTORY

$A P_{n+1}=0 R P_{n+1}>0 A L_{n+1}=0 R L_{n+1}>0 A T_{n+1}=0 R T_{n+1}>0 C P_{n+1}=0$

RETROGRADE REFRACTORY

$A P_{n+1}=0 R_{n+1}>0 A L_{n+1}=0 \mathrm{RL}_{n+1}>0 \mathrm{AT}_{\mathrm{n}+1}=0 \mathrm{RT}_{\mathrm{n}+1}>0 \mathrm{CP}_{\mathrm{n}+1}=0$

ST 10. $A P_{n}>0 R P_{n}>0 A L_{n}=0 R L_{n}=0 A T_{n}>0 R T_{n}>0 C_{n}=0$

ANTEROGRADE REFRACTORY

$A P_{n+1}>0 R P_{n+1}>0 A L_{n+1}=0 R L_{n+1}=0 A T_{n+1}>0 R T_{n+1}>0 \mathrm{CP}_{n+1}=0$

RETROGRADE REFRACTORY

$A P_{n+1}>0 R P_{n+1}>0 \mathrm{AL}_{n+1}=0 R L_{n+1}=0 A T_{n+1}>0 \mathrm{RT}_{n+1}>0 \mathrm{CP}_{n+1}=0$

ST 11. $A P_{n}=0 R P_{n}=0 A L_{n}=0 R L_{n}=0 A T_{n}>0 R T_{n}>0 A P_{n}>0$

ANTEROGRADE REFRACTORY

$A P_{n+1}=0 R P_{n+1}=0 A L_{n+1}=0 R_{n+1}=0 A T_{n+1}>0 R_{n+1}>0 \mathrm{CP}_{n+1}>0$

RETROGRADE REFRACTORY

$A P_{n+1}=0 R P_{n+1}=0 A L_{n+1}=0 R L_{n+1}=0 A T_{n+1}>0 R_{n+1}>0 \mathrm{CP}_{n+1}>0$ 
ST 12. $A P_{n}=0 R P_{n}=0 A L_{n}>0 R L_{n}=0 A T_{n}=0 R T_{n}>0 \mathrm{CP}_{n}>0$

ANTEROGRADE

$R P_{n+1}=0 \AA L_{n+1}>0 R L_{n+1}=0 R T_{n+1}>0 C P_{n+1}>0$

$\operatorname{IF}\left(\mathrm{AL}_{\mathrm{n}+1}>(1+\AA \mathrm{AD})\right)$

THEN : $A P_{n+1}=1$

$A T_{n+1}=A R P$

ELSE : $A P_{n+1}=0$

$\mathrm{ST}_{\mathrm{n}+1}=\mathrm{ST} 20$

$A T_{n+1}=0$

$\mathrm{ST}_{\mathrm{n}+1}=\mathrm{ST} 12$

RETROGRADE REFRACTORY

$A P_{n+1}=0 R P_{n+1}=0 A L_{n+1}>0 \mathrm{RL}_{n+1}=0 A T_{n+1}=0 R T_{n+1}>0 \mathrm{CP}_{n+1}>0$

ST 13. $A P_{n}=0 R P_{n}=0 A L_{n}=0 R L_{n}>0 A T_{n}>0 R T_{n}=0 C P_{n}>0$

ANTEROGRADE REFRACTORY

$A P_{n+1}=0 R P_{n+1}=0 A L_{n+1}=0 R L_{n+1}>0 A T_{n+1}>0 R T_{n+1}=0 C P_{n+1}>0$

RETROGRADE

$A P_{n+1}=0 A L_{n+1}=0 R L_{n+1}>0 A T_{n+1}>0 \mathrm{CP}_{n+1}>0$

IF $\left(R L_{n+1}<(100-R D)\right)$

THEN : RP $n+1=100$

$$
\begin{array}{ll}
\mathrm{RT}_{\mathrm{n}+1}=\mathrm{RRP} & \mathrm{RT}_{\mathrm{n}+1}=0 \\
\mathrm{ST}_{\mathrm{n}+1}=\mathrm{ST} 21 & \mathrm{ST}_{\mathrm{n}+1}=\mathrm{ST} 13
\end{array}
$$

ELSE: $R P_{n+1}=0$

$\operatorname{ST}$ 14. $A P_{n}=0 R P_{n}=0 A L_{n}=0 R L_{n}=0 A T_{n}=0 R T_{n}>0 \mathrm{CP}_{n}>0$

ANTEROGRADE

$A P_{n+1}=1 R P_{n+1}=0 A L_{n+1}=0 R L_{n+1}=0 A T_{n+1}=A R P R T_{n+1}>0 C P_{n+1}>0$ $\mathrm{ST}_{\mathrm{n}+1}=\mathrm{ST} 22$

RETROGRADE REFRACTORY

$A P_{n+1}=0 R P_{n+1}=0 A L_{n+1}=0 R L_{n+1}=0 A T_{n+1}=0 R T_{n+1}>0 C P_{n+1}>0$ 
ST 15. $A P_{n}=0 R P_{n}=0 A L_{n}=0 R L_{n}=0 A T_{n}>0 R T_{n}=0 \quad P_{n}>0$

ANTEROGRADE REFRACTORY

$A P_{n+1}=0 R P_{n+1}=0 A L_{n+1}=0 R L_{n+1}=0 A T_{n+1}>0 R T_{n+1}=0 \mathrm{CP}_{n+1}>0$

RETROGRADE

$A P_{n+1}=0 R P_{n+1}=100 A L_{n+1}=0 R L_{n+1}=0 A T_{n+1}>0 R T_{n+1}=R R P C P_{n+1}>0$ $\mathrm{ST}_{\mathrm{n}+1}=\mathrm{ST} 23$

ST 16. $A P_{n}=0 R P_{n}=0 A L_{n}=0 R L_{n}>0 A T_{n}=0 R T_{n}^{n}=0 \mathrm{CP}_{n}>0$

ANTEROGRADE

$A P_{n+1}=1 R P_{n+1}=0 A L_{n+1}=0 R L_{n+1}>0 A T_{n+1}=A R P R_{n+1}=0 C P_{n+1}>0$ $\mathrm{ST}_{\mathrm{n}+\mathrm{l}}=\mathrm{ST} 25$

RETROGRADE

$A P_{n+1}=0 A L_{n+1}=0 R L_{n+1}>0 A T_{n+1}=0 \mathrm{CP}_{n+1}>0$

IF $\left(R L_{n+1}<(100-R D)\right)$

THEN : $R P_{n+1}=100 \quad$ ELSE : $R P_{n+1}=0$

$\mathrm{RT}_{\mathrm{n}+1}=\mathrm{RRP} \quad \mathrm{RT}_{\mathrm{n}+1}=0$

$\mathrm{ST}_{\mathrm{n}+1}=\mathrm{ST} 24 \quad \mathrm{ST}_{\mathrm{n}+1}=\mathrm{ST} 16$

ST 17. $A P_{n}=0 R P_{n}=0 A L_{n}>0 R L_{n}=0 A T_{n}=0 R_{n}=0 \mathrm{CP}_{n}>0$

ANTEROGRADE

$R P_{n+1}=0 A L_{n+1}>0 R L_{n+1}=0 R T_{n+1}=0 C P_{n+1}>0$

$\operatorname{IF}\left(A L_{n+1}>(1+A D)\right)$

THEN: $A P_{n+1}=1$

$\mathrm{AT}_{\mathrm{n}+1}=\mathrm{ARP}$

ELSE: $A P_{n+1}=0$

$\mathrm{ST}_{\mathrm{n}+1}=\mathrm{ST} 26$

$\mathrm{AT}_{\mathrm{n}+1}=0$

$\mathrm{ST}_{\mathrm{n}+1}=\mathrm{ST} 17$

RETROGRADE

$A P_{n+1}=0 R P_{n+1}=100 \AA L_{n+1}>0 R L_{n+1}=0 A T_{n+1}=0 R T_{n+1}=R R P C P_{n+1}>0$

$S T_{n+1}=S T 2 T$ 
ST 18. $A P_{n}=0 R P_{n}=0 A L_{n}>0 R L_{n}>0 A T_{n}=0 R T_{n}=0 C P_{n}>0$

ANTEROGRADE

$R P_{n+1}=0 A L_{n+1}>0 R L_{n+1}>0 \mathrm{RT}_{n+1}=0 \mathrm{CP}_{\mathrm{n}+1}>0$

$\operatorname{IF}\left(A L_{n+1}>(1+A D)\right)$

THEN: $A P_{n+1}=1$

$\mathrm{AT}_{\mathrm{n}+1}=\mathrm{ARP}$

ElsSE: $A P_{n+1}=0$

$\mathrm{ST}_{\mathrm{n}+1}=\mathrm{ST} 28$

$A T_{n+1}=0$

$\mathrm{ST}_{n+1}=\mathrm{ST} 18$

RETROGRADE

$A P_{n+1}=0 A L_{n+1}>0 R L_{n+1}>0 A T_{n+1}=0 R T_{n+1}=0 C P_{n+1}>0$

$\mathbb{I F}\left(R L_{n+1}<(100-R D)\right)$

THEN: $R P_{n+1}=100$

$$
\begin{aligned}
& R T_{n+1}=R R P \\
& S T_{n+1}=S T 29
\end{aligned}
$$

ELSE: $R P_{n+1}=0$

$\mathrm{RT}_{\mathrm{n}+1}=0$

$\mathrm{ST}_{\mathrm{n}+1}=\mathrm{ST} 18$

ST' 19. $A P_{n}=0 R P_{n}=0 A L_{n}=0 R L_{n}=0 A T_{n}=0 R T_{n}=0 A P_{n}>0$

\section{ANTEROGRADE}

$A P_{n+1}=1 R P_{n+1}=0 A L_{n+1}=0 R L_{n+1}=0 A T_{n+1}=A R P R T_{n+1}=0 C P_{n+1}>0$ $\mathrm{ST}_{\mathrm{n}+1}=\mathrm{ST} 3 \mathrm{H}$

RETROGRADE

$A P_{n+1}=0 R P_{n+1}=100 A L_{n+1}=0 R L_{n+1}=0 A T_{n+1}=0 R T_{n+1}=R R P C P_{n+1}>0$ $\mathrm{ST}_{\mathrm{n}+1}=\mathrm{ST} 32$

ST 20. $A P_{n}>0 R P_{n}=0 A L_{n}>0 R L_{n}=0 A T_{n}>0 R T_{n}>0 C P_{n}>0$

ANTEROGRADE REFRACTORY

$A P_{n+1}>0 R P_{n+1}=0 A L_{n+1}>0 R L_{n+1}=0 A T_{n+1}>0 R T_{n+1}>0 C P_{n+1}>0$

RETROGRADE REFRACTORY

$A P_{n+1}>0 R P_{n+1}=0 A L_{n+1}>0 R L_{n+1}=0 A T_{n+1}>0 R T_{n+1}>0 C P_{n+1}>0$ 
ST 21. $A P_{n}=0 R F_{n}>0 A L_{n}=0 R L_{n}>0 A T_{n}>0 R T_{n}>0 \mathrm{CP}_{n}>0$

ANTEROGRADE REFRACTORY

$A P_{n+1}=0 R P_{n+1}>0 A L_{n+1}=0 R L_{n+1}>0 \tilde{A T}_{n+1}>0 R T_{n+1}>0 \mathrm{CP}_{n+1}>0$

RETROGRADE REFRACTORY

$A P_{n+1}=0 R P_{n+1}>0 A L_{n+1}=0 R L_{n+1}>0 A T_{n+1}>0 R T_{n+1}>0 C P_{n+1}>0$

ST 22. $A P_{n}>0 R P_{n}=0 A L_{n}=0 R L_{n}=0 A T_{n}>0 R T_{n}>0 C P_{n}>0$

ANTEROGRADE REFRACTORY

$A P_{n+1}>0 R P_{n+1}=0 A L_{n+1}=0 R L_{n+1}=0 A T_{n+1}>0 R n_{n+1}>0 C P_{n+1}>0$

RETROGRADE REFRACTORY

$A P_{n+1}>0 R P_{n+1}=0 A L_{n+1}=0 R L_{n+1}=0 A T_{n+1}>0 R T_{n+1}>0 \mathrm{CP}_{n+1}>0$

ST. 23. $A P_{n}=0 R_{n}>0 \mathrm{AL}_{n}=0 \mathrm{RL}_{\mathrm{n}}=0 \mathrm{AT}_{\mathrm{n}}>0 \mathrm{RT}_{\mathrm{n}}>0 \mathrm{CP}_{\mathrm{n}}>0$

ANTEROGRADE REFRACTORY

$A P_{n+1}=0 R P_{n+1}>0 A L_{n+1}=0 R L_{n+1}=0 A T_{n+1}>0 R T_{n+1}>0 C P_{n+1}>0$

RETROGRADE REFRACTORY

$A P_{n+1}=0 R P_{n+1}>0 A L_{n+1}=0 R L_{n+1}=0 A T_{n+1}>0 R T_{n+1}>0 C P_{n+1}>0$

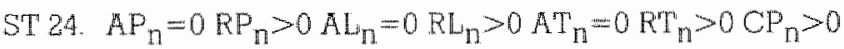

ANTEROGRADE

$A P_{n+1}=1 R P_{n+1}>0 A L_{n+1}=0 \mathrm{RL}_{n+1}>0 \mathrm{AT}_{n+1}=\mathrm{ARPRT}_{n+1}>0 \mathrm{CP}_{n+1}>0$ $\mathrm{ST}_{\mathrm{n}+1}=\mathrm{ST} 34$

RETROGRADE REFRACTORY

$A P_{n+1}=0 R P_{n+1}>0 A L_{n+1}=0 R L_{n+1}>0 A T_{n+1}=0 R T_{n+1}>0 C P_{n+1}>0$ 
ST 29. $A P_{n}>0 R P_{n}=0 A L_{n}=0 R L_{n}>0 A T_{n}>0 R T_{n}=0 C P_{n}>0$

ANTEROGRADELY REFRACTORY

$A P_{n+1}>0 R P_{n+1}=0 A L_{n+1}=0 R L_{n+1}>0 A T_{n+1}>0 R T_{n+1}=0 C P_{n+1}>0$

RETROGRADE

$A P_{n+1}>0 A L_{n+1}=0 R L_{n+1}>0 A T_{n+1}^{n}>0 C P_{n+1}>0$

$\mathbb{I F}\left(R L_{n+1}<(100-R D)\right)$

THEN : $R P_{n+1}=1.00$ ELSE: $\operatorname{RP}_{n+1}=0$

$\mathrm{RT}_{\mathrm{n}+1}=\mathrm{RRP} \quad \mathrm{RT}_{\mathrm{n}+1}=0$

$\mathrm{ST}_{\mathrm{n}+1}=\mathrm{ST} 34 \quad \mathrm{ST}_{\mathrm{n}+1}=\mathrm{ST} 25$

ST26. $A P_{n}>0 R P_{n}=0 A L_{n}>0 R L_{n}=0 A T_{n}>0 R T_{n}=0 C P_{n}>0$

ANTEROGRADE REFRACTORY

$A P_{n+1}>0 R P_{n+1}=0 A L_{n+1}>0 R L_{n+1}=0 A T_{n+1}>0 R T_{n+1}=0 C P_{n+1}>0$

RETROGRADE

$A P_{n+1}>0 R P_{n+1}=100 A L_{n+1}>0 R L_{n+1}=0 A T_{n+1}>0 R T_{n+1}=R R P C P_{n+1}>0$ $\mathrm{ST}_{\mathrm{n}+1}=\mathrm{ST} 35$

ST 27. $A P_{n}=0 R P_{n}>0 A L_{n}>0 R L_{n}=0 A T_{n}=0 R m_{n}>0 \mathrm{CP}_{n}>0$

ANTEROGRADE

$R P_{n+1}>0 A L_{n+1}>0 R L_{n+1}=0 R T_{n+1}>0 C P_{n+1}>0$

$\operatorname{IF}\left(A L_{n+1}>(1+A D)\right)$

THEN: $A P_{n+1}=1$

ELSE: $\mathbb{A P}_{n+1}=0$

$\mathrm{AT}_{\mathrm{n}+1}=\mathrm{ARP}$

$\mathrm{AT}_{\mathrm{n}+1}=0$

$\mathrm{ST}_{\mathrm{n}+1}=\mathrm{ST} 35$

$\mathrm{ST}_{\mathrm{n}+1}=\mathrm{ST} 2 \mathrm{~T}$

RETROGRADE REFRACTORY

$A P_{n+1}=0 R P_{n+1}>0 A L_{n+1}>0 R L_{n+1}=0 A T_{n+1}=0 R T_{n+1}>0 C P_{n+1}>0$ 
ST 28. $A P_{n}>0 R P_{n}=0 A L_{n}>0 R L_{n}>0 A T_{n}>0 R T_{n}=0 C P_{n}>0$

ANTEROGRADE REFRACTORY

$A P_{n+1}>0 R P_{n+1}=0 A L_{n+1}>0 R L_{n+1}>0 A T_{n+1}>0 R T_{n+1}=0 C P_{n+1}>0$

RETROGRADE

$A P_{n+1}>0 A L_{n+1}>0 R L_{n+1}>0 A T_{n+1}>0 C P_{n+1}>0$

IF $\left(\mathrm{RL}_{n+1}<(100-\mathrm{RD})\right)$

THEN : $R P_{n+1}=100$

$\mathrm{RT}_{\mathrm{n}+1}=\mathrm{RRP}$

ELSE: $R P_{n+1}=0$

$S T_{n+1}=S T 30$

$\mathrm{RT}_{\mathrm{n}+1}=0$

$\mathrm{ST}^{\mathrm{T}} \mathrm{n}+1=\mathrm{ST}^{\prime} 28$

ST 29. $A P_{n}=0 R P_{n}>0 A L_{n}>0 R L_{n}>0 A T_{n}=0 R T_{n}>0 \quad C P_{n}>0$

ANTEROGRADE

$R P_{n+1}>0 A L_{n+1}>0 R L_{n+1}>0 R T_{n+1}=0 C P_{n+1}>0$

IF $\left(A L_{n+1}>(1+A D)\right.$

THEN : $A P_{n+1}=1$

$\mathrm{AP}_{\mathrm{n}+1}=\mathrm{ARP}$

ELSE: $A P_{n+1}=0$

$\mathrm{ST}_{\mathrm{n}+1}=\mathrm{ST} 30$

$A T_{n+1}^{n}=0$

$\mathrm{ST}_{\mathrm{n}+1}=\mathrm{ST} 29$

RETROGRADELY REFRACTORY

$A P_{n+1}=0 R P_{n+1}>0 A L_{n+1}>0 R L_{n+1}>0 A T_{n+1}=0 R T_{n+1}>0 \mathrm{CP}_{n+1}>0$

ST 30. $A P_{n}>0 R P_{n}>0 A L_{n}>0 R L_{n}>0 A T_{n}>0 R_{n} T_{n}>0 \mathrm{CP}_{n}>0$

ANTEROGRADE REFRACTORY

$A P_{n+1}>0 R P_{n+1}>0 A L_{n+1}>0 R L_{n+1}>0 A T_{n+1}>0 \mathrm{RT}_{n+1}>0 \mathrm{CP}_{n+1}>0$

RETROGRADE REFRACTORY

$A P_{n+1}>0 R P_{n+1}>0 A L_{n+1}>0 R L_{n+1}>0 A T_{n+1}>0 R T_{n+1}>0 C P_{n+1}>0$ 
ST 31. $A P_{n}>0 R P_{n}=0 A_{n}=0 R L_{n}=0 A T_{n}>0 R T_{n}=0 C P_{n}>0$

ANTEROGRADE REFRACTORY

$A P_{n+1}>0 R P_{n+1}=0 A L_{n+1}=0 R L_{n+1}=0 A T_{n+1}>0 R T_{n+1}=0 C P_{n+1}>0$

RETROCRADE

$A P_{n+1}>0 R P_{n+1}=100 A_{n+1}=0 R L_{n+1}=0 A T_{n+1}>0 R T_{n+1}=R R C_{n+1}>0$ $\mathrm{SP}+1=\mathrm{SP}: 33$

ST 32 $A P_{n}=0 R_{n}>0 A L_{n}=0 R_{n}=0 A T_{n}=0 R_{n}>0 C P_{n}>0$

MNTEROGRADE

$A P_{n+1}=1 R P_{n+1}>0 A L_{n+1}=0 R L_{n+1}=0 A T_{n+1}=A R P R T_{n+1}>0 C P_{n+1}>0$

$\mathrm{ST}_{\mathrm{n}+1}+\mathrm{ST} 33$

RETPOGRADE REFRACTORY

$A P_{n+1}=0 R P_{n+1}>0 A L_{n+1}=0 R_{n+1}=0 A T_{n+1}=0 R_{n+1}>0 C P_{n+1}>0$

ST 33. $A P_{n}>0 R P_{n}>0 A \mathbb{L}_{n}=0 R L_{n}=0 A T_{n}>0 R_{n}>0 C P_{n}>0$

ANTEROGRADE REPRACTORY

$A P_{n+1}>0 R P_{n+1}>0 A_{n+1}=0 R L_{n+1}=0 A T_{n+1}>0 R_{n+1}>0 C P_{n+1}>0$

RETROGRADE REPRACTORY

$A P_{n+1}>0 R P_{n+1}>0 A L_{n+1}=0 R L_{n+1}=0 A T_{n+1}>0 R_{n+1}>0 C P_{n+1}>0$

ST 34. AP $\mathrm{n}>0 \mathrm{RP}_{\mathrm{n}}>0 \mathrm{AL}_{\mathrm{n}}=0 \mathrm{RL}_{\mathrm{n}}>0 \mathrm{AT} \mathrm{T}_{\mathrm{n}}>0 \mathrm{RT} \mathrm{T}_{\mathrm{n}}>0 \mathrm{CP_{n }}>0$

ANTEROGRADE REFRACTORY

$A P_{n+1}>0 R P_{n+1}>0 A I_{n+1}=0 R L_{n+1}>0 A T_{n+1}>0 R T_{n+1}>0 C P_{n+1}>0$

RETROGRADE REFRACTORY

$A P_{n+1}>0 R P_{n+1}>0 A L_{n+1}=0 \mathrm{RL}_{n+1}>0 \mathrm{AT}_{\mathrm{n}}+1>0 \mathrm{RT}_{\mathrm{n}+1}>0 \mathrm{CP} \mathrm{P}_{\mathrm{n}}>0$ 
ST 35. $A P_{n}>0 R P_{n}>0 A L_{n}>0 R L_{n}=0 A T_{n}>0 R T_{n}>0 C P_{n}>0$

\section{ANTEROGRADE REFRACTORY}

\section{$\mathrm{AP}_{\mathrm{n}+1}>0 \mathrm{RP}_{\mathrm{n}+1}>0 \mathrm{AL}_{\mathrm{n}+1}>0 \mathrm{RL}_{\mathrm{n}+1}=0 \mathrm{AT}_{\mathrm{n}+1}>0 \mathrm{RT}_{\mathrm{n}+1}>0 \mathrm{CP} \mathrm{n}+1>0$ RETROGRADE REFRACTORY}

$A P_{n+1}>0 R_{n+1}>0 A_{n+1}>0 R L_{n+1}=0 A_{n+1}>0 R_{n+1}>0 \mathrm{CP}_{n+1}>0$ 


\section{References:}

Weyer Johann (Wierus)

Medicarum Observanonum Librill

Quoted from Collected Works, Amsterdam $917 \quad 1660$

Galen

Claudi Galeni Opera Omnia

ed Kulhn, Leipria 1828

Bijleveld WIJC, Wijnaendts van Resandt W, Wittert van Hoogland EBFF

Nederlands Adelsboek

Van Stockum en Zoon, "S-Gravenhage 2041916

\section{Hübotter $\mathrm{F}$}

Die chinesische Medizin zu Begim des XX lahrhunderts und hr historischer Entwicklungsgang.

Asia Major. Schindler, Leipzig 1929

\section{Scherf $\mathbb{D}$, schott $A$}

Extrasystoles and altied arrhythmias.

William Heinemann Medical Books Ltd London 1973

6 Wenckebach $\mathrm{KF}$

Zur Analyse des unregelmäsigen Pulses.

Z. klin Med. $36 \quad 1899$

\section{Einthoven W}

Over de beteekenis der electro physiologie als een onderdeel van de leer der levensverrichtingen.

E] Brin Leiden. The Netherlands:32 1906

\section{Einthoven W}

Le velecardiogramme.

Arch int Fhysiol. 4:132 1906

\section{$9 \quad$ Latour $\mathbf{H}$, Puech $\mathbf{P}$}

IElectrocardiographe Endocavitaire.

Masson Ed Pars 1957

\section{Durrer D, Schoo L, Schuilenburg RM, Wellens HJ}

The role of premature beats in the intiation and the fermination of supraventricular tachycardia in the Wolf-Parkinson- White syndrome

Circulation $36: 644 \quad 1967$

11 Damato AN, Lau SH, Helfant RH, Stein E, Patton RD, Scherlag BJ, Berkowitz WD

A sludy of heart Llock in man using this bundle recording

Circulation $39: 297 \quad 1959$

\section{Wellens HJ]}

Electrical stimulation of the heart in the study and treatment of tactiycardias.

Baltumore. Unwersity Park Press 1971

\section{Wellens HJ, Schuilenberg RM, Durrer D}

Electrical stimulation of the heart in patients with wentricular tachycardia

Circulation $46.216 \quad 1972$ 
Value and imitatione of programmed electrical stimulation of the heart in the study and treatment of tachycardias

George C Grimith Lecture

Crrculanion $57845 \quad 1976$

Comprehensive clmcal electrophysiogic studies in the investigation of documented or suspected tachyourding

Time Staff, Problems and Costs.

Circulation $61: 1010 \quad 1980$

\section{Berne RM}

Handbook of physiology

Section 2. The Cardiovascular System

Volume I The Heart

Williams \& Wikins Campany. Batimore :581 1979

\section{Mann JE, Sperelakis $\mathbb{N}$}

Further development of a model lor electrical transmission beween myocardial cells not connected by low-resistance pathways.

J Electrcard $12: 23 \quad 1979$

18 Salu $Y$

Computer simulation of electrical activity of the heart.

Itheor Biol. $43: 13 \quad 1974$

19 Moe GK, Rheinboldt WC, Abildskov IA

A computer model of atrial fibrillation.

Am Heart 167:200 1964

20 Sharp $\mathrm{GH}_{4}$ Joyner RW

Simulated propagation of cardiac action potentials.

Biopys I $31: 403 \quad 1980$

21 Liestol $\mathrm{K}$, Walloe L

A simulated sudy of a newron in a simple muscle control system.

Ack Physiol Scand 109 a6s 1980

\section{$22 \quad$ FitzHugh $\mathbb{R}$}

Impulses and physiological states in theoretical models of nerve membrane

Biophys ] [ 44451961

23 Owen E, Waring W, Shoji E, Prakash C

Digital simulation of the membrane voltage and cuments in nerwe and muscle fibers.

Comp Prog in Biomed 6.63 1976

24 Hodgkin AL, Huxley $\mathrm{AF}$

A cuantitative description of membrane cument and its application to conduction and excitation in nerve

J. Physiol $117,500 \quad 1952$

25 Capelle FIL w, Durrer D

Computer simulation of arthythmias in a network of coupled excitable elements.

Circulation fres $47: 454 \quad 1980$ 
A mathematical model of the slow-wave electrical actwity of the human small intestme

Med and Biol. Engineering. $12750 \quad 1974$

Pol B v d, Mark j VD

The heartbeat considered as a relaxation oscillation and an electrical model of he heart

Philos Mag Suppl 6:763 1928

Selvester RH, Collier C, Pearson R

Analog computer model of the vectorcardiogram.

Crrculation $31: 46 \quad 1965$

29 Selvester RH, Solomon JC, Gillespie TL

Digital computer model of a total body electrocardiographic surface map: Adul male torso simulation with lungs.

Circulation $38 ; 684 \quad 1968$

\section{Selvester RH, Kalaba R, Collier C, Belleman R, Kagiwada RH}

A digital computer model of the vectorcardiogram with distance and boundery elfects simulated myocardium inferction.

Mm Heart J $74: 899 \quad 1967$

\section{Min FBM}

Modelvorming van de electrische activiteit van maag en har mbv riet lineaure oscillatoren.

Rapport M126 University of Dellit 1973

32 Rosenberg RM, Chao $\mathrm{CH}_{0}$, Abbott I

A new mathematical model of electrical cardiac activity.

Math Biosciences 14:367 1.972

\section{Miller WT, Geselowitz DB}

Simulation studies of the electrocardiogram I. The nolmal heart.

Circulation Research $43: 301 \quad 1978$

\section{Miller WT, Geselowitz DB}

Simulation studies of the electrocardiogram II. Ischentia and infarction

Circulation Research $43.315 \quad 1978$

Hori M

Simulation study of QRS.'T waves based on an eccentric sphercal model of the heart.

Japarese Circulation ] $42: 5391978$

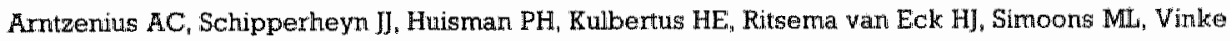
RVH

Model studies on activation of the heart.

Europ. J of Card 8:26! 1978

\section{Ritsema van Eck HJ}

Digital compuler simulation of cardiac excitation and repolarization in man

Thesis Dahousy University, Halifar, Nova Scotia, Canada 1972

\section{Rudy $\mathrm{X}$, Plonsey $\mathbf{R}$}

A. comparison of volume conduction and source geomeiry effects on body surface and epicardial potentials

Circulation Resecrch $46.983 \quad 1980$ 
The eccentric spheres model as the basis for a study of the role of geometry and inhompgenethes in electrocardiography

IEEE Trans Biomed Eng 26:392 1979

\section{Rudy $Y_{1}$ Plonsey $\mathcal{R}_{\text {, Liebman I }}$}

The effects of variations in conductwity and geometric parameters on the electrocardiogram, using an eccentic spheres model.

Circulation Research $44: 104 \quad 1979$

\section{Ramsey M, Barr RC, Spach MS}

Comparison of measured torso potentials with those simulated from epicardial potentials for ventricula depolarisation and repolarization in the intact dog.

Circulation Research $41: 660$ 197?

\section{Omura $Y$}

The relationshp between the transmembrane action potental and the voltage-lime-dependant negative resistance characteristics of the voltage-current curwes of excitable pacemaker and non pacemaker cell membranes.

Trang of the NY Acad of Sc. 33:467 1971

\section{Heethaar RM, Denier van der Gon JJ, Meyler FL}

$A$ mathematical model of A.V conduction in the rat heart.

Cardiovascular Research, 7:109 1973

44 Heethaar RM, De Vos Burchart RM, Denier van der Gon IJ, Meyler FL

A mathematical model of A-W conduction in the rat heart II, Quantification of concealed conduction. Cardiovascular Research, $7: 342 \quad 1973$

45. Heethaar RM, Denier van de Gon IJ, Meijler FL

Tnterpretation of some properties of AV Conduction with the help of analog smulation

Eur. J of Card 1:87 1973

46 Holley $\mathrm{L}$, Goodman AH, Richards DAB, Uther JB

Computer modelling of the ellectrical activation of the ventricular myocardium and re-entrant ventricular arrhythmias.

Austr NZJ Med in press 1982

47 Ross D, Dassen W, Vanagt E, Brugada P, Bär F, Wellens $H$

Cycle length alternation in circus movernent lachycardia using an atrioventricular accessory pathway. A study of the role of the Atrioventricular node using a computer model of tachycarclia.

Circulation $65.862 \quad 1982$

48 Dassen W, Rogs D, Brugada $P$, Bär $F$, Vanagt $E$, Wellens $H$

A computer model for the study of cycle length alternation during tachycardia.

Computers in Cardiohoy IEEE Conputer Society Silver Spring: $170 \quad 1980$

\section{Dassen W, Brugada P, Wellens H}

Shortening of the echo-interval with increasing prematurity: a computer model to study its value as differentialing criterion between reentry and triggered activity.

Computers in Cardiology JEEE Computer Society Silver Spring:303 1981

\section{Brugada P, Bar FWHM, Vanagt EJ, Wellens H]J}

Observations on mechenisms of circus movement tachycardia in the Wolf-Parkinson-White syndrome. Role of different tachycardia circuits and sites of block in maintenance of tachycardia.

Pace 4:507 1981 
51 Cooper TB, Hess RG, Litvin $Y_{\text {, }}$ Maclean WAH, Powell VG, Siler W, Stanley AWH and Waldrop SE A computer system ior electrophysiologic studies of cardiac rhythm in thumans.

Computers in Cardiology IEEE Computer Society Siver Spring:299 1981

52 Wellems HJ], Dulk K den, Brugada $\mathbb{P}$

Pacemaker management of cardiac amhythmas.

Cardiovascular Clinics in press 1983 


\section{Slotwoord}

Het werken met simulatiemodellen in de cardiologie is een fascinerende bezigheid.

Drie factoren maken de Capaciteitsgroep Cardiologie tot een unieke plaats om aan het onderzoek in de electrophysiologie mee te werken.

In de allereerste plaats de allomaanwezigheid van de stuwende kracht achter de afdeling: professor Hein Wellens. Zonder hem zou dit mathematisch onderzoek op een klinische afdeling nooit plaatsgevonden hebben. Een opsomming wat hij allemaal voor mij gedaan heeft is overbodig, hij weet hoezeer ik hem hiervoor dankbaar ben.

Op de tweede plaats de crew van het Electrophysiologisch Laboratorium. Deze afdeling die soms vanwege de vele buitenlandse research fellows wat weg heeft van het vreemdelingenlegioen vormt een continue broedstoof voor nieuwe ideeën en onderzoeken. Op deze groep moeten we trots maar ook heel zuinig zijn Hoewel heel riskant om namen te noemen wil ik toch drie mensen apart vernelden: Jet Beekman, Ton Gorgels en Pedro Brugada.

Op de laatste maar zeker niet minste plaats de leden van de Capaciteitsgroep Cardiologie. Ondanks het feit, dat het een van de snelstgroeiende groepen bimnen de universiteit is blijft het toch een hechte eenheid waarbinnen eenieder zijn eigen subspecialisme kan ontwikkelen. Het is een voorrecht binnen zo'n groep te mogen werken.

Op deze plaats zou ik graag promotor Prof Rob Heethaar, en de referenten Prof Harry Struyker Boudier, Frans van Capelle en David Ross van harte willen bedanken. Voor hun bijdrage aan de voorbereiding en de uiteindelijke vorm van dit proefschrift ben ik hen zeer dankbaar.

En op een voor partners van promovendi bekende laatse plaats zou ik Doortje willen danken voor al het geduld dat je met me hebt gehad als ik 's avonds weer zo nodig aan dit boekje moest gaan werken. Daarom zou ik graag dit boek aan jon op willen dragen.

Maastricht 10 maart 1983 


\section{Curriculum vitae}

De schrijver van dit proefschrift werd geboren op 13 januari 1953 te Maastricht. Zijn middelbare schoolopleiding(HBS-B) ontving hij aan het St Aloysius College te "s-Gravenhage van 1965 tot 1970. In dat zelfde jaar startte hij de studie Technische Informatica aan de Rheinisch-Westfalische Technische Hochschule te Aken WDL. Na het voltooien van zijn opleiding in 1976 was hij er gedurende bijna twee jaar werkzaam als wetenschappelik assistent. In 1977 volgde de terugkeer naar zijn oude moederstad en werd hij aangesteld als wetenschappelijk medewerker bij de Capaciteitsgroep Cardiologie waar het onderzoek dat leidde tot dif proefschrift werd vernicht. 
Layout: Chris Voskamp

mustraties: W R.M. Dassen

Druk: Schrijen-Lippertz bv 